Policy Research Working Paper 2305

The Impact of Banking Crises on Money Demand and Price Stability

Maria Soledad Martınez Peria

\author{
Policymakers in countries \\ undergoing bankıng crises \\ should not worry about the \\ structural stability of money \\ demand functions, the \\ behavior of money demand \\ durng crises can be modeled \\ by the same function used \\ during periods of tranquility \\ But policymakers should be \\ aware that in some instances \\ crises can give rise to variance \\ instability in the price or \\ inflation equations
}

The World Bank

Development Research Group

Finance

March 2000

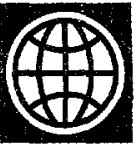


Policy Research Working PAPER 2305

\section{Summary findings}

Martinez Peria empirically investigates the monetary impact of banking crises in Chile, Colombia, Denmark, Japan, Kenya, Malaysia, and Uruguay. She uses cointegration analysis and error correction modeling to research:

- Whether money demand stability is threatened by banking crises.

- Whether crises bring about structural breaks in the relationship between monetary indicators and prices.
Overall, she finds no systematic evidence that basking crises cause money demand instability. Nor do the results consistently support the notion that the relationship between monetary indicators and prices undergoes structural breaks during crises. However, athougi: individual coefficients in price equations do not seen to be severely affected by crises, crises can sometines give rise to variance instability in price or inflation equations.

This paper - a product of Finance, Development Research Group - is part of a larger effort in the group to study banking crises. The study was funded by the Bank's Research Support Budget under the research project "Monetary Policy and Monetary Indicators during Banking Crises" (RPO 683-24). Copies of this paper are available free from the World Bank, 1818 H Street NW, Washington, DC 20433. Please contact Agnes Yaptenco, room MC3-446, telephone 202-473-1823, fax 202-522-1155, email address ayaptenco@worldbank.org. Policy Research Working Papers are also posted cri the Web at www.worldbank.org/research/workingpapers. The author may be contacted at mmartinezperia@worldbank.org. March. 2000. (81 pages)

The Policy Research Working Paper Series disseminates the findings of work in progress to encourage the exchange of ideas abun development issues. An objective of the series is to get the findings out quickly, even if the presentations are less than fully polished. The papers carry the names of the authors and should be cited accordingly. The findings, interpretations, and conchisions expressed in tibis paper are entirely those of the autbors. They do not necessarily represent the view of the World Bank, its Executive Direciors, or ibe countries they represent. 


\title{
The Impact of Banking Crises on Money Demand
}

\author{
and Price Stability
}

\author{
by \\ Maria Soledad Martinez Peria ${ }^{*}$ \\ The World Bank
}

\footnotetext{
* I am grateful for helpful discussions with Neil Ericsson, who consulted for the World Bank on this project. I am indebted to Tomas Baliño, Jerry Caprio, Patrick Honohan, David Marston, and Sergio Schmukler for very useful comments and suggestions. I would also like to thank Cristina Neagu and Ivanna Vladkova for excellent research assistance. All numerical results were obtained using PcGive Professional version 9.1; see Hendry and Doornik (1999). A similar version of this paper will be published in the International Monetary Fund Working Paper Series.

Address: 1818 H Street NW, Washington, DC 20433. Telephone: (202) 458-7341. Fax: (202) 522-2106. E-mail address: mmartinezperia@worldbank.org .
} 


\section{I - Introduction}

Banking crises have plagued countries around the world from Argentina to Zambia over the last two decades. In recent years, several papers have focused on identifying banking crisis episodes and studying their causes. ${ }^{1}$ However, until very recently, the importance of a sound banking sector for monetary policy implementation did not receive much attention. Two exceptions are the recent studies by Garcia-Herrero (1997) and Lindgren, Garcia, and Saal (1996). Both studies describe some of the distortions and problems that banking crises can create for the assessment and implementation of monetary policy. They argue that banking crises complicate the conduct of monetary policy because they destabilize money demand and money multipliers, they diminish the effectiveness of monetary instruments, and they affect the relationship between monetary indicators and prices. Ultimately, banking crises, they argue, may reduce the government's ability to achieve its inflation objective.

Monetary indicators refer to variables that help explain the behavior of prices and are monitored by policy-makers to guide them in the conduct of monetary policy. Also, these variables are typically included in the empirical equations for prices. Monetary aggregates are frequently used as monetary indicators. ${ }^{2}$ Central banks monitor the behavior and demand for monetary aggregates because they are reputed to be useful in explaining the behavior of prices. Furthermore, these variables are readily available to the monetary authorities at high frequencies, and they are considered to be better measured than other indicators.

\footnotetext{
${ }^{1}$ See Caprio and Klingebiel (1996), Demirguc-Kunt and Detragiache (1997), and Lingren, Garcia, and Saal (1996).

${ }^{2}$ Monetary aggregates have been traditionally used as targets for the conduct of monetary policy because they were thought to have a tightly controllable and reliable link to prices. Over time financial innovation and other factors have led central banks to abandon the use of monetary aggregates as strict targets for the conduct of monetary policy. Instead, monetary aggregates are increasingly being used as monetary indicators.
} 
Garcia-Herrero (1997) and Lindgren et al. (1996) argue that, because banking crises destabilize the demand for money, they are likely to affect the relationship between prices and monetary aggregates. Thus, they argue monetary authorities may benefit, in particular during crises, from expanding the set of indicators they monitor to include other indicators like exchange rates, interest rates, and stock prices. Though very informative, these studies rely heavily on a descriptive approach rather than on a systematic econometric evaluation of the problems that banking crises may bring. ${ }^{3}$

This paper conducts an empirical analysis of the monetary effects of banking crises. We research two issues. First, we evaluate the claim that money demand stability is threatened by the occurrence of banking crises. Secondly, we analyze the relationship between monetary indicators and prices and, in particular, we test whether crises cause a structural break in this relationship.

The study focuses on the following country and crises episodes: Chile (1981-87), Colombia (1982-1988), Denmark (1987-1992), Japan (1992-present), Kenya (1985-1989, 19921995), Malaysia (1985-1988), and Uruguay (1981-1985). ${ }^{4,5}$ These countries were chosen in order to obtain a geographically representative sample of countries that experienced banking problems over the last two decades. ${ }^{6}$

${ }^{3}$ Garcia-Herrero (1997) conducts a Johansen-type cointegration analysis to study long-run money demand stability, but she warns that her analysis is incomplete and that her sample is too short. Lindgren, Garcia, and Saal (1996) cite evidence found by Baliño and Sudararajan (1991) that broad money demand intercepts and interest elasticities change during banking crises in Argentina, Chile, Philippines, Spain, and Uruguay. However, Baliño and Sudararajan's analysis does not contemplate issues like cointegration and error correction modeling, so it is unclear whether the equations they base their results on are well specified.

${ }^{4}$ The dates in parentheses correspond to the periods identified by Caprio and Kinglebiel (1996) and Lindgren, Garcia, and Saal (1996) as periods of banking crises.

${ }^{5}$ Table A.1 in the appendix contains information on the causes, extent, and consequences of the crises we focus on.

${ }^{6}$ Though we started our investigation with a sample of 17 countries that experienced crises over the last two decades, data limitations reduced the number of countries included in the final analysis to the 7 mentioned above. 
In our empirical estimations, we use cointegration analysis and error correction modeling to find appropriate dynamic specifications for money and prices in each of the countries under study. Parameter constancy tests on the estimated money demand equations help us evaluate the hypothesis that money becomes unstable during periods of crisis. We focus on broad money since the demand for narrow money is more likely to be affected by issues such as financial innovation and deregulation, events that can themselves lead to instability. Finally, aside from examining which variables are significant indicators of the behavior of prices, we also perform parameter constancy tests to determine whether crises bring about a structural break in the relationship between prices and monetary indicators.

Overall, this paper does not find any systemic evidence that banking crises cause money demand instability. Regarding the determinants of prices, we find that money, exchange rates, foreign prices, and domestic interest rates are significant indicators of price behavior. Finally, the results do not support the notion that the relationship between monetary indicators and prices undergoes a structural break during these episodes. However, for three out of the seven countries in this study, there is evidence of variance instability in the price equations as a result of banking crises.

The rest of the paper is organized as follows. Section II briefly reviews the relevant literature. Section III outlines the empirical methodology used in this paper. Section IV presents the empirical results. Finally, section V concludes.

\section{II - Literature Review}

A number of papers have studied the demand for money and the determinants of inflation in the countries included in this paper. Table A.2 in the appendix summarizes most of these 
papers. These studies help guide the construction of the money demand and price/inflation specifications. Wherever possible and appropriate, we try to use the same measures of the "own" and "outside" rates of money for each country and to include most of the variables found to be significant in previous studies. ${ }^{7}$ However, the majority of these papers cover different sample than we do, and also they do not explicitly examine the impact of banking crises on the stability of money demand.

The modeling and empirical approach used to estimate the demand for money in this study resembles that of Baba, Hendry, and Starr (1992), Ericsson, Hendry, and Prestwich (1998), and Ericsson and Sharma (1998). These papers focus on different countries and are not concerned with the impact of banking crises on money demand. However, we follow these papers in their treatment of issues like cointegration, error correction modeling, and parameter constancy.

There is a vast empirical literature on the "information content" (i.e., ability to explain prices) of monetary indicators that is related to the analysis conducted in this paper. ${ }^{8}$ Most of these studies evaluate the information content of monetary indicators by estimating vector autoregressive models (VARs) of prices, monetary aggregates, and other potential monetary indicators and by conducting F-exclusion tests to determine the marginal explanatory power of each indicator in explaining prices. This literature has mostly focused on the case of the U.S. and other developed countries. ${ }^{9}$ Furthermore, to our knowledge, the existing literature has not

\footnotetext{
${ }^{7}$ The "own" return on money (M2 in this paper) typically refers to the average rate on deposits included in M2. The "outside" rate of money refers to the average rate on some alternative asset not included in M2 (typically T-bills or government bonds).

${ }^{8}$ See Baumgartner and Ramaswamy (1996), Baumgartner, Ramaswamy, Zettergren (1997), Caramazza and Slawner (1991), Davis and Henry (1994), Friedman and Kuttner (1992), Hamann (1993), Hostland, Poloz, and Storer (1987), Mahdavi and Zhou (1997), Sims (1980), Stock and Watson (1989), among others.

${ }^{9}$ Hannan (1993) is an exception. This study examines the relationship between money, output, and prices
} 
empirically analyzed the impact of banking crises on the relationship between prices and indicators.

The problem with the studies that focus primarily on the information content of monetary indicators is that changes in their explanatory power may be caused by increases in their volatility or noisiness over certain samples. Also, changes in the degrees of freedom in the estimation of the price equation can also affect the results. For example, a preliminary analysis we conducted indicates that the explanatory power of most monetary indicators, including money, drops during crisis periods, relative to tranquil periods. ${ }^{10}$ However, the lack of statistical significance of certain variables may very well be due to the loss of degrees of freedom over the much shorter crisis periods.

This paper improves and adapts the methodology on the information content of monetary indicators described above, in order to study the impact of banking crises on the relationship between prices and indicators. Instead of focusing on examining the explanatory power of certain variables over different samples, this paper tests for potential structural breaks in the relationship between prices and monetary indicators. Structural stability is a more relevant matter for policymakers than the issue of whether a given variable happens to be statistically significant over a particular sample. As long as the pre-crisis price equation remains stable over the crisis periods, policy-makers can continue to use this formulation to model prices.

This study also pays substantial attention to the issue of cointegration (i.e., the potential long-run relationship between prices and monetary indicators), which has been ignored by most studies on the information content of monetary indicators. Finally, aside from modeling prices as a function of domestic monetary and financial variables only (as most studies do), following De

\footnotetext{
in a group of Pacific Basin countries that underwent a process of financial liberalization during the 1980s.

${ }^{10}$ Results are available upon request.
} 
Brouwer and Ericsson (1998) and Juselius (1992), we also control for the potential impact of wages, unemployment, and external factors on prices.

\section{III - Empirical Methodology and Data}

To examine the monetary impact of banking crises, we estimate dynamic money demand and price/inflation equations using monthly data for each country for the period $1975-1998 .{ }^{11}$ The purpose of estimating these equations is twofold. First, we want to determine whether money demand becomes unstable during banking crises. Secondly, we want to test whether crises cause a structural break in the relationship between monetary indicators and prices.

A number of steps are involved in the empirical analysis and testing of the issues discussed above. First, we conduct unit root tests to determine whether the variables included in the empirical analysis are stationary (see section III.1). Second, we test for cointegration between prices and the monetary, labor, and external factors determining prices (see section III.2). Third, we obtain single equation error correction models for money and prices (see section III.3). Finally, we conduct parameter constancy tests to examine the stability of the money demand and price/inflation equations (section III.4).

\section{1 Testing the presence of unit roots}

Standard inference procedures do not apply to regressions that contain non-stationary series. Therefore, for each country, we conduct augmented Dickey-Fuller (1981) unit root tests to evaluate whether the variables used in our empirical analysis are stationary.

Given a series

\footnotetext{
11 The sample for individual countries might be smaller than 1975-1998 depending on data availability. See the data appendix.
} 
$y_{t}=\mu+\beta y_{t-1}+\varepsilon$

where $\mu$ and $\beta$ are parameters and $\varepsilon_{t}$ is assumed to be white noise. $y_{t}$ is stationary if $-1<\beta<1$. The augmented Dickey-Fuller test to determine if $y_{t}$ is non-stationary is carried out by estimating an equation with $y_{t-1}$ subtracted from both sides of the equation and adding lagged difference terms to control for higher order correlation in the series.

$\Delta y_{t}=\mu+(\beta-1) y_{t-1}+\delta_{1} \Delta y_{t-1}+\delta_{2} \Delta y_{t-2}+\ldots+\delta_{p-1} \Delta y_{t-p+1}+\varepsilon$

This augmented specification is then used to test whether $\beta-1=0$ against the alternative that $\beta$ $1<0$. Dickey and Fuller (1981) have determined the distribution and the critical values for this test. Finally, non-stationary variables are differenced as many times as needed (depending on the variables' order of integration) until stationary is achieved.

\section{2 Testing cointegration}

Following Juselius (1992), we model domestic prices in each of the countries in our sample as a function of monetary, external, and cost push factors. In other words, we assume that consumer price inflation can be associated with inflation in the labor markets, that is wages being above the underlying steady-state level; with monetary inflation, that is, excess money, and with imported inflation.

For each country, we conduct Johansen (1988) cointegration tests to determine whether there exist any long-run equilibrium relationships in the monetary, labor, and external sectors. Given a vector autoregressive system (VAR) of order p:

$y_{t}=A_{1} y_{t-1}+\ldots+A_{p} y_{t-p}+u_{t}$ 
where $y_{t}$ is a $\mathrm{k}$-vector of non-stationary $\mathrm{I}(1)$ variables and $\mathrm{u}_{\mathrm{t}}$ is a vector of innovations. The VAR can be re-written as:

$$
\Delta y_{i}=\Pi y_{1-1}+\sum_{i=1}^{p-1} \Gamma_{i} \Delta y_{t}-i+u_{t}
$$

where

$$
\Pi=\sum_{i=1}^{p} A_{i}-I \quad \Gamma i=-\sum_{j=i+1}^{p} A_{j}
$$

According to Granger's representation theorem, if the coefficient matrix $\Pi$ has rank $r<k$, then there exist $\mathrm{kxr}$ matrices $\alpha$ and $\beta$ each with rank $\mathrm{r}$ such that $\Pi=\alpha \beta^{\prime}$ and $\beta^{\prime} y_{\mathrm{t}}$ is stationary. $\mathrm{r}$ determines the number of cointegrating relations (the cointegrating rank). Each column of $\beta$ is a cointegrating vector. The elements of $\alpha$ are referred to as the adjustment parameters in the vector error correction model.

Johansen's test of cointegration consists of estimating the $\Pi$ matrix in an unrestricted form and testing whether we can reject the restriction implied by the reduced rank of $\Pi$. If there are $\mathrm{k}$ endogenous variables, with one unit root each, there can be from zero to $\mathrm{k}-1$ linearly independent, cointegrating relations. The trace and maximal-eigenvalue statistics are used to test the number of cointegrating vectors. ${ }^{12}$

The distribution of the cointegration tests is affected by the assumptions made about the deterministic parts of the model. In other words, the distribution of the test depends on whether we allow for a trend and/or constant term (see Johansen and Juselius (1990), and Johansen

${ }^{12} \eta_{r}=-T \sum_{i=r+1}^{k} \log \left(1-\lambda_{i}\right)$ is the trace statistic and $\xi_{r}=-T \log \left(1-\lambda_{r+1}\right)$ refers to the maximal eigenvalue statistic. In both cases, $\mathrm{r}=0,1,2 . . \mathrm{k}-2, \mathrm{k}-1$. 
(1994)). In this paper, the constant and seasonals enter unrestrictedly in the VAR. Also, we allow for a linear trend in the cointegration space. ${ }^{13}$

As in Juselius (1992), we conduct the cointegration analysis in each sector (monetary, labor, and external) separately, rather than examining cointegration among all possible determinants of inflation for a number of reasons. In the first place, the data sample is not large enough to examine systems including as many as ten variables. Secondly, as indicated by Juselius (1992. p406) "a drawback of the analysis of the multivariate cointegration model is that the difficulties of interpreting the cointegration space grow when more variables are added to the VAR system."

\section{III.2.a Cointegration testing in the monetary sector}

We test for cointegration among the variables in the vector $Z_{t}^{1}=\left\{\mathrm{m}, \mathrm{p}, \mathrm{y}, \mathrm{I}^{\mathrm{o}}, \mathrm{I}^{\mathrm{a}}, \Delta \mathrm{p}, \mathrm{t}\right\}$ where $\mathrm{m}$ is the logarithm of nominal or real M2 (depending on the order of integration of M2), $\mathrm{y}$ is the logarithm of a measure of income (usually industrial production measured in logarithms), $\mathrm{I}^{\circ}$ is the level of the own rate of return on M2 (in most cases an average deposit rate), $\mathrm{I}^{\mathrm{a}}$ is the level of a measure of the return on alternative assets outside from M2 (e.g., government bonds or bills), and $t$ is a time trend. In those cases where there is evidence that money is $I(1)$, we exclude inflation, $\Delta \mathrm{p}$ (defined as the change in the logarithm of prices), since this variable will be stationary.

\footnotetext{
${ }^{13}$ We include a trend in the cointegration space in order to obtain a test for cointegration invariant to the value of the constant term (see Johansen (1995)). Also, we restrict the trend to the cointegration space since we typically do not think that growth rates are quadratic, which they could be if the trend entered unrestrictedly.
} 


\section{III.2.b Cointegration testing in the labor/wage sector}

If wages and prices are I(1), we test for cointegration between the variables in the vector $Z^{2 a}{ }_{t}=\{w, u, p, t\}$. In this case, $w$ corresponds to the logarithm of nominal wages, $u$ is the log of the unemployment rate, and $\mathrm{p}$ is the $\log$ of prices. Once again, $\mathrm{t}$ is a time trend. For the countries where prices and wages are I(2), we obtain an I(1) representation by examining cointegration among the following variables $Z^{2 b}{ }_{t}=\{w-p, u, \Delta p, t\}$ where $w-p$ is the real wage (defined as the log of wages minus the $\log$ of prices) and $\Delta \mathrm{p}$ is, once again, the inflation rate.

\section{III.2.c Cointegration testing in the external sector}

If domestic and foreign prices are I(1), we test for cointegration among the vector of variables $Z_{t}^{3 a}{ }_{t}=\left\{p, e, p^{*}, I, I^{*}, t\right\}$. In this case, $p$ corresponds to the logarithm of domestic prices, e is the log of the exchange rate with respect to the dollar or deutsche mark depending on the country, $\mathrm{p}^{*}$ is the logarithm of the foreign price level (represented by the U.S. or German price level depending on the country), $\mathrm{I}$ is the domestic interest rate, and $\mathrm{I}^{*}$ is the corresponding foreign (U.S. or German) interest rate. ${ }^{14}$ Following Juselius (1992), we include interest rates in the cointegration analysis, because the determination of exchange rates takes place in both the goods and capital markets. Therefore, we need to account for the interaction between them to understand the external effects on prices.

When there is evidence that domestic prices could be $I(2)$, we examine cointegration

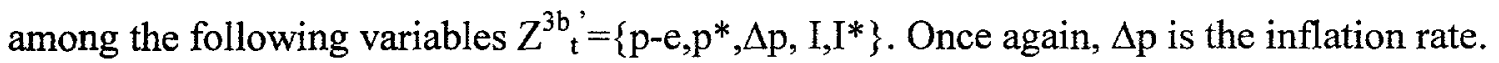

\footnotetext{
${ }^{14}$ For Chile, Colombia, Japan, Kenya, Malaysia, and Uruguay, the exchange rate used is that of each country's domestic currency vis-à-vis the dollar. Also, for these countries the relevant foreign price level is the U.S. price level, and the foreign interest rate is the rate on U.S. government t-bills. In the case of Denmark, we use the krone/deutsche mark rate, German prices are the relevant foreign prices, and we use the interest rate on German government bonds as the relevant foreign interest rate. The exchange rate is expressed as domestic currency per unit of foreign currency.
} 


\section{3 Single equation error correction modeling}

After testing for cointegration in the monetary sector, we develop an error correction model (ECM) for money for each country in our sample. The conditional ECM for money is of the form:

$\Delta m_{t}=c+\sum_{i=1}^{k-1} \gamma_{1 i} \Delta m_{t-i}+\sum_{i=0}^{k-1} \gamma_{2 i} \Delta p_{t-i}+\sum_{i=0}^{k-1} \gamma_{3 i} \Delta y_{t-i}+\sum_{i=0}^{k-1} \gamma_{4 i} \Delta I_{t-i}^{O}+\sum_{i=0}^{k-1} \gamma_{5 i} \Delta I_{t-i}^{A}+\sum_{i=0}^{k-1} \gamma_{6 i} \Delta e_{t-i}+\lambda_{1}{ }^{\prime} E C M m o n e y_{t-1}+\omega_{t}$

where $\omega_{\mathrm{t}}$ is a white noise error term. ECMmoney refers to the cointegrating vectors found (if any) for the monetary sector. The remaining variables have been defined above. For those countries where there is evidence that money and prices are $\mathrm{I}(2), \Delta \mathrm{m}$ is replaced by $\Delta(\mathrm{m}-\mathrm{p})$ and $\Delta \mathrm{p}$ is replaced by $\Delta \Delta \mathrm{p}$, the second difference of prices.

Similarly, we develop an ECM to analyze the short-run and long-run determinants of prices/inflation. This ECM model incorporates the cointegrating vectors found for the monetary (ECMmoney), labor (ECMwages), and external sectors (ECMexternal). The ECM for prices is of the form:

$$
\begin{aligned}
& \Delta p_{t}=c+\sum_{i=1}^{k-1} \pi_{1 i} \Delta p_{t-i}+\sum_{i=1}^{k-1} \pi_{2 i} \Delta m_{t-i}+\sum_{i=0}^{k-1} \pi_{3 i} \Delta y_{t-i}+\sum_{i=0}^{k-1} \pi_{4 i} \Delta I_{t-1}^{o}+\sum_{i=0}^{k-1} \pi_{5 i} \Delta I_{t-1}^{a}+\sum_{i=0}^{k-1} \pi_{6 i} \Delta w_{t-i}+ \\
& \sum_{i=0}^{k-1} \pi_{7 i} \Delta u_{t-i}+\sum_{i=0}^{k-1} \pi_{8 i} \Delta e_{t-i}+\sum_{i=0}^{k-1} \pi_{9 i} \Delta p_{t-1}^{*}+\sum_{i=0}^{k-1} \pi_{10 i} \Delta I_{t-1}^{*}+\sum_{i=0}^{k-1} \pi_{11 i} \Delta s p_{t-1}+ \\
& \alpha_{1}^{*} \text { ECMmoney }_{t-1}+\alpha_{2} * \text { ECM }_{\text {wages } t-1}+\alpha_{3} * \text { ECMexternal }_{r-1}+v t
\end{aligned}
$$

where $v_{t}$ is a white noise error term and the majority of the remaining variables are defined above. $\Delta$ sp refers to the change in stock prices. In those cases where money, prices, and wages are I(2), the first differences of these variables $\left(\Delta \mathrm{m}_{\mathrm{t}}, \Delta \mathrm{p}_{\mathrm{t}}\right.$, and $\left.\Delta \mathrm{w}_{\mathrm{t}}\right)$ are replaced by their second differences $\left(\Delta \Delta \mathrm{m}_{\mathrm{t}}, \Delta \Delta \mathrm{p}_{\mathrm{t}}\right.$, and $\Delta \Delta \mathrm{w}_{\mathrm{t}}$ respectively). 
After estimating the ECM equations for money and prices, we reduce these models to obtain parsimonious representations. In other words, we exclude all insignificant variables and lags. At each stage, we conduct F-tests to compare the previous model with the latest reduced version of the model, in order to verify that the restrictions implied by the reduced model are indeed accepted. $^{15}$

\section{4 Testing parameter constancy}

We examine the stability of the single equations for money and prices in a number of ways. First, we perform Hansen (1992) tests for individual coefficient, variance, and joint (error variance and coefficients) stability. In general, these tests may have low power because the break-point is unknown. ${ }^{16}$ Secondly, we present sequentially estimated one-period ahead and break-point Chow (1960) statistics. Third, to test whether the instability arises explicitly from the crisis period, we report a Chow-type F-test, which we label F-CRISIS. This test compares the equations estimated over the whole sample (i.e., the sample including the crisis and tranquil periods) with the estimates for the period excluding the banking crisis. Finally, we interact the regressors in the price equation with a dummy that equals one during crisis periods (and zero otherwise) and we test whether these interaction terms are significant. The purpose of these regressions is to study whether the relationship between prices and individual monetary indicators is disrupted by crises.

\footnotetext{
${ }^{15}$ These tests are available upon request.

${ }^{16}$ See Hansen (1992).
} 


\section{5 The data}

Monthly data on monetary aggregates, financial variables (like exchange rates and interest rates) come from national sources (e.g., central bank bulletins, ministry of finance reports, etc.) and international sources (IMF and OECD databases). Wherever possible, we also control for the role of wages, the unemployment rate, and external factors (like foreign prices and interest rates) in explaining prices. These variables come from the same sources mentioned above. For all countries, we try to cover the period closest to January 1975 - June 1998 . A data appendix, at the end of the paper, describes the data used, the corresponding sources, and the relevant sample periods for each country in our study.

\section{IV - Empirical results}

\section{IV.1. Unit root tests}

Because this study includes a significant number of countries and variables, we do not discuss the unit root test results in detail here. However, Table A.3 in the appendix presents the augmented Dickey-Fuller (ADF) statistics, for each variable, in each country, in the sample. Every ADF statistic is reported for the shortest lag length obtainable without dropping a lagged difference significant at the $5 \%$ level.

For all countries, the hypothesis of a unit root cannot be rejected for any of the nominal variables in levels. Interest rates, output, the unemployment rate, and the change in the exchange rate appear to be unequivocally $\mathrm{I}(1)$ in most countries. Also, in general, prices, $\mathrm{M} 2$, and wages seem to be I(1). However, for Chile, Denmark, Malaysia, and Uruguay there is some evidence that these variables may be I(2). In particular, for these countries, either the Dickey-Fuller tests accept the hypothesis of a unit root at the chosen lag length (or at surrounding lags), or the 
estimated coefficient on the lag of the variable is close to one for the chosen lag length (or for lags surrounding it).

Given the unit root test results, we conduct the cointegration analysis assuming that all variables (in levels or log levels) are I(1) first. For countries were the evidence is mixed, we also try an $I(2)$ approach. By an $I(2)$ approach, we mean that we transform the supposedly $I(2)$ variables to obtain an I(1) representation before conducting the cointegration analysis (see Johansen 1995). For example, in the cointegration analysis for money, if money and prices are I(2), an I(1) representation implies examining cointegration between $\mathrm{m}-\mathrm{p}$ and $\Delta \mathrm{p}$, along with other I(1) variables (typically interest rates). For each country, we report the results from the approach that yields the most sensible results, given economic theory.

\section{IV.2. Cointegration results}

As discussed in the previous section, we use Johansen's (1988) procedure to conduct the cointegration analysis for each sector, in each country. We determine the lag length of the system used to perform the cointegration analysis by estimating a regular VAR (starting at 14 lags or 13 lags depending on whether variables are $\mathrm{I}(1)$ or $\mathrm{I}(2)$ ) and sequentially reducing the model until the F-test for the last lag of all remaining variables reject further reduction. ${ }^{17}$

Below, we discuss the cointegration results for all countries, by sector affecting prices. First, we display the results for the monetary sector (section IV.2.a ). Secondly, we present the results obtained for the labor sector (section IV.2.b). Finally, we report the results for the external sector (section IV.2.c).

\footnotetext{
${ }^{17}$ The results from these tests are available upon request.
} 


\section{IV.2.a. Cointegration results for the monetary sector}

The cointegration results for money are shown in Table 1. This table indicates the rank of the system chosen, the names given to the cointegrating vectors found, and the coefficients for the cointegrating vectors. We report the lag of the system chosen, the actual trace and maximum eigenvalue statistics, and the corresponding critical values in Table A.4 in the appendix.

For Chile, Denmark, Japan, Malaysia, and Uruguay, we pursue an I(2) approach. In other words, because we found some evidence that money and prices are I(2) in these countries, we transform these variables to obtain an I(1) representation suitable to test for cointegration (see Johansen 1995). Thus, we examine the cointegration between real money (m-p), income (y), inflation $(\Delta \mathrm{p})$, the own rate of return on money $\left(\mathrm{I}^{\mathrm{o}}\right)$, and its domestic alternative or outside return $\left(\mathrm{I}^{\mathrm{a}}\right) .{ }^{18,19}$

For all five countries mentioned above, we find at least one cointegrating vector that has a long-run real money demand interpretation. We find that inflation always has a negative impact on real money demand as expected, and income has a unit elasticity. The own rate of return on money (i.e., the average deposit rate) is positive and significant in the equations for Denmark, Japan, and Uruguay. Furthermore, the own and outside rates of return on money have opposite and equal effects for Japan and Denmark. ${ }^{20,21}$ For Chile and Malaysia, interest rates do not affect money demand.

\footnotetext{
${ }^{18}$ Initially, given the unit root results, we assumed all variables to be $I(1)$ and we tested for cointegration between $\mathrm{m}, \mathrm{p}, \mathrm{y}, \mathrm{I}^{\mathrm{o}}$, and $\mathrm{I}^{\mathrm{a}}$. However, for these countries this approach was unsuccessful (the results are available upon request). Also, given that from the unit root tests there was some evidence that prices, money, and wages are I(2), we decided to test for cointegration using an I(2) approach.

${ }^{19}$ The exact definition of the return for money and the outside rate of return for each country is in the data appendix.

${ }^{20}$ Following Juselius (1998), we allow a dummy that captures the period after the withdrawal of capital controls in Denmark to enter the cointegration space. This dummy is significant in the cointegration vector for money demand, indicating that money demand fell following the banning of controls.

${ }^{21}$ For Chile, Colombia, and Uruguay, we do not include the rate of return outside of money from the
} 
Aside from a long-run relationship for real money, for Chile, Denmark, and Malaysia, we also find evidence of the existence of other cointegrating vectors. For Chile, the second vector indicates that income is stationary around a trend, while the third vector suggests that the deposit rate is stationary. For Denmark, the Johansen procedure points to a rank 2 system. The second cointegrating vector for Denmark reflects a positive relationship between inflation, output, and interest rates spreads. For Malaysia, aside from the money vector, we also find that income, the own rate of return on money, and the outside rate are each stationary around a trend.

For Colombia and Kenya, where the Dickey-Fuller tests indicated that prices and money are $\mathrm{I}(1)$, we test for cointegration between nominal M2 (m), prices (p), the own rate of return on money $\left(I^{0}\right)$, and its alternative return $\left(I^{a}\right)$. We find that for these countries at least one cointegrating vector can be interpreted as a long-run money demand equation. We can also accept price homogeneity and unit income elasticities for these countries. For Colombia, interest rates do not seem to enter the long-run equation, while in Kenya we find that the outside or alternative rate of return on money has a negative impact on money demand.

For Colombia, we also find a second vector that specifies that the own return on money is trend stationary, For Kenya, we find two extra vectors, aside from the money demand vector. The second vector indicates a relationship between output, the outside interest rate, and a trend. The final vector shows that the spread between the own and outside rates of return on money is stationary around a trend.

Summarizing, the fact that we find evidence of cointegration in the monetary sector of all countries, even though these countries underwent banking crises at some point in the sample, indicates that the long-run stability of money demand is not threatened by these episodes.

cointegration equations since there was no consistent measure for these countries for the full sample period. 


\section{IV.2.b. Cointegration results for the labor/wage sector}

Table 2 reports the cointegration results for the labor/wage sector for all countries. In the case of Chile, Denmark, Japan, and Uruguay, given that we found some evidence that prices and wages are $I(2)$, we test for cointegration between real wages $(w-p)$, inflation $(\Delta p)$, and the unemployment rate $(\mathrm{u})$.

For each of the four countries mentioned above, we find evidence of one cointegrating vector with a long-run real wage interpretation. For Chile, Denmark, and Uruguay, we find that inflation and the unemployment rate negatively affect real wages. In the case of Japan, aside from testing cointegration between $w-p, \Delta p$, and $u$, we also include a dummy for July and June 1997 interacted by a trend. These variables aim to control for bonus payments paid in June during the early part of the sample and later in July of each year. We find one cointegrating vector where real wages are negatively affected by inflation. The unemployment rate does not seem to enter this relation.

For Colombia, we test for cointegration between nominal wages, prices, and the unemployment rate, given that we concluded from the unit root tests that prices and wages in Colombia are I(1). We find that wages are positively affected by prices, but the unemployment rate does not appear to play a significant role.

Finally, we do not report results for Kenya and Malaysia, because high frequency wage data is not available for these countries, for the period under consideration.

\section{IV.2.c. Cointegration results for the external sector}

Table 3 presents the cointegration results for the external sector. For Chile, Denmark, Japan, Malaysia, and Uruguay, where we found evidence that prices could be $I(2)$, we use the 
Johansen technique to test for cointegration between domestic prices expressed in foreign currency $(\mathrm{p}-\mathrm{e})$, foreign prices $\left(\mathrm{p}^{*}\right)$, inflation $(\Delta \mathrm{p})$, the domestic interest rate $(\mathrm{I})$, and the foreign interest rate $\left(\mathrm{I}^{*}\right) .^{22}$ For Colombia and Kenya, we pursue an $\mathrm{I}(1)$ approach instead. Thus, we test for cointegration between domestic prices $(p)$, the dollar exchange rate (e), foreign prices $\left(\mathrm{p}^{*}\right)$, the domestic interest rate $(I)$, and the foreign interest rate $\left(I^{*}\right)$. Foreign prices $\left(\mathrm{p}^{*}\right)$ refer to U.S. dollar prices in the case of Chile, Colombia, Japan, Kenya, Malaysia, and Uruguay. Also, for these countries, the exchange rate is the domestic currency rate vis-à-vis the dollar and foreign interest rates refer to the return on dollar assets (typically T-bills). For Denmark, foreign prices are German prices, the foreign interest rate is the rate on deutsche mark denominated assets, and the exchange rate is the krone/deutsche mark exchange rate.

For Chile, Denmark, Japan, Malaysia, and Uruguay, where the empirical evidence indicates that prices are $I(2)$, we find at least one cointegrating vector that has a purchasing power parity (PPP) interpretation including a dynamic term, $\Delta \mathrm{p}^{23}$ Furthermore, in the case of Denmark, Japan, and Uruguay, there is evidence of a second vector that can be interpreted as an uncovered interest rate parity (UIP) relationship, given that $\Delta \mathrm{p}=\Delta \mathrm{e}^{24}$

\footnotetext{
${ }^{22}$ For Chile, Denmark, Japan, Malaysia, and Uruguay we test for cointegration between $p-e, \Delta p, p^{*}, i$, and $i^{*}$, given that for these countries we found evidence that $p$ is $I(2)$. In general, we find a cointegrating vector between $\mathrm{p}-\mathrm{e}, \mathrm{p}^{*}$ and $\Delta \mathrm{p}$. This is evidence that $\mathrm{p}$ is $\mathrm{I}(2)$. Also, this suggests that e or $\mathrm{p}^{*}$ are $\mathrm{I}(2)$. In general, we do not think $\mathrm{p}^{*}$ (German or U.S. prices) is $\mathrm{I}(2)$. We tested for cointegration assuming $\mathrm{p}^{*}$ to be $\mathrm{I}(2)$, but the attempt was mostly unsuccessful. The only other possibility is that $\mathrm{e}$ is $\mathrm{I}(2)$. The main problem with this interpretation is that the Dickey-Fuller tests do not point to e being I(2). A possible explanation for this seemingly contradictory evidence is that $\Delta \mathrm{e}$ is $\mathrm{I}(1)$, but it has a large $I(0)$ component on top of it. Thus, when we look at it as a univariate process all we see is white noise. However, when it comes to system analysis, it could be that $\mathrm{p}$ and e have matching $\mathrm{I}(2)$ components that cancel out and that may explain why we find cointegration between these variables.

${ }^{23}$ In the case of Chile, we test for cointegration between $\mathrm{p}-\mathrm{e}, \mathrm{e}, \Delta \mathrm{p}$, and $\mathrm{p}^{*}$. We do not include interest rates, because the money demand cointegration analysis suggested that the Chilean interest rate is stationary.

${ }^{24}$ If $\mathrm{p}$ and $\mathrm{e}$ are $\mathrm{I}(2)$ and $\mathrm{p}$-e is $\mathrm{I}(1)$, then $\Delta \mathrm{p}$ and $\Delta \mathrm{e}$ are each $\mathrm{I}(1)$, but $\Delta \mathrm{p}=\Delta \mathrm{e}+\mathrm{I}(0)$.
} 
As mentioned above, for Colombia and Kenya, we examine cointegration between p, e, $\mathrm{p}^{*}, \mathrm{I}$, and $\mathrm{I}^{*}$, since $\mathrm{p}$ and $\mathrm{e}$ appear to be $\mathrm{I}(1)$ in these countries. For Colombia, we find evidence of three cointegrating vectors. The first vector has a PPP interpretation. The last two vectors indicate that $I$ and $I^{*}$ are stationary. For Kenya, we find two cointegrating vectors. The first vector is a combination of a PPP relationship and the I-I* spread. The second vector indicates that the spread between I and I* is trend stationary.

\section{IV.3. Reduced single equation money demand results:}

\section{Is the stability of money demand affected by banking crises?}

In this section, we present and discuss the results for the parsimonious, conditional, single-equation model for broad money demand for each country in our sample. The main purpose of this section is to test the constancy of broad money demand. In other words, we want to test whether countries that have experienced banking crises are likely to exhibit non-constant broad money demand functions.

Tables 4 to 10 report the estimated coefficients, standard errors, and test statistics for the reduced and final money demand equations for Chile, Colombia, Denmark, Japan, Kenya, Malaysia, and Uruguay, respectively. For all countries with the exception of Japan, we include the change in the exchange rate $(\Delta \mathrm{e})$ as a regressor in the single equation for money. ${ }^{25}$ We introduce this variable to control for the possibility of flight to foreign currency in countries were there are not a lot of competing assets relative to bank deposits, and/ or where the exchange rate has been traditionally pegged to a foreign currency. ${ }^{26}$

\footnotetext{
${ }^{25}$ With the exception of Denmark, where we use the krone/deutsche mark exchange rate, for all other countries the exchange rate variable refers to the domestic currency rate with respect to the dollar.

${ }^{26} \mathrm{We}$ did not include the change in the exchange rate in the cointegration analysis, because we found this variable to be $\mathrm{I}(0)$ for all countries according to the Dickey Fuller tests.
} 
For Colombia and Kenya, where money and prices appear to be I(1), inflation is not significant. We find that in all remaining countries, inflation, $\Delta \mathrm{p}$ (or the change in inflation $(\Delta \Delta \mathrm{p}$ or $\Delta^{2} \mathrm{p}$ ) depending on the country), is significant and has a negative effect on the demand for real money.

With the exception of Japan, changes in income (y) have a positive effect on the demand for money. However, income is significant only in the equations for Chile and Malaysia.

The own rate of return on $\mathrm{M} 2, \mathrm{I}^{\circ}$ (typically the average deposit rate), has a positive and significant impact on the demand for broad money in Chile, Kenya, and Uruguay. This variable is positive but insignificant for Colombia and Japan, and negative but insignificant in Denmark, and Malaysia. Changes in the outside or alternative rate of return on money, $\mathrm{I}^{\mathrm{a}}$, have a significant negative impact on money demand in Denmark and Kenya. However, this variable is insignificant in the equations for Japan and Malaysia.

Exchange rate changes are mostly significant and have a negative impact on the demand for broad money in Colombia, Denmark, and Kenya. ${ }^{27}$ In the case of Uruguay, the exchange rate has both a positive and negative impact on broad money, depending on the lag length. However, the overall effect is zero. The exchange rate is not significant in Chile and Malaysia. Finally, the error correction terms associated with long-run money demand are significant and negative in the dynamic money demand equations for all countries.

Tables 4 to 10 , also present various diagnostic statistics, which show that the final equations obtained are well specified. These diagnostics statistics are tests against various alternative hypotheses: residual autocorrelation (AR), skewness and excess kurtosis (normality), autoregressive conditional heteroskedasticity $(\mathrm{ARCH})$, and heteroscedasticity (hetero). The null

\footnotetext{
${ }^{27}$ An increase in the exchange rate represents a depreciation.
} 
distribution of these statistics is designated by $\mathrm{X}^{2}($.$) or \mathrm{F}(. .$.$) , and the degrees of freedom are in$ parentheses.

With the exception of the AR test for Japan, we can accept the null hypotheses for each of these tests, in each of these countries. In other words, all equations for all countries are well specified except for the fact that there is some evidence of residual autocorrelation for Japan.

As mentioned above, parameter constancy is a critical issue we want to analyze concerning the estimated money demand functions. Figures 4 to 10 show innovations, one step residuals, sequentially estimated one-period ahead Chow (1960) and break-point Chow (1960) statistics. In these figures, the sequentially estimated Chow statistics are labeled I upChows and NdnChows, respectively. ${ }^{28}$ Also, Tables 4 to 10 report the Hansen (1992) coefficients, variance, and joint test for parameter constancy. Finally, we test whether the model estimated over the whole sample is equivalent to that estimated over the period excluding the banking crisis. This test statistic is distributed as $\mathrm{F}(\mathrm{n} 1, \mathrm{n} 2)$, where $\mathrm{n} 1$ is the number of observations in the crisis period (i.e., the omitted observations), and $\mathrm{n} 2$ is the degrees of freedom of the model estimated over the full sample. If this F-test -labeled F-CRISIS- rejects, then we can infer that the instability in the money demand function arises from the period of the banking crisis, since the only difference between the overall sample and the sample excluding the crisis is the crisis period itself.

According to the recursively estimated Chow tests, Hansen stability tests, and F-CRISIS money demand in Chile, Denmark, Japan, and Malaysia appears to be stable. ${ }^{29}$ So, from these

\footnotetext{
${ }^{28}$ The recursively estimated Chow tests are only useful in those cases when they include the crisis periods. In some countries, however, because our data sample starts well into the crisis, the recursive estimates start after the crisis period or well into it. In these cases, we rely on the F.-CRISIS and Hansen tests for stability.

${ }^{29}$ In the case of Chile and Japan, we observe some one-period ahead Chow statistics that reject at $5 \%$, but they are too few to jeopardize the overall stability of the estimated equation.
} 
results, it seems that banking crises in these countries have not threatened the stability of the money demand equations.

The Hansen tests as well as the one-period ahead and break-point Chow tests provide evidence of parameter instability in the estimated money demand equation for Colombia. However, the instability in the equation seems to be coming from the period after the banking crisis. The Colombian banking crisis took place between 1982-87. When we estimate the model through 1989, rather than the overall sample 1981-1998, we find no evidence of instability according to the Hansen, and Chow tests (see figure 5.B.).

The one-period ahead Chow and, in particular, the break-point Chow tests provide some evidence of money demand instability in Kenya. However, the evidence is very marginal at $5 \%$ significance. Furthermore, the Hansen stability tests and the F-CRISIS indicate that the equation is stable. So, overall, we believe the results for Kenya accept the hypothesis of money demand stability.

Regarding the stability tests for the Uruguayan money equation, the results are mixed. On the one hand, the Hansen tests accept stability, but the F-CRISIS test rejects. Given that the Hansen tests typically have low power because the break-point is unknown, we are inclined to rely more heavily on the F-CRISIS test results. The one-period ahead Chow and break-point Chow tests are not particularly useful in this case because the recursive estimations conducted to obtain these tests start after the crisis period. However, it is clear from these figures, in particular from the residual bands, that the estimation in the 1980s was less precise and stable than during the 1990s. This suggests that the banking crisis during the period 1981-85 may have affected money demand stability in Uruguay. 
To summarize, the results in this section show that with the exception of Uruguay, we

find no overwhelming evidence that banking crises jeopardize broad money demand stability, ${ }^{30}$ Table 11 presents a summary of the stability test results for the money demand functions in all countries. The evidence presented here, together with the cointegration results for money, indicate that whatever changes may have occurred in the demand for money owing to the banking crises can be explained by the same function used to model money clemand at times of tranquility. Thus, we find that banking crises do not systematically threaten the short-run or longrun broad money demand functions.

\section{IV.4. Reduced single equations for prices: Do banking crises cause structural breaks in the relationship between prices and monetary indicators?}

Tables 13 through 19 report the coefficients, standard errors, and test statistics for the parsimonious price single equations estimated over the full sample for each country. By full sample, we refer to the period covering the crisis and the tranquil episodes. ${ }^{31} \mathrm{We}$ find that lagged changes in broad money (or the second difference depending on the country) have a positive and significant impact on inflation (or its growth rate depending on the country) in Chile, Denmark, Japan, Kenya, and Uruguay. Money is insignificant for Colombia and Malaysia.

For Denmark, Japan, and Uruguay, changes in income are positive and significant in explaining prices. For all other countries, income is insignificant. Changes in the exchange rate (dollar exchange rate with the exception of Denmark) are largely significant and have a positive effect on inflation. Exchange rate changes are not significant for the Colombian and Danish price equations.

\footnotetext{
${ }^{30}$ In the case of Colombia, we found evidence of instability but it seemed to be arising in the 1990s, many years after the financial crisis in this country.
} 
Foreign price changes (U.S. for all countries except Denmark where we include German prices) are, in general, positive and significant. On the other hand, foreign interest rates are significant only in the cases of Colombia and Uruguay.

Domestic interest rates (typically, the rate of return on money and its outside rate) have a negative significant impact on inflation. This is particularly the case for Chile, Japan, Malaysia, and Uruguay. For Kenya and Denmark, the own rate of return on money has a positive and significant effect.

Wage changes are significant for Colombia and Uruguay at $5 \%$ significance and for Denmark and Japan at 10\%. In general, increases in wages result in higher inflation. On the other hand, increases in unemployment have a negative impact on inflation, but they are only significant for the case of Chile and Uruguay. Finally, stock prices changes (denoted as sp) have no significant impact on consumer price inflation across country. ${ }^{32}$

The significance of the error correction terms varies largely across countries. The PPP error correction terms are significant in the case of Chile and Denmark, while the error correction term interpretable as a UIP relationship is significant in the price equations for Denmark, Japan, and Uruguay. The money error correction terms affect prices in the equations for Denmark and Japan. Finally, wage cointegrating vectors are significant only for Denmark and Japan.

At the bottom of Tables 13 to 19 , we present the diagnostic tests for residual autocorrelation (AR), skewness and excess kurtosis (normality), autoregressive conditional heteroskedasticity $(\mathrm{ARCH})$, and heteroscedasticity (hetero). None of the price equations reject any of these specification tests. Thus, none of the estimated price equations present specification problems.

\footnotetext{
${ }^{31}$ For most countries, the full sample covers approximately the period 1975-1998.

${ }^{32}$ Stock prices were only available for Chile, Colombia, and Japan.
} 
We analyze the constancy of the estimated price equations using mostly the same methodology discussed for the money demand equations (see section IV.3). Figures 13 to 19 show innovations, one step residuals, sequentially estimated one-period ahead Chow and breakpoint Chow statistics. In these figures, the Chow statistics are labeled as IupChows and NdnChows, respectively. Also, we report the Hansen coefficients, variance, and joint tests for parameter constancy. In the Hansen tests, the break point date is unknown, so a finding of instability cannot be immediately connected to a given period. Therefore, to examine whether the instability is arising directly from the banking crisis period, we conduct a Chow-type F-test (labeled F-CRISIS as before) that compares the estimation of the model for the overall sample, with the results obtained for the sample excluding the crisis period. We summarize the information on these stability tests for the price equations in Table 12.

Both the Hansen tests, and the break point Chow test indicate that the Chilean price equation is stable. Also, F-CRISIS fails to find any evidence that the banking crisis period led to instability in the price equation. We obtain similar results for the Danish and Malaysian price equations.

According to the sequentially estimated one-period ahead and break-point Chow tests, the Colombian price equation appears stable. However, the Hansen tests reject stability. In particular, these statistics point to variance instability. This seemingly contradictory results can be reconciled by the fact that the recursive estimations start well into the sample. In other words, the Chow tests are not very useful in this case, because they practically do not cover the crisis period. ${ }^{33}$ The F-CRISIS test rejects the hypothesis that both periods can be explained by the same

\footnotetext{
${ }^{33}$ The Colombian crisis took place between 1982-88. Recursive estimations for the price equation start around 1987.
} 
equation. This seems to point to the fact that the price equation is particularly unstable during the banking crisis in Colombia.

Regarding the stability of the Japanese price equation, the Hansen tests indicate the presence of instability. However, this applies only to variance instability and the evidence is marginal, since the critical value for the Hansen variance test at $5 \%$ significance is roughly 0.5 and the test statistic is 0.52 (Hansen (1992)). Furthermore, the break-point Chow and F-CRISIS tests, indicate parameter constancy over the crisis period.

In the case of Kenya, the Hansen tests for variance stability, the one-period ahead, and the break point Chow tests indicate that the equation is not constant. In particular, we can observe from the recursively estimated Chow tests that the instability seems to occur during the 1990s. Kenya experienced two banking crises one over the period 1985-89 and another over the period 1992-95. The F-test for the 1980s crisis suggests that this period is not different from the overall sample. However, the 1990s crisis does appear to be different than the non-crisis period.

The evidence on stability for the Uruguayan price equation is mixed. The Hansen test accepts stability, but F-CRISIS, rejects. Thus, we are inclined to rely on the F-CRISIS result. The one-period ahead Chow and break-point Chow tests are not useful in this case because the recursive estimations conducted to obtain these tests start after the crisis period. However, we can see from the residual bands that the estimation in the 1980s was less precise and stable than during the $1990 \mathrm{~s}$.

The parameter constancy results discussed above focus mostly on the overall stability of the price equations. In order to test whether individual coefficients in the price equation are affected by the banking crises, we include interaction terms of each variable with a dummy that takes a value of one during the crisis periods. These results are reported in tables 20 through 26 . 
With respect to the interaction terms for money, they are negative in the case of Chile, Colombia, and Japan. This indicates that the coefficient on money is smaller during the banking crises in these countries. However, Japan is the only country where these interaction terms are significant. The interaction terms for money are positive for Denmark, Kenya, Malaysia, and Uruguay, but they are only significant at the $5 \%$ level in the case of the latter.

Regarding other indicators such as exchange rates, domestic interest rates, and stock prices, we find only marginal changes in the coefficients for exchange rates during crisis periods for Malaysia. Neither interest rates nor stock prices exhibit a significant increase or decrease in their coefficients during the banking crisis periods. Furthermore, we find that with the exception of Kenya, all interaction terms are jointly insignificant.

To summarize, the results from this section indicate that money, exchange rates, foreign prices, and domestic interest rates are significant in explaining prices in most countries. Stock prices, on the other hand, are not useful indicators of price behavior. In general, the relationship between prices and individual monetary indicators is stable, despite the occurrence of crises. However, in three out of seven countries we find some evidence of variance instability in the price equations.

\section{V - Conclusions}

Until very recently, not much attention was devoted to the monetary impact of banking crises. Two exceptions, Garcia-Herrero (1997) and Lindgren et al. (1996), warned about some of the adverse effects of banking crises for the conduct of monetary policy. Using mostly a descriptive approach, the authors argue that banking crises have significant implications for money demand stability, for the effectiveness of instruments, for the relationship between prices 
and monetary indicators, and for the overall impact of monetary policy. Though both of these studies are very interesting and informative, they arrive at their conclusions without a systematic empirical investigation of the issues they raise.

This study has attempted to fill this void in the literature on the monetary impact of banking crises. Using cointegration analysis and error correction modeling, we examined the claim that banking crises jeopardize money demand stability. Secondly, we used the same empirical methodology to examine the overall stability of the process for inflation, as well as the impact of crises on the coefficients of individual monetary indicators.

Our results suggest that the stability of money demand is not threatened by banking crises. With the exception of Uruguay, we found that money demand functions are stable. Regarding the indicators of price behavior, we found that changes in money, exchange rates, foreign prices, and domestic interest rates seem to be useful in explaining prices. Finally, even though in general we did not find that individual coefficients in the price equations change as a result of banking crises, in three out of the seven countries, we uncovered evidence of variance instability in these equations due to crises.

Given the results in this paper, we can draw two main conclusions that might be helpful for policy-makers facing banking crises. First, policymakers in countries undergoing crises should not be worried about the structural stability of money demand functions. Our results indicate that the behavior of money demand during crises can be modeled by the same function as during periods of tranquility. Second, although individual coefficients in the price equations do not seem to be severely affected by crises, policy-makers should be aware that crises, in some instances, can give rise to variance instability in the price/inflation equations. 


\section{References}

Abdullah, Ahmad Zainudin and Zulkornain Yusop (1996), "Money Inflation and Causality: The Case of Malaysia (1970-992)," Asian Economic Review, vol. 38, no. 1, 44-51.

Adam, Christopher (1992), "Recent Developments in Econometric Methods: an Application to the Demand for Money in Kenya," African Economic Research Consortium, Special Paper, No. 15.

(1992), "On the Dynamic Specification of Money Demand in Kenya,"

Journal of African Economies, vol. 1, no. 2, 233-270.

Apt, Jaime and Jorge A. Quiroz (1992), "Una Demanda por Dinero Mensual para Chile: 1983:1 1992:8," Revista de Analisis Economico, vol. 7, no. 2, 103-139.

Arize, Augustine C. (1990), "Effects of Financial Innovations on the Money Demand Function: Evidence from Japan," International Economic Journal, vol. 4, no. 1, 59-70. , S. L. Avard, V. Ukpolo (1997), "Multivariate Cointegration Tests of the Impact of International Factors on Money Demand," The International Journal of Finance, vol 9, no. 1, 482-504.

Baba, Yoshihisa, David F. Hendry, Ross M. Starr (1992), "The Demand for M1 in the USA, 1960-1988," Review of Economic Studies, vol. 59, no. 198, 25-61.

Baumgartner, J. and R. Ramaswamy (1996), "Inflation Targeting in the United Kingdom: Information Content of Financial and Monetary Variables," IMF Working Paper, WP/96/44.

and R. Ramaswamy, and Goran Zettergren (1997), "Monetary Policy and

Leading Indicators of Inflation in Sweden," IMF Working Paper, WP/97/34.

Bayoumi, Tamim (1998), “Japan: Selected Issues," IMF Staff Country Report No. 98/113. 
Brownbridge, Martin (1998), "Financial Distress in Local Banks in Kenya, Nigeria, Uganda, and Zambia: Causes and Implications for Regulatory Policy," Development Policy Review, 173-88.

Brunello, Giorgio (1995), "Recent Changes in the Internal Structure of Wages and Unemployment in Japan," Journal of the Japanese and International Economies, vol. 9, 105-129.

Caprio, Gerard and Daniela Klingebiel (1996), "Bank Insolvency: Bad Luck, Bad Policy, or Bad Banking?" World Bank -Annual Bank Conference on Development Economics.

Caramazza, Francesco and Slawner, Chad (1991), "The Relationship Between Money, Output and Prices," Bank of Canada, Working Paper 91-4.

Chakrabarti, Santi K. and J. A. Ali (1992), "Prices in Kenya: An Empirical Investigation," Harvard Institute for International Development, Development Discussion Paper, 1-22. Chow, Gregory (1960), "Tests of Equality between Sets of Coefficients in Two Linear Regressions," Econometrica, 28, 3, 591-605.

Chye, Tan Eu, and M. Semudram (1988), "The monetary Versus Neo-Keynesian Controversy over Inflation: The Malaysian Evidence," The Indian Economic Journal, vol. 36, No. 1, July-September, 48-54.

Corker, Robert (1990), "Wealth, Financial Liberalization, and the Demand for Money in Japan," IMF Staff Papers, vol. 37, no. 2, June 1990, 418-432.

Cuthbertson, K, and M. P. Taylor (1988), "Alternative Scale Variables in the U.S. Demand Function for Narrow Money: Some Non-nested Tests," The Cyprus Journal of Economics, vol. 1, no. 2, 102-110.

Darby, M., Angel Mascaro and Michael Marlow (1989), "The Empirical Reliability of Monetary 
Aggregates as Indicators: 1983-1987," Economic Inquiry, vol. XXVII.

Darrat, Ali F. (1985), "The Demand for Money in a Developing Economy: The Case of Kenya," World Development, 13, October/November, 1163-70.

Davis, E.P. and S.G.B. Henry (1994), "The Use of Financial Spreads as Indicator Variables: Evidence for the UK and Germany," IMF Working Paper, WP/94/31.

Dhakal, Dharmendra, Magda Kandil, Subhash C. Sharma, and Paul B. Trescott (1993), "The Inflationary Experiences of Six Developing Countries in Asia: an Investigation of Underlying Determinants," Applied Economics, vol. 25, no. 3, 413-425.

De Brouwer, Gordon and Neil Ericsson (1998), "Modelling Inflation in Australia," Journal of Business and Economics Statistics, Vol , No.4, 433-449.

Demirguc-Kunt, Asli and Enrica Detragiache (1997), "The Determinants of Banking Crises:

Evidence from Industrial and Developing Countries," The World Bank Policy Research Working Paper 1828, September.

Dickey, D. and W.A. Fuller (1981), "Likelihood Ratio Statistics for Autoregressive Time Series with a Unit Root," Econometrica, 49, 1057-1072.

Dominioni, Daniel and Jose-Antonio Licandro (1989), "La Banca Privada Uruguaya en la Crisis de los Anos Ochenta," Monetaria, Centro de Estudios Monetarios Latinoamericanos, vol. 12 , no. $2,197-223$.

Doornik, Jurgen and David F. Hendry (1997), Modeling Dynamic Systems Using PcFiml 9.0, International Thomsom Business Press, London.

Ericsson, Neil R. (1992), "Cointegration, Exogeneity, and Policy Analysis: An Overview," Journal of Policy Modeling 14(3), 251-280. , David F. Hendry, and Kevin M. Prestwich (1998), "The Demand for 
Broad Money in the United Kingdom, 1878-1993," Scandinavian Journal of Economics, $100(1), 289-324$ and Sunil Sharma (1998), "Broad Money Demand and Financial Liberalization in Greece," Empirical Economics, 23, 417-436.

Fielding, David (1994) "Money Demand in Four African Countries," Journal of Economic Studies, vol. 21, no. 2, 3-37.

Friedman, B. and Kenneth N. Kuttner (1992), "Money, Income, Prices and Interest Rates," American Economic Review, Vol. 82, No.3, 472-492.

Friedman, M. And Anna Jacobson Schwartz, A Monetary History of the United States, Princeton University Press, Princeton, 1963.

Frowen, Stephen F. and Herbert Buscher (1990), “The Demand for Money in the U.S., UK, Japan and West Germany: an Empirical Study of the Evidence since 1973," University College London Dept. of Economics. Discussion Papers in Economics, No. 90-05.

Fullerton, Thomas M. Jr. (1993), "Inflationary Trends in Colombia," Journal of Policy Modeling, vol. 15, no. 4, 463-468.

Garcia-Herrero, Alicia (1997), "Monetary Impact of a Banking Crisis and the Conduct of Monetary Policy," IMF Working Paper,WP/97/124. , "Banking Crises in Latin America in the 1990s: Lessons from Argentina, Paraguay and Venezuela," IMF Working Paper, WP/97/140. Geraghty, Coleen (1987), "Countrywatch: Malaysia, Banks Worry About Bad Debts and Funding Costs," Asian Finance, 40-51.

Goldsbrough, D. and I. Zaidi (1989), "Monetary Policy in the Philippines during Periods of Financial Crisis and Changes in Exchange Rate Regime: Targets, Instruments, and the 
Stability of Money Demand," IMF Working Paper, WP/89/98.

Gosh, B. and S.C. Gan (1994), "On the Choice of Appropriate Money Stock for Malaysia," The Indian Journal of Economics, nr. 297, 269-279.

Graziani, Carlo (1988), "La Dinamica de la Inflacion: el Caso de Uruguay," Monetaria, Centro de Estudios Monetarios Latinoamericanos, Vol. 11, no. 1, 41-66.

Greene, William (1993), Econometric Analysis, Second Edition, Macmillan Publishing Company, New York.

Habibulla, Muzafar Shab (1990), "Choice of Scale Variable and the Specification of the Malaysian Money Demand function: A Note," The Indian Economic Journal, vol. 38, no. $1,79-88$.

(1991), "Money and Its Substitutes in a Developing Economy:

Empirical Evidence from Malaysia," The Indian Economic Journal, vol. 39, no. 1, 6072.

Hamann, Javier (1993), "Financial Liberalization and the Information Content of Money in Indonesia, Korea and the Philippines," IMF Working Paper, WP/93/88.

Hausmann, Ricardo and Liliana Rojas-Suarez, Banking Crises in Latin America, Inter-American Development Bank, Washington D.C.

Hamilton, James (1994), Time Series Analysis, Princeton University Press, Princeton, New Jersey.

Hansen, Bruce (1992), "Testing for Parameter Instability in Linear Models," Journal of Policy Modeling, 14(4), 517-533.

Hendry, David F. and Jurgen A. Doornik (1999), Empirical Econometric Modeling Using PcGive 9.0, Timberlake Consultants Ltd., UK. 
Herrera, Santiago and A., Juan Manuel Julio (1993), "La Demanda de Dinero en la Corto y en la Largo Plazo en Colombia," Conyuntura Economica, vol. 23, no. 1, 91-107.

Herrera, Luis Oscar and Rodrigo Vergara (1992), "Estabilidad de la Demanda de Dinero, Cointegration y Politica Monetaria," Cuadernos de Economia, vol. 29, no. 86, 35-54.

Horrigan, Brian (1986), “Monetary Indicators, Commodity Prices, and Inflation," Federal Reserve Bank of Philadelphia, Working Paper No., 86-7.

Hostland, D., Poloz S., and P. Storer (1987), "An Analysis of the Information Content of Alternative Monetary Aggregates," Bank of Canada Technical Reports. No. 48. Hutchison, Michael (1998) "Empirical Determinants of Banking Crises: Japan's Experience in International Perspective," University of California, Santa Cruz, Working Papers 422, 136.

Johansen, S. (1988), "Statistical Analysis of Cointegration Vectors," Journal of Economic Dynamics and Control, 12, 231-254. and Katarina Juselius (1990), "Maximum Likelihood Estimation and Inference on Cointegration - with Applications to the Demand for Money," Oxford Bulletin of Economics and Statistics, 52, 2, 169-211. (1991), "Estimation and Hypothesis Testing of Cointegration Vectors in

Gaussian Vector Autoregressive Models," Econometrica, 59, 6, 1551-1580. (1994), "The Role of the Constant and Linear Terms in Cointegration Analysis of Nonstationary Variables," Econometric Reviews, 13(2), 205-229. (1995), Likelihood-based Inference in Cointegrated vector Autoregressive Models, Oxford, Oxford University Press. Juselius, Katarina (1988), "Cointegration and Identification in a Vector Time Series Model an 
Application to the Demand for Money in Denmark," Discussion Papers from Institute of Economics, University of Copenhagen, 88-03. (1989), "Long-run Relations in a Well-defined Statistical Model for the Data

Generating Process. Cointegration Analysis of the PPP and the UIP Relations for Denmark and Germany," Discussion Papers from Institute of Economics, University of Copenhagen, $90-11$. (1992), "Domestic and Foreign Effects on Prices in an Open Economy: The

Case of Denmark," Journal of Policy Modeling, vol. 14, no. 4, 1992, 401-428. (1993), "VAR Modeling and Haavelmo's Probability Approach to Macroeconomic Modeling," Empirical Economics, 18, 1993, 595-622. (1998), "Changing Monetary Transmission mechanisms within the EU," Empirical Economics, 23, 455-481.

Kamas, Linda (1995), "Monetary Policy and Inflation under the Crawling Peg: Some Evidence from VARs for Colombia," Journal of Development Economics, vol. 46, 145-161. Karatzas G. (1993), "Government Deficits, Monetization, International Reserve Flows, and Inflation in Selected African Countries," Economia Internazionale, 46, May-Aug, 201 -224 .

Koskenyla, Heikki (1994), "The Nordic Banking Crises," Bulletin, Bank of Finland, 15-22.

Lindgren, C., Gillian Garcia and Matthew I. Saal (1996), Bank Soundness and Macroeconomic Policy, IMF publication services, Washington, D.C.

Machua, Wilfred (1986), "Kenya's Bank Failures: Bankers Speak Out," African Business, $22-24$

Magendzo W., Igal, "La Politica Monetaria en Chile en la Decada de los Noventa: Objectivos, 
Herramientas e Indicadores," Serie de Estudios Economicos, No. 41.

Martner, Ricardo F. and Daniel Titelman K. (1993), "Un Analisis de Cointegracion de las Funciones de Demanda de Dinero: el Caso de Chile," EL Trimestre Economico, Mexico, vol. LX(2), 413-446.

Mathieson, D. and Haas, R. (1994), "Establishing Monetary Control in Financial Systems with Insolvent Institutions," IMF Paper on Policy Analysis and Assessment, PPAA/94/10.

Matte, Ricardo E. and Patricio Rojas R. (1989), "Evolucion Reciente del Mercado Monetario y una Estimacion de la Demanda por Dinero en Chile," Cuadernos de Economia, vol. 26, no. 78, 195-216.

Mbitiru, Chege (1986), "Bank Collapse Forces Government Action," Africa Now, 31-32. McNown, Robert and Myles S. Wallace (1989), "National Price Levels, Purchasing Power Parity, and Cointegration: A Test of Four High Inflation Economies," Journal of International Money and Finance, vol. 8, no. 4, 533-545.

Miller, Stephen M. (1991), "Monetary Dynamics: An Application of Cointegration and Error Correction Modeling," Journal of Money, Credit and Banking, vol. 23, no. 1, 139-154. Muhleisen, Martin (1995), "Monetary Policy and Inflation Indicators for Finland," IMF Working Paper, WP/95/115.

Mwega, F. M. and Tony Killick (1990), “Monetary Policy in Kenya, 1967-88," Eastern Africa Economic Review, vol. 6, no. 2, 117-142.

Njuguna Ndung'u (1993), "Dynamics of the Inflationary Process in Kenya," Ekonomiska studier utgivna av Nationalekonomiska institutionen handelshögskolan vid Göteborgs universitet , 47.

Perez-Campanero, Juan and Alfredo M. Leone (1991), "Liberalization and Financial Crisis in 
Uruguay (1974-1987)," IMF Working Paper,WP/91/30.

Reinhart, Carmen and Vincent R. Reinhart (1991), “Output Fluctuations and Monetary Shocks:

Evidence from Colombia," IMF Working Paper, WP/91/35.

Sheng, Andrew (1996), Bank Restructuring, Lessons from the 1980s, The World Bank, 1996

Sims, Christopher A (1972), "Money, Income, and Causality," American Economic Review, $62,540-52$.

, "Comparison of Interwar and Postwar Business Cycles: Monetarism

Reconsidered," American Economic Review, (Papers and Proceedings), 70, 250-7.

Soejima, Yutaka (1996), "The Long-Run Relationship between Real GDP, Money Supply, and

Price Level: Reexamination of Cointegration Test," IMES Discussion Paper 96-E-9.

Stock, James and Watson, Mark W. (1989), "Interpreting the Evidence on Money-Income Causality,"Journal of Econometrics, 40, 161-82.

Sundararajan, V. and T. Baliño, Banking Crises: Cases and Issues, IMF Publication Services, Washington, D.C., 1991.

Tamura, Tatsuya (1992), "Monetary Control in Japan," in Monetary Policy an Financial Innovations in Five Industrial Countries, Edited by Stephen F. Frowen, St. Martin's Press, New York, 101-119.

Wonsewer, Israel (1986), "La Inflacion en la Uruguay," Pensamiento Iberoamericano, Enero/ Junio, 167-172.

Wunder, Dieter (1990), "Inflacion en Colombia: Estimacion de un Modelo de Ecuaciones Simultaneas," Estudios de Economia, vol 17. No. 1, Jun. 90, 283-342.

Yoshida, Tomoo (1990), "On the Stability of Japanese Money Demand Function: Estimation Results Using the Error Correction Model," Bank of Japan Monetary and Economic 
Studies, vol. 8 , no. 1, 1-48.

Yoshikawa, Hiroshi and Yoshiyuki Takeuchi (1989), "Real Wages and the Japanese Economy," Bank of Japan Monetary and Economic Studies, vol. 7, no. 1, 1-39.

Yusoff, Mohammed bin (1988), "Money, Prices, and Balance of Payments in Malaysia," The

Indian Economic Journal, vol. 36, No. 1, July-September, 33-47. 
TABLE 1 - Cointegration Results: Money Demand

\begin{tabular}{|c|c|c|}
\hline $\begin{array}{l}\text { Country' } \\
\text { Vector Name }\end{array}$ & $\operatorname{Rank}$ & $\begin{array}{l}\text { Cointegrating Relations } \\
\text { (standard error in parentheses) }\end{array}$ \\
\hline $\begin{array}{l}\text { Chile }^{1} \\
\text { ChiECMrM2 }\end{array}$ & 3 & $\begin{array}{c}(\mathrm{m}-\mathrm{p})=-0.0308 * \Delta \mathrm{p}+\mathrm{y}+0.0035 * \mathrm{t} \\
(0.0028) \\
(0.0005)\end{array}$ \\
\hline ChiECMytrend & & $\begin{array}{c}y=0.0039 * t \\
(0.0003)\end{array}$ \\
\hline ChiECMlown & & $1^{\mathrm{O}}$ \\
\hline Colombia & 2 & \\
\hline ColECMnM2 & & $\begin{array}{r}m=p+y+0.0018 * t \\
(0.0002)\end{array}$ \\
\hline ColECMlown & & $\begin{aligned} I^{\circ}= & -0.0308 * t \\
& (0.0089)\end{aligned}$ \\
\hline Denmark $^{2}$ & 2 & \\
\hline DenECMrM2 & & $\begin{array}{c}(m-p)=-0.0207 * \Delta p+y+0.064 * I^{\circ}-0.064 * I^{A}-0.19 * \text { CapConDum } \\
(0.0029) \\
(0.007)(0.041)\end{array}$ \\
\hline DenECMinfl & & 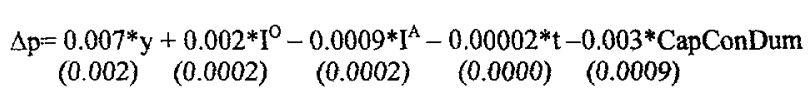 \\
\hline $\begin{array}{l}\text { Japan }^{3} \\
\text { JapECMrM2 }\end{array}$ & 1 & $(m-p)=-0.0909 * \Delta p+y+0.239 * I^{\circ}-0.23 * I^{A}$ \\
\hline Kenya ${ }^{4}$ & 3 & \\
\hline KenECMnM2 & & $\begin{array}{c}m=p+y+-0.235^{*} Y^{A}+0.0174^{*} t \\
(0.006) \quad(0.003)\end{array}$ \\
\hline KenECMgdp & & $\begin{array}{c}y=0.065 * \mathrm{I}^{\mathrm{O}}+0.0006 * \mathrm{t} \\
(0.005) \quad(0.0005)\end{array}$ \\
\hline KenECMispr & & $\begin{array}{c}I^{0}=I^{A}-0.0403 * t \\
(0.009)\end{array}$ \\
\hline Malaysia $^{5}$ & 4 & \\
\hline MysECMrM2 & & $(m-p)=-0.25 * \Delta p+y$ \\
\hline MysECMytrend & & $\begin{aligned} y= & 0.008 * t \\
& (0.0001)\end{aligned}$ \\
\hline MysECMIown & & $\begin{array}{r}I^{O}=- \\
-0.0368 * t \\
(0.0085)\end{array}$ \\
\hline MysECMIalt & & $\begin{aligned} I^{A}=- & -0.038 * t \\
& (0.0083)\end{aligned}$ \\
\hline $\begin{array}{l}\text { Uruguay }^{6} \\
\text { UruECMrM2 }\end{array}$ & 1 & $\begin{array}{ccc}(m-p)= & -0.0172 * \Delta p+y+0.018^{*} I^{0}+0.0027^{*} t \\
(0.0028) & (0.003) & (0.0006)\end{array}$ \\
\hline
\end{tabular}

This table reports the restricted cointegrating relations found for the monetary sector. Johansen's (1988) methodology was used to determine the number of cointegrating vectors and to test parameter restrictions on these vectors. Definition of variables: $m$ represents the $\log$ of M2, $p$ is the $\log$ of CPI, $y$ is the log of a measure of income (usually industrial production), $I^{o}$ is the own rate of money, $I^{A}$ is the alternative (outside) rate, and $t$ is a time trend.

\footnotetext{
${ }^{1}$ Dummies for Dec.79, Jun.82, July82, Sept.84 and Oct.84 were included as unrestricted variables in the cointegration. See Table A.5.

${ }^{2}$ The following dummies were included as unrestricted variables: DVAT, DPRSTOP, DCOTAX, D92Q4, D83Q1, D83Q2, Dec.92,

Jun.93, Jul.93, Aug.93. See Table A.5.

${ }^{3}$ The following dummies were included as unrestricted variables: May90, Apr.90, Apr.89, and Apr.97. See Table A.5.

${ }^{4}$ The following dummies were included as unrestricted variables: Feb.80, Jul.81, Mar.88, Mar.93. See Table A.5.

${ }^{5}$ The following dummies were included as unrestricted variables: Jan.84, Feb.84, Mar.84. See Table A.5.

${ }^{6}$ The following dummies were included as unrestricted variables: Nov.82, Dec.82, Dec.87, Jan.88, Nov.89, Dec.89, Jan.90, and Dec.92. See Table A.5.
} 
TABLE 2 - Cointegration Results: Wages

\begin{tabular}{|c|c|c|}
\hline Country/Vector Name & Rank & Cointegrating Relations (standard error in parentheses) \\
\hline $\begin{array}{l}\text { Chile } \\
\text { ChiECMrwage }\end{array}$ & 1 & $\begin{array}{c}(\mathrm{w}-\mathrm{p})=-0.0104^{*} \Delta \mathrm{p}-0.2279 * \mathrm{u}-0.0016^{*} \mathrm{t} \\
(0.0018) \quad(0.0428)(0.0004)\end{array}$ \\
\hline $\begin{array}{l}\text { Colombia }^{8} \\
\text { ColECMnwage }\end{array}$ & 1 & $\begin{array}{c}\mathrm{w}=\mathrm{p}+0.0012 * \mathrm{t} \\
(0.0001)\end{array}$ \\
\hline $\begin{array}{l}\text { Denmark }^{9} \\
\text { DenECMrwage }\end{array}$ & 1 & $\begin{array}{c}(w-p)=-0.0424 * \Delta p-1.26 * u+0.0027 * t \\
(0.0242) \quad(0.293)(0.001)\end{array}$ \\
\hline $\begin{array}{l}\text { Japan }^{10} \\
\text { JapECMrwage }\end{array}$ & 1 & 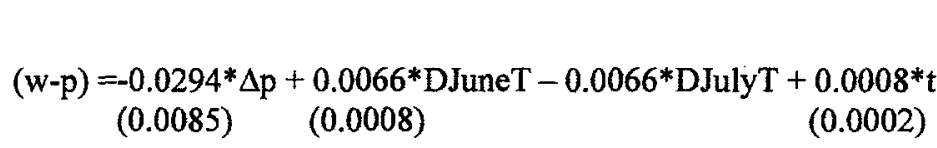 \\
\hline $\begin{array}{l}\text { Uruguay }^{11} \\
\text { UruECMrwage }\end{array}$ & 1 & $(w-p)=-0.0025^{*} \Delta p-0.3483^{*} u$ \\
\hline
\end{tabular}

This table reports the restricted cointegrating relations found for the labor sector. Johansen's (1988) methodology was used to determine the number of cointegrating vectors and to test parameter restrictions on these vectors. Definition of Variables: $w$ is the log of wages, $p$ represents the log of CPI, $u$ is the log of the unemployment rate, and $t$ is a time trend.

\footnotetext{
${ }^{7}$ The following dummies were included in the cointegration analysis as unrestricted variables: Jun.82, Jul.82, Sep.84, and Oct.84. See Table A.5.

${ }^{8}$ The seasonal dummies included in this cointegration are centered seasonals. In addition, each centered seasonal is interacted with a dummy variable for 1990 . See Table A.5.

${ }^{9}$ The following dummies were included as unrestricted variables: DumVAT, DumPRSTOP, and DumCOTAX. See Table A.5.

${ }^{10}$ The following two dummies enter as unrestricted variables: Apr.89 and Apr.97. See Table A.5.

${ }^{11}$ The following dummies were included as unrestricted variables: Nov.82, Dec.82,Dec.87, Jan.88, Nov.89, Dec.89, Jan.90, and Dec.92. See Table A.5.
} 
TABLE 3 - Cointegration Results: External Sector

\begin{tabular}{|c|c|c|}
\hline $\begin{array}{l}\text { Country' } \\
\text { Vector Name }\end{array}$ & Rank & $\begin{array}{l}\text { Cointegrating Relations } \\
\text { (standard error in parentheses) }\end{array}$ \\
\hline $\begin{array}{l}\text { Chile }^{12} \\
\text { ChiECMrPPP }\end{array}$ & 1 & $\begin{aligned}(\mathrm{p}-\mathrm{e})= & -0.0506^{*} \Delta \mathrm{p}+\mathrm{p}^{*} \\
& (0.0083)\end{aligned}$ \\
\hline $\begin{array}{l}\text { Colombia } \\
\text { ColECMnPPP }\end{array}$ & 3 & $n=e+n^{*}$ \\
\hline ColECMIdom & & I \\
\hline ColECMIfor & & $1^{*}$ \\
\hline Denmark $^{13}$ & 2 & \\
\hline DenECMrPPP & & $\begin{aligned}(p-e)= & -0.0097^{*} \Delta p+p^{*} \\
& (0.0022)\end{aligned}$ \\
\hline DenECMuip & & $\begin{array}{r}I=I^{*}+\Delta p-0.015^{*} t \\
(0.006)\end{array}$ \\
\hline Japan $^{14}$ & 2 & \\
\hline JapECMrPPP & & 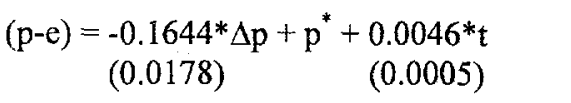 \\
\hline JapECMuip & & $\begin{array}{c}\mathrm{I}=\mathrm{I}^{*}+\Delta \mathrm{p}+0.0237 * \mathrm{t} \\
(0.005)\end{array}$ \\
\hline $\begin{array}{l}\text { Kenya } \\
\text { KenECMnPPP }\end{array}$ & 2 & $p=e+p^{*}+4.016^{*} I-4.016^{*} I^{*}-0.337 * t$ \\
\hline KenECMidiff & & $\begin{array}{r}I=1.05 * I^{*}+0.084 * t \\
(0.016)\end{array}$ \\
\hline Malaysia $^{15}$ & 1 & \\
\hline MysECMrPPP & & $\begin{aligned}(p-e)= & 0.2696^{*} \Delta p+p^{*} \\
& (0.0529)\end{aligned}$ \\
\hline Uruguay & 2 & \\
\hline UruECMrPPP & & $\begin{array}{c}(p-e)=0.0074^{*} \Delta p+p^{*}+0.0058^{*} t \\
(0.0026)\end{array}$ \\
\hline UruECMuip & & $\mathrm{I}=\Delta \mathrm{p}+\mathrm{I}^{*}-0.0487^{*} \mathrm{t}$ \\
\hline
\end{tabular}

This table reports the restricted cointegrating relations found for the external sector. Johansen's (1988) methodology was used to determine the number of cointegrating vectors and to test parameter restrictions on these vectors. Definition of Variables: $p$ represents the log of CPI, $e$ is the log of the exchange rate (usually expressed as units of national currency per US\$), $I$ is the domestic interest rate, $I^{*}$ represents the foreign interest rate, $p^{*}$ represents the $\log$ of the foreign price level (CPI), and $t$ is a time trend.

\footnotetext{
${ }^{12}$ The following dummies were included in the cointegration analysis as unrestricted variables: Jun.82, Jul.82, Sep.84, and Oct.84. See Table A.5.

${ }^{13}$ A dummy for capital controls (dumcapcon) was allowed to enter as a restricted variable in the cointegration space. The following dummies were included unrestricted: DVAT, DPRSTOP, DCOTAX, D924, 83Q1, 83Q2, Dec.92, Jun.93, Jul.93, and Aug.93. See Table A.5.

${ }_{14}^{14}$ The following two dummies were included as unrestricted variables: Apr.89 and Apr.97. See Table A.5.

${ }^{15}$ The following dummies were included as unrestricted variables: Jan.84, Feb.84, Mar.84. See Table A.5.
} 
TABLE 4 - CHILE: Single Equation for Money (Modeling $\Delta(m-p)$ )

\begin{tabular}{|l|c|c|c|c|}
\hline \multicolumn{1}{|c|}{ Variable } & Coefficient & Std. Error & t-value & Hansen Instability \\
\hline Constant & -0.069 & 0.103 & -0.676 & 0.12 \\
\hline$\Delta(m-p)_{t-1}$ & -0.130 & 0.069 & -1.897 & 0.41 \\
\hline$\Delta^{2} p_{t}$ & -1.002 & 0.244 & -4.103 & 0.08 \\
\hline$\Delta y_{t}$ & 0.085 & 0.041 & 2.089 & 0.04 \\
\hline$\Delta I_{t}^{O}$ & 0.001 & 0.000 & 3.687 & 0.11 \\
\hline$\Delta e_{t}$ & 0.031 & 0.098 & 0.319 & 0.05 \\
\hline chiECMrM2 & -0.050 & 0.009 & -5.789 & 0.13 \\
\hline chiECMytrend $t_{t-1}$ & 0.085 & 0.024 & 3.593 & 0.12 \\
\hline chiECMIown $_{t-1}$ & 0.007 & 0.000 & 3.697 & 0.15 \\
\hline
\end{tabular}

Sample: 1978:10-1993:11

$R^{2}=0.593958 \quad F(24,157)=9.5691[0.0000] \quad \sigma=0.0231$

$\begin{array}{llc}\text { AR 1- 7 F ( 7,150) } & = & 0.36271[0.9226] \\ \text { ARCH 7 F (7,143) } & = & 0.3335[0.9376] \\ \text { Normality Chi }{ }^{2}(2) & = & 1.0704[0.5855] \\ \text { HETERO F }(32,124) & = & 0.57818[0.9629]\end{array}$

Hansen Instability Test Results: Variance: 0.163305 Joint (variance \& coefficients): 3.99966 F-CRISIS $(80,77)=1.3427[0.0975]$

FIGURE 4 - CHILE: Recursive estimation for money demand

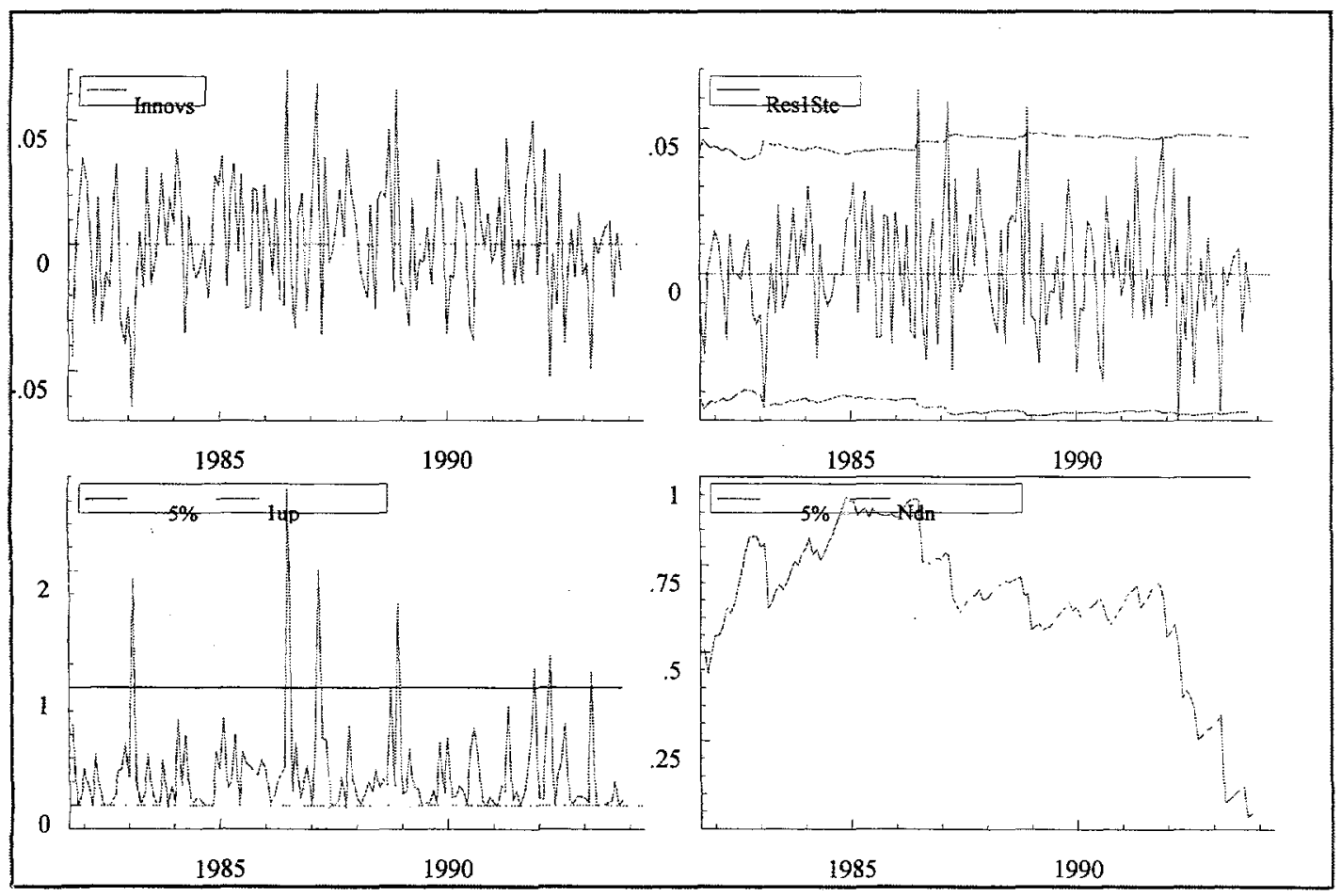

For a list of and explanation for the dummies used in estimation, see Table A.5. 
TABLE 5 - COLOMBIA: Single Equation for Money (Modeling $\Delta m$ )*

\begin{tabular}{|l|c|c|c|c|}
\hline \multicolumn{1}{|c|}{ Variable } & Coefficient & Std. Error & t-value & Hansen Instabilitity \\
\hline Constant & 0.334 & 0.070 & 4.743 & 0.16 \\
\hline$\Delta m_{t-1}$ & 0.139 & 0.071 & 1.952 & $0.70^{*}$ \\
\hline$\Delta p_{t-6}$ & -0.274 & 0.152 & -1.806 & 0.09 \\
\hline$\Delta y_{t}$ & 0.032 & 0.023 & 1.356 & 0.35 \\
\hline$\Delta V_{t-10}^{o}$ & 0.001 & 0.001 & 1.366 & 0.26 \\
\hline$\Delta e_{t-3}$ & 0.121 & 0.065 & 1.868 & $0.54^{*}$ \\
\hline$\Delta e_{t-4}$ & -0.184 & 0.066 & -2.765 & $0.54^{*}$ \\
\hline$\Delta e_{t-12}$ & -0.136 & 0.066 & -2.066 & 0.25 \\
\hline colECMnM2 $_{\mathrm{t}-1}$ & -0.043 & 0.011 & -3.891 & 0.17 \\
\hline colECMIown & -0.000 & 0.000 & -0.529 & 0.15 \\
\hline
\end{tabular}

Sample: $1982: 3-1998: 6$

$\mathrm{R}^{2}=0.584623 \quad \mathrm{~F}(20,175)=12.315[0.0000] \quad \sigma=0.01223$

$\begin{array}{lll}\text { AR 1- 7 F ( 7,168) } & = & 0.98872[0.4412] \\ \text { ARCH 7 F }(7,161) & = & 0.88705[0.5182] \\ \text { Normality Chi }{ }^{2}(2) & = & 5.9558[0.0509] \\ \text { HETERO F }(29,145) & = & 1.4148[0.0948]\end{array}$

Hansen Instability Test Results: Variance: $0.713604^{*}$ Joint (variance $\&$ coefficients): 4.75832

F-CRISIS $(70,105)=0.57249[0.9933]$

FIGURE 5a - COLOMBIA: Recursive estimation for money demand

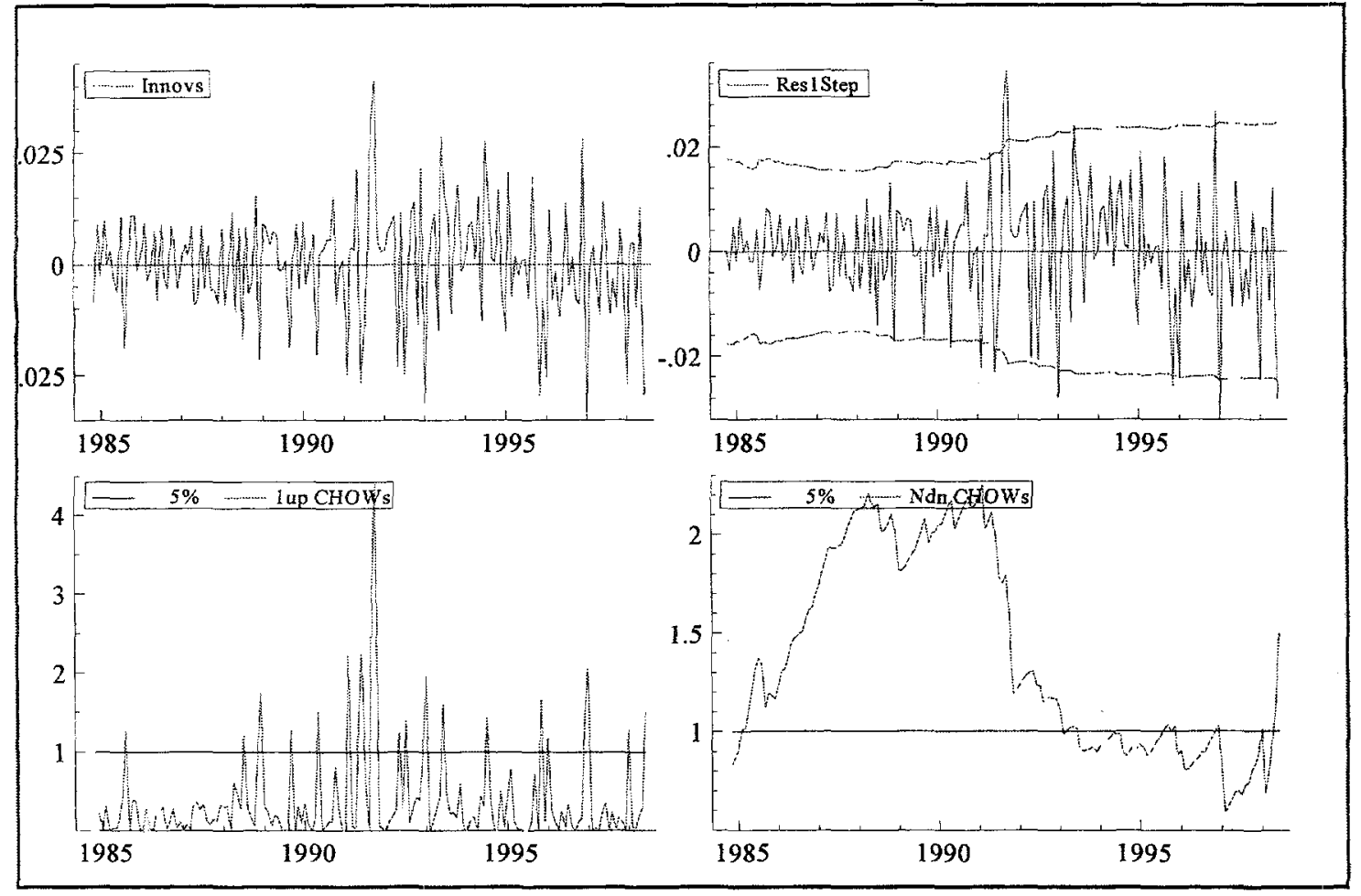

"For a list of and explanation for the dummies used in the estimation, see Table A.5.

* Denotes significance at $5 \%$. 
COLOMBIA: Single Equation for Money (Modeling $\Delta m$ ), continued

For Sub-sample: $1982(3)$ to 1989 (12)

Hansen Instability Test Results: Variance: 0.0860424 Joint (variance \& coefficients): 4.29042

FIGURE 5b - COLOMBIA: Recursive estimation for money demand

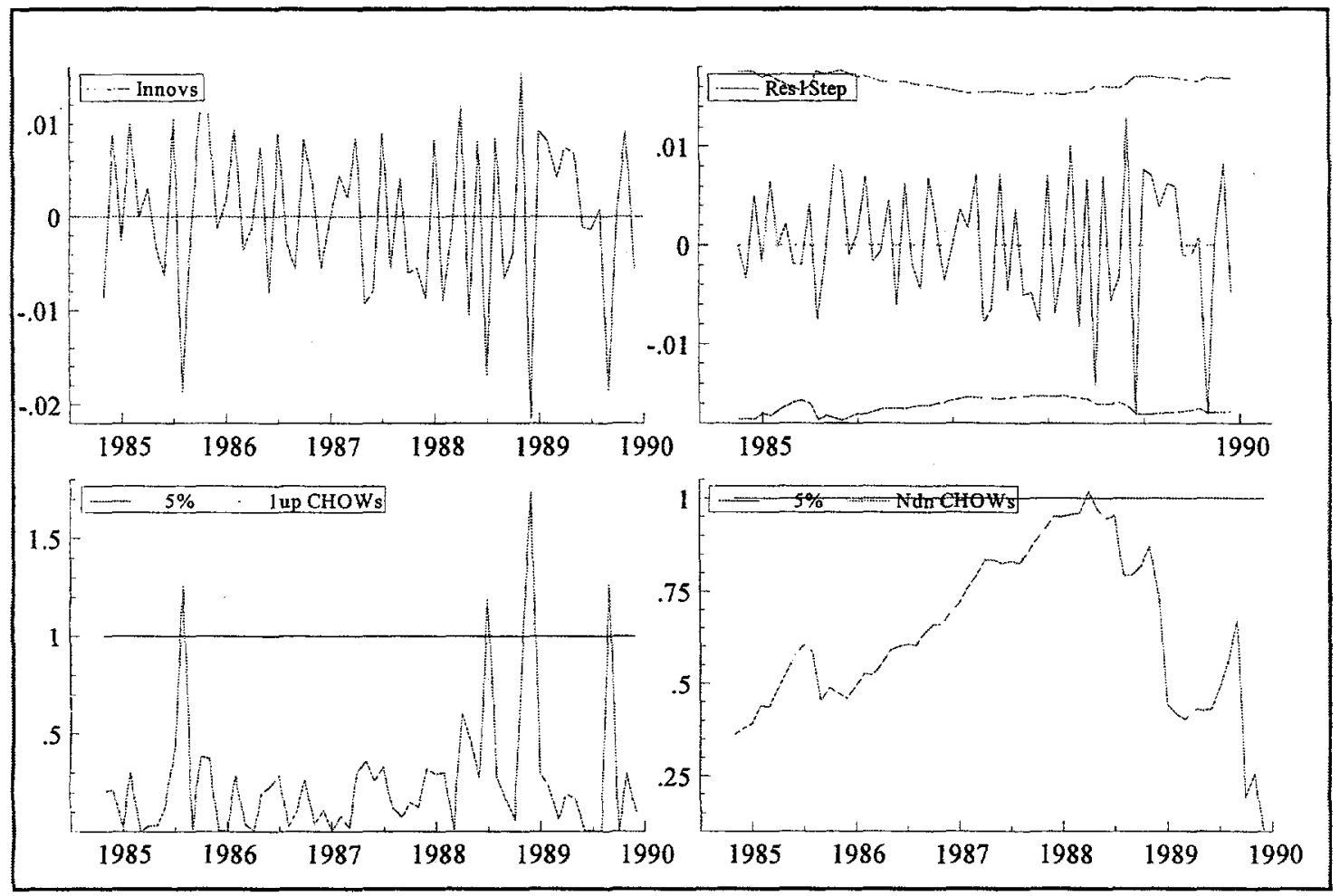


TABLE 6 - DENMARK: Single Equation for Money (Modeling $\Delta(m-p)$ )

\begin{tabular}{|l|c|c|c|c|}
\hline \multicolumn{1}{|c|}{ Variable } & Coefficient & Std. Error & t-value & Hansen Instability \\
\hline Constant & 0.561 & 0.181 & 3.107 & 0.06 \\
\hline$\Delta(m-p)_{t-1}$ & -0.410 & 0.062 & -6.611 & 0.07 \\
\hline$\Delta(m-p)_{t-3}$ & 0.178 & 0.056 & 3.193 & 0.11 \\
\hline$\Delta(m-p)_{t-6}$ & 0.385 & 0.062 & 6.228 & 0.21 \\
\hline$\Delta(m-p)_{t-7}$ & 0.199 & 0.065 & 3.053 & 0.04 \\
\hline$\Delta^{2} p_{t}$ & -0.685 & 0.198 & -3.456 & 0.1 \\
\hline$\Delta^{2} p_{t-5}$ & -0.288 & 0.160 & -1.809 & 0.24 \\
\hline$\Delta y_{t-1}$ & 0.024 & 0.030 & 0.809 & 0.43 \\
\hline$\Delta t_{t}^{D}$ & -0.004 & 0.003 & -1.262 & 0.06 \\
\hline$\Delta I_{t}^{A}$ & -0.005 & 0.002 & -2.984 & 0.11 \\
\hline$\Delta e_{t}$ & -0.301 & 0.133 & -2.262 & 0.05 \\
\hline denECMrM2 & -0.029 & 0.010 & -2.842 & 0.06 \\
\hline denECMinf $t_{t-1}$ & -0.002 & 0.006 & -0.345 & 0.06 \\
\hline
\end{tabular}

Sample: 1977:3-1993:12
$\mathrm{R}^{2}=0.886042$
$F(33,168)=39.583[0.0000]$
$\sigma=0.0116$

$\begin{array}{lll}\text { AR 1- } 7 \mathrm{~F}(7,161) & =1.4047[0.2068] \\ \text { ARCH 7 F }(7,154) & =1.383[0.2162] \\ \text { Normality Chi } 2(2) & =3.5022[0.1736] \\ \text { HETERO F(46,121) } & =0.70941[0.9070]\end{array}$

Hansen Instability Test Results: Variance: 0.101549 Joint (variance \& coefficients): 4.23773 F-CRISIS $(68,100)=1.1544[0.2544]$

FIGURE 6 - DENMARK: Recursive estimation for money demand

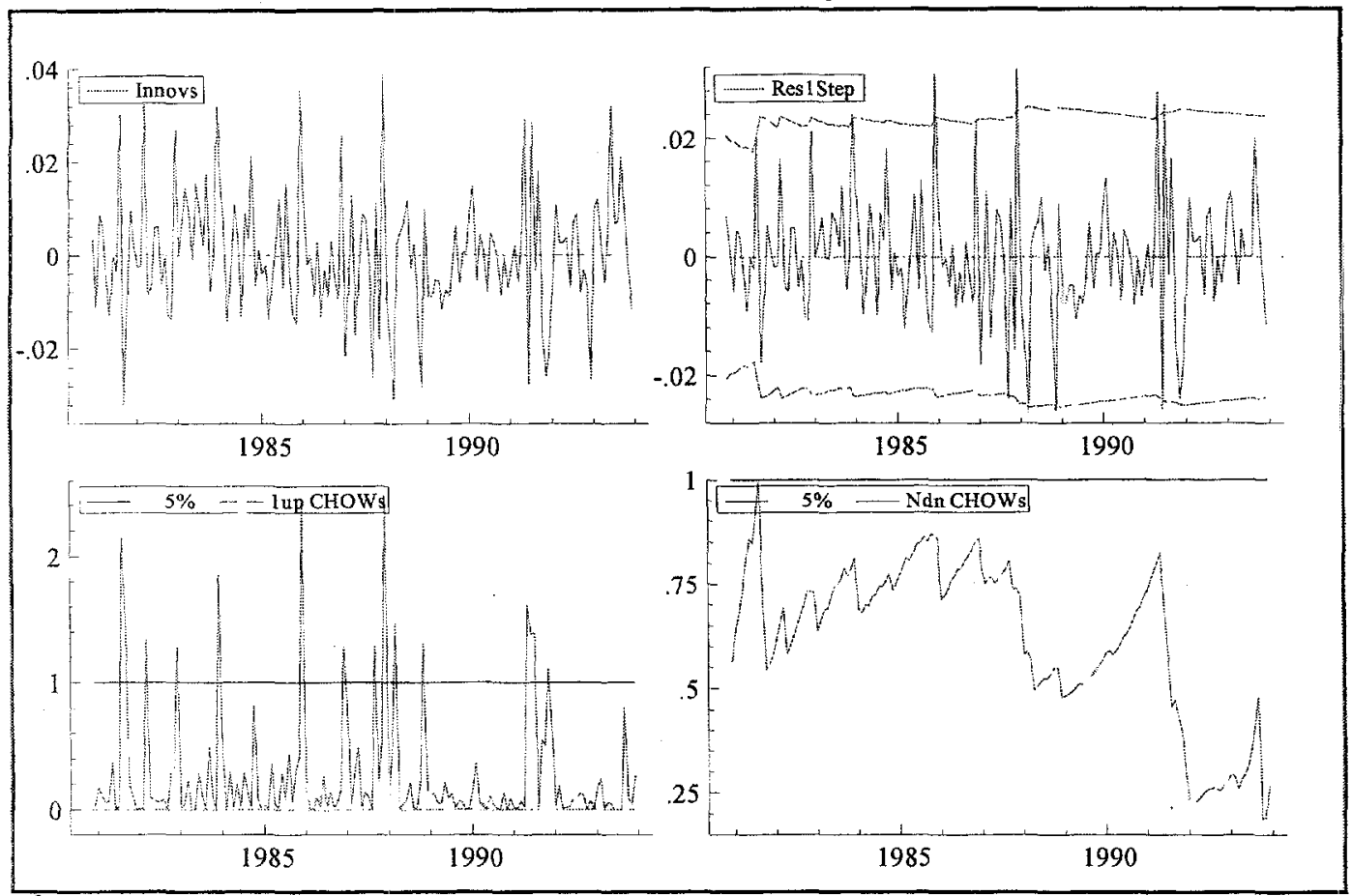

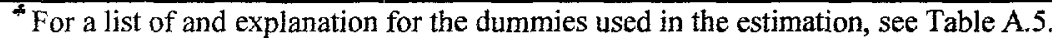


TABLE 7 - JAPAN: Single Equation for Money (Modeling $\Delta(m-p))^{*}$

\begin{tabular}{|l|c|c|c|c|}
\hline \multicolumn{1}{|c|}{ Variable } & Coefficient & Std. Error & t-value & Hansen Instability \\
\hline Constant & 0.047 & 0.006 & 7.808 & 0.18 \\
\hline$\Delta(m-p)_{t-1}$ & -0.251 & 0.058 & -4.320 & 0.35 \\
\hline$\Delta(m-p)_{t-3}$ & 0.116 & 0.049 & 2.395 & 0.1 \\
\hline$\Delta(m-p)_{t-5}$ & 0.209 & 0.049 & 4.273 & 0.04 \\
\hline$\Delta(m-p)_{t-6}$ & 0.185 & 0.051 & 3.635 & 0.09 \\
\hline$\Delta(m-p)_{t-9}$ & 0.197 & 0.050 & 3.965 & 0.06 \\
\hline$\Delta(m-p)_{t-10}$ & -0.119 & 0.051 & -2.317 & 0.17 \\
\hline$\Delta^{2} p_{t}$ & -0.895 & 0.108 & -8.254 & 0.23 \\
\hline$\Delta^{2} p_{t-12}$ & -0.190 & 0.075 & -2.520 & 0.05 \\
\hline$\Delta y_{t}$ & -0.079 & 0.026 & -3.013 & 0.36 \\
\hline$\Delta_{t}^{A}$ & -0.000 & 0.002 & -0.130 & 0.23 \\
\hline$\Delta N_{t}^{O}$ & 0.002 & 0.002 & 1.004 & 0.4 \\
\hline japECMrm2 & -0.012 & 0.002 & -7.595 & 0.15 \\
\hline
\end{tabular}

Sample: 1978:4-1997:12

$\mathrm{R}^{2}=0.681371$

$F(27,209)=16.553[0.0000]$

$\sigma=0.0056$

$\begin{array}{llr}\text { AR I - 7 F }(7,202) & = & 3.4515[0.0016] \\ \text { ARCH } 7 \text { F }(7,195) & = & 0.47052[0.8551] \\ \text { Normality Chi }{ }^{2}(2) & = & 1.3498[0.5092] \\ \text { HETERO F }(39,169) & = & 1.4382[0.0608]\end{array}$

Hansen Instability Test Results: Variance: 0.188812 Joint (variance $\&$ coefficients): 3.49508 F-CRISIS $(93,116)=1.334[0.0704]$

FIGURE 7 - JAPAN: Recursive estimation for money demand

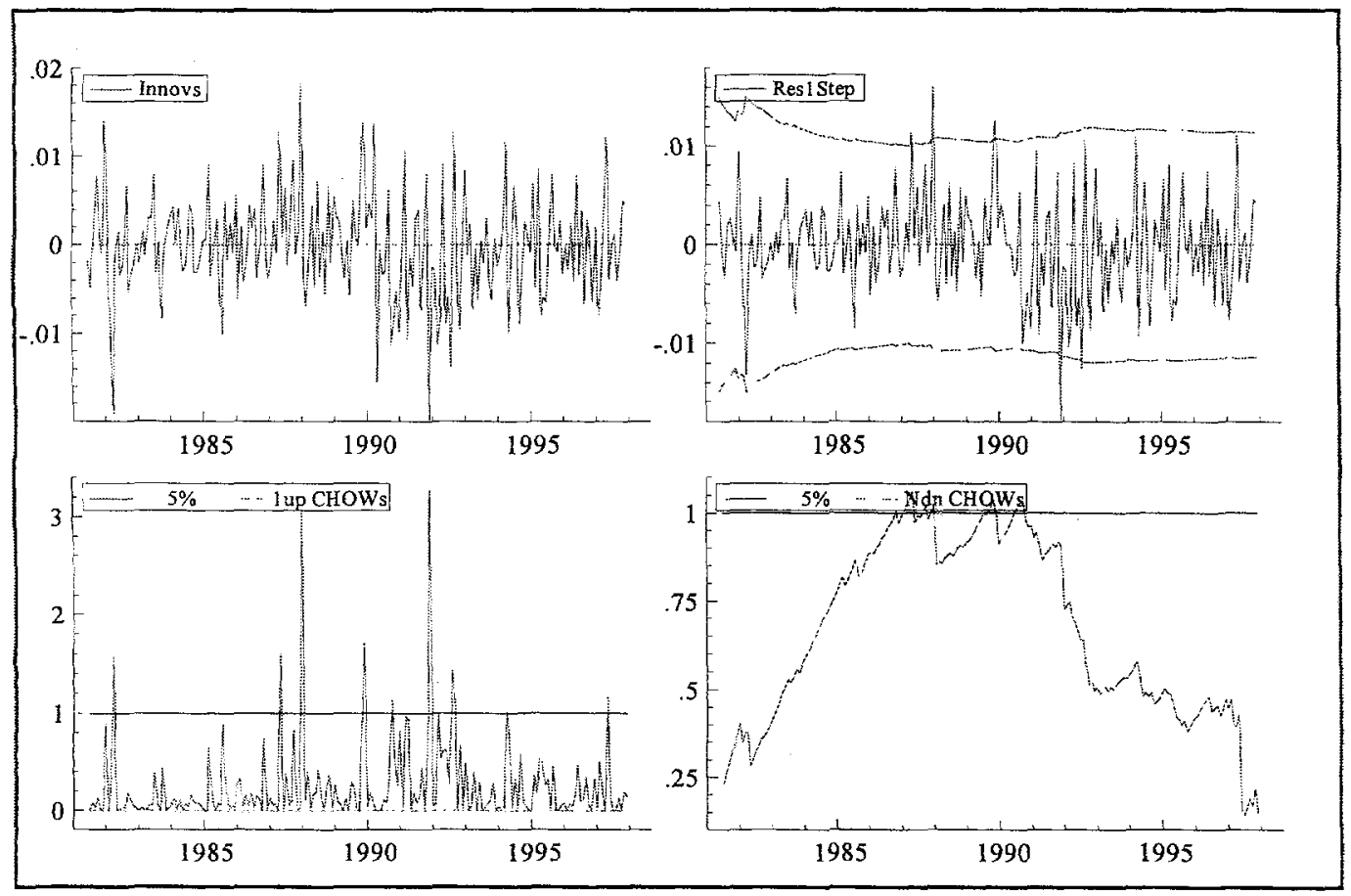

* For a list of and explanation for the dummies used in estimation, see Table A.5.

** Denotes significance at $1 \%$. 
TABLE 8 - KENYA: Single Equation for Money (Modeling $\triangle m)^{*}$

\begin{tabular}{|l|c|c|c|c|}
\hline \multicolumn{1}{|c|}{ Variable } & Coefficient & Std. Error & t-value & Hansen Instability \\
\hline Constant & 4.498 & 0.978 & 4.597 & 0.12 \\
\hline$\Delta m_{t-1}$ & -0.168 & 0.058 & -2.922 & 0.2 \\
\hline$\Delta m_{t-3}$ & 0.231 & 0.056 & 4.162 & 0.16 \\
\hline$\Delta p_{t}$ & 0.129 & 0.098 & 1.325 & 0.1 \\
\hline$\Delta y_{t}$ & -1.522 & 0.870 & -1.750 & 0.07 \\
\hline$\Delta I_{t}^{A}$ & -0.002 & 0.001 & -3.813 & 0.1 \\
\hline$\Delta I_{t-2}^{A}$ & -0.002 & 0.001 & -2.435 & 0.02 \\
\hline$\Delta I_{t-2}^{O}$ & 0.010 & 0.002 & 4.762 & 0.11 \\
\hline$\Delta e_{t-2}$ & -0.139 & 0.056 & -2.495 & 0.05 \\
\hline$\Delta e_{t-3}$ & -0.148 & 0.055 & -2.663 & 0.39 \\
\hline KenECMnM2 $_{t-1}$ & -0.065 & 0.014 & -4.616 & 0.08 \\
\hline KenECMgdp $\mathrm{p}_{t-1}$ & -0.191 & 0.041 & -4.580 & 0.12 \\
\hline KenECMispr $r_{t-1}$ & -0.016 & 0.003 & -4.639 & 0.03 \\
\hline
\end{tabular}

Sample: 1977:2-1996:12

$\mathrm{R}^{2}=0.473089$

$\mathrm{F}(30,208)=6.2251[0.0000] \quad \sigma=0.0201$

AR 1- 7F( 7,201)

ARCH 7 F ( 7,194)

Normality $\mathrm{Chi}^{2}(2)$

HETERO F(42,165)

$=1.2203[0.2930]$

$=1.3342[0.2360]$

$=0.33438[0.8460]$

$=0.69782[0.9141]$

Hansen Instability Tests Results: Variance: 0.095519 Joint (variance $\&$ coefficients): 3.70518

F-CRISIS $(58,106)=1.0628[0.3873]$

FIGURE 8 - KENYA: Recursive estimation for money demand

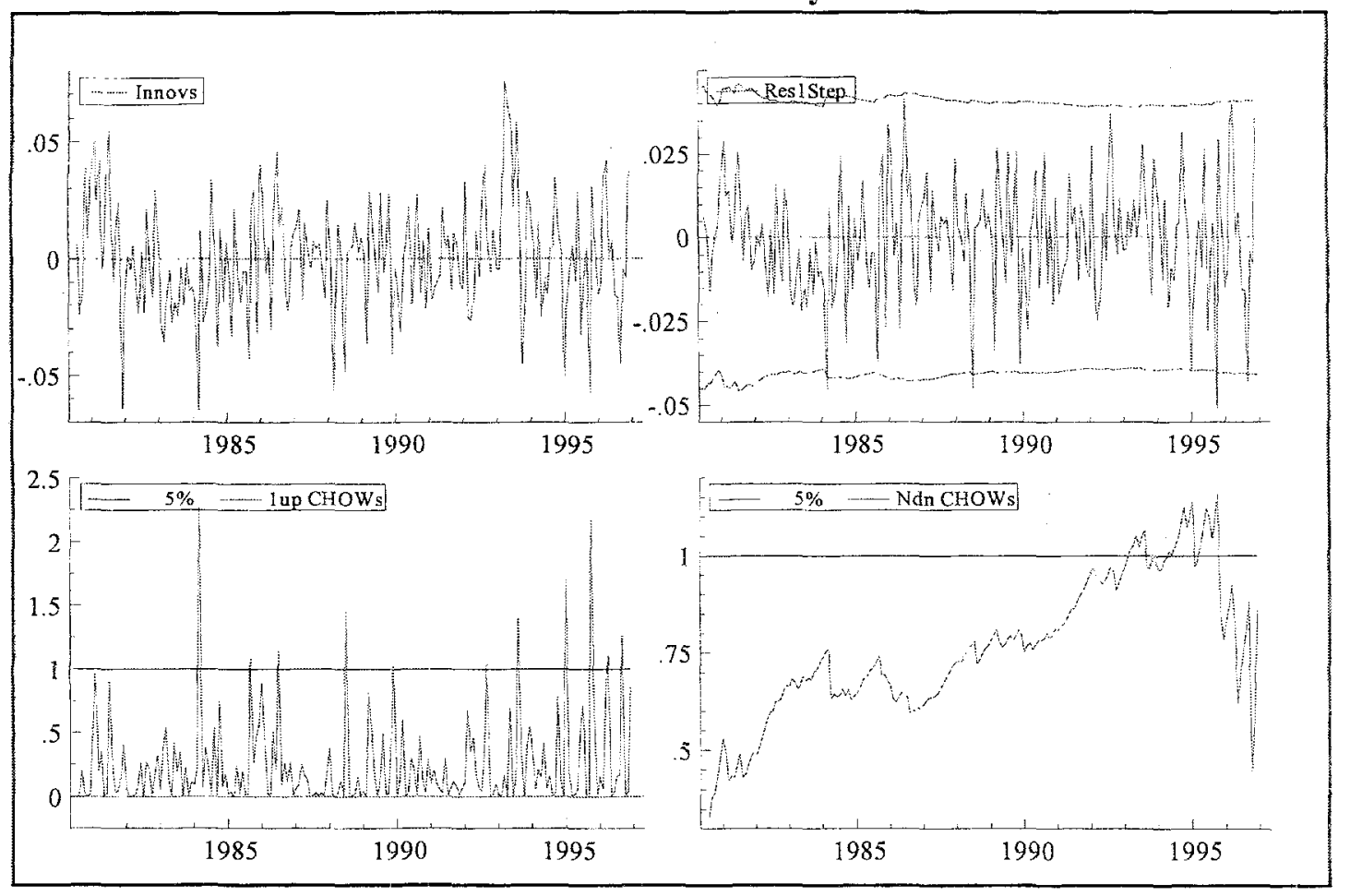

* For a list of and explanation for the dummies used in estimation, see Table A.5. 
TABLE 9 - MALAYSIA: Single Equation for Money (Modeling $\Delta(m-p))^{*}$

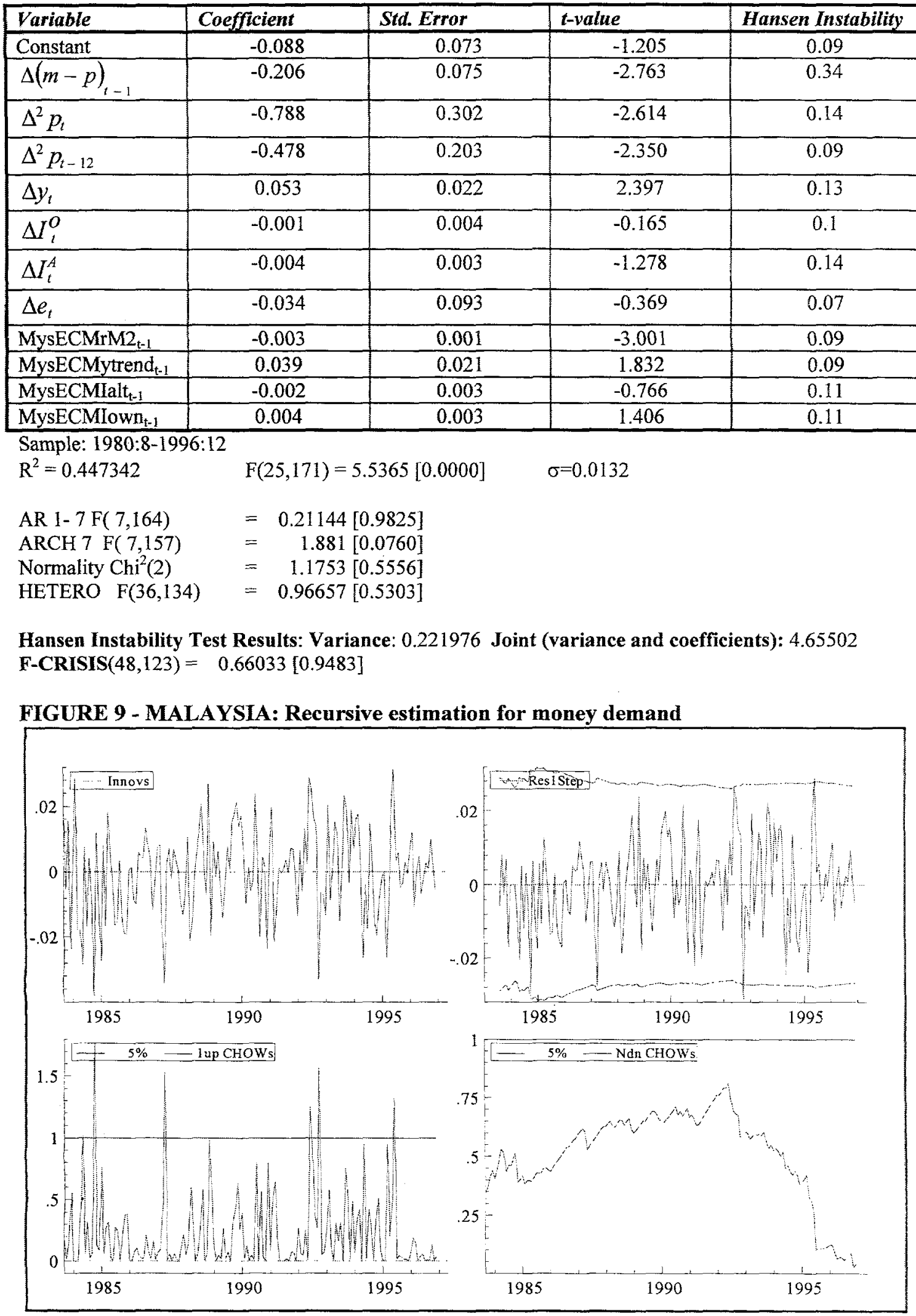

For a list of and explanation for the dummies used in estimation, see Tabie A.5. 
TABLE 10 - URUGUAY: Single Equation for Money (Modeling $\Delta(m-p)$ )*

\begin{tabular}{|c|c|c|c|c|}
\hline Variable & Coefficient & Std. Error & t-value & Hansen Instability \\
\hline Constant & 0.529 & 0.067 & 7.846 & 0.27 \\
\hline$\Delta(m-p)_{t-2}$ & 0.132 & 0.037 & 3.578 & 0.07 \\
\hline$\Delta(m-p)_{t-6}$ & 0.109 & 0.036 & 3.022 & 0.2 \\
\hline$\Delta(m-p)_{t-12}$ & 0.133 & 0.041 & 3.205 & 0.2 \\
\hline$\Delta^{2} p_{t}$ & -0.875 & 0.094 & -9.313 & 0.07 \\
\hline$\Delta^{2} p_{t-5}$ & -0.187 & 0.068 & -2.742 & 0.08 \\
\hline$\Delta^{2} p_{t-8}$ & -0.169 & 0.077 & -2.191 & 0.02 \\
\hline$\Delta^{2} p_{t-9}$ & -0.238 & 0.084 & -2.831 & 0.1 \\
\hline$\Delta^{2} p_{t-10}$ & -0.472 & 0.094 & -4.998 & 0.04 \\
\hline$\Delta^{2} p_{t-11}$ & -0.351 & 0.092 & -3.830 & 0.12 \\
\hline$\Delta^{2} p_{t-12}$ & -0.158 & 0.068 & -2.322 & 0.07 \\
\hline$\Delta y_{t}$ & 0.066 & 0.042 & 1.565 & 0.28 \\
\hline$\Delta I_{t-7}^{O}$ & 0.001 & 0.000 & 2.189 & 0.1 \\
\hline$\Delta e_{t}$ & 0.483 & 0.065 & 7.424 & 0.4 \\
\hline$\Delta e_{t-1}$ & -0.382 & $\overline{0.032}$ & -11.960 & 0.23 \\
\hline$\Delta e_{t-2}$ & 0.084 & 0.024 & $\overline{3.471}$ & $0.69^{*}$ \\
\hline$\Delta e_{t-4}$ & -0.071 & 0.020 & -3.493 & 0.12 \\
\hline$\Delta e_{t-8}$ & -0.060 & 0.022 & -2.777 & 0.19 \\
\hline UruECMrM2 $2_{\mathrm{t}-1}$ & -0.040 & 0.006 & -7.064 & 0.27 \\
\hline $\begin{array}{l}\text { Sample: } 1982: 9-199 \\
\mathrm{R}^{2}=0.897336\end{array}$ & \multicolumn{2}{|c|}{$F(37,146)=34.49[0.0000]$} & $\sigma=0.0147$ & \\
\hline $\begin{array}{l}\text { AR 1- } 7 F(7,139) \\
\text { ARCH } 7 F(7,132) \\
\text { Normality Chi }{ }^{2}(2) \\
\mathrm{Xi}^{\wedge} 2 \mathrm{~F}(55,90)\end{array}$ & $\begin{array}{l}=1.238 \\
=1.498 \\
=1.761 \\
=1.269\end{array}$ & & & \\
\hline
\end{tabular}

Hansen Instability test results: Variance: 0.226654 Joint (variance \& coefficients): 4.96548

F-CRISIS $(38,108)=2.2689[0.0005] * *$

\footnotetext{
* For a list of and explanation for the dummies used in estimation, see Table A.5.

** Denotes significance at $1 \%$.
} 


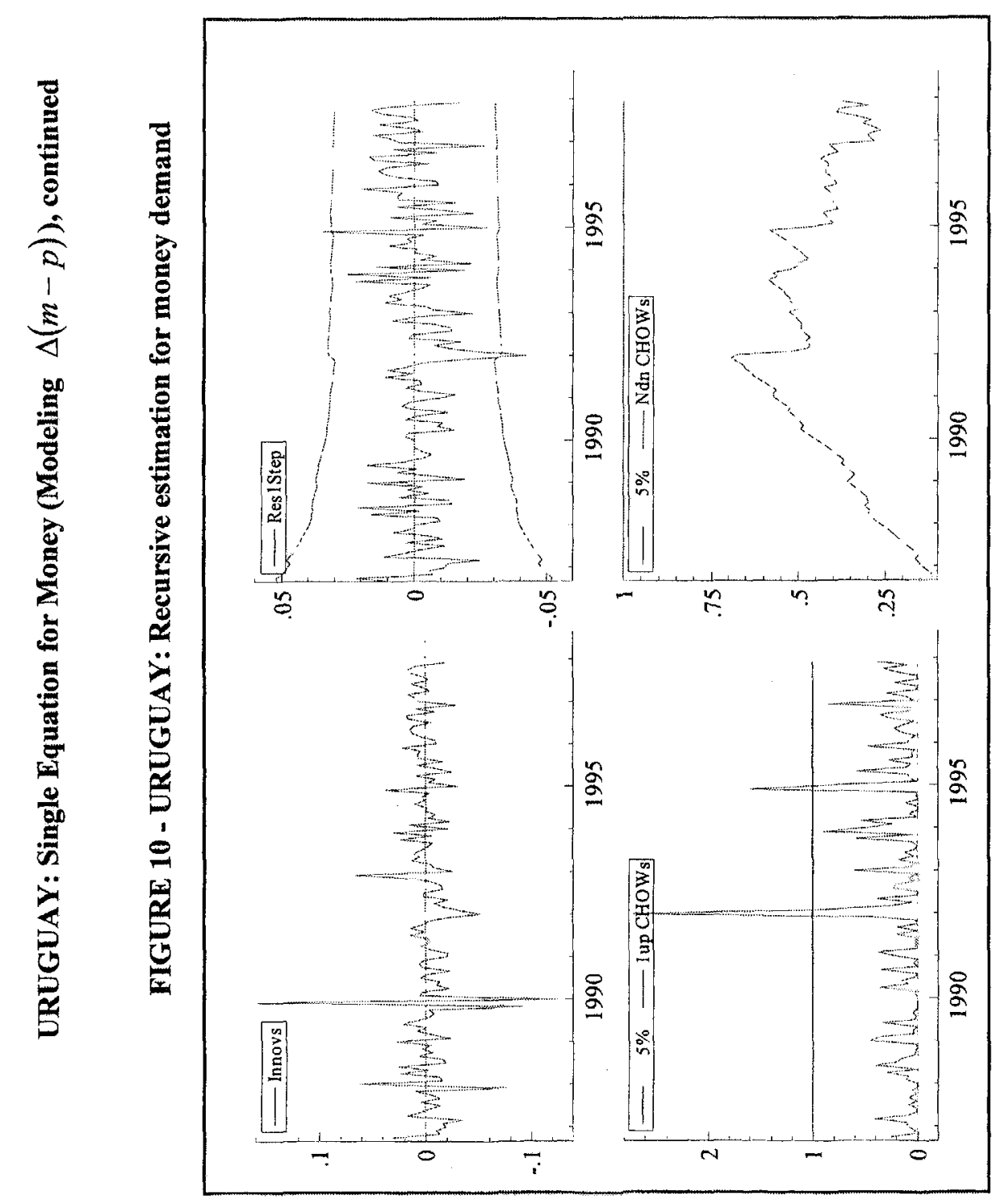


Table 11: Summary Table for Money Demand Stability Tests

\begin{tabular}{|c|c|c|c|c|c|}
\hline \multirow[t]{2}{*}{ Country } & \multirow{2}{*}{$\begin{array}{c}\text { Recursive Least } \\
\text { Squares } \\
\text { Chow Tests }\end{array}$} & \multicolumn{2}{|c|}{ Hansen Test } & \multicolumn{2}{|c|}{$\overline{\text { F-Crisis }}$} \\
\hline & & Variance & Joint & Statistic & p-value \\
\hline Chile & stable $^{\mathrm{a}}$ & 0.163 & 3.999 & 1.343 & {$[0.098]$} \\
\hline \multicolumn{6}{|l|}{ Colombia } \\
\hline Entire Sample & unstable & $0.714^{*}$ & 4.758 & 0.572 & {$[0.993]$} \\
\hline $1982: 3-1989: 12$ & stable $^{6}$ & 0.086 & 4.29 & & \\
\hline Denmark & stable & 0.102 & 4.238 & 1.154 & {$[0.254]$} \\
\hline Japan & stable & 0.189 & 3.495 & 1.334 & {$[0.070]$} \\
\hline Kenya & stable & 0.096 & 3.705 & 1.063 & {$[0.387]$} \\
\hline Malaysia & stable & 0.222 & 4.655 & 0.66 & {$[0.948]$} \\
\hline Uruguay & stable $^{a}$ & 0.227 & 4.965 & 2.269 & {$[0.001]^{* *}$} \\
\hline
\end{tabular}

${ }^{\mathrm{a}}$ The recursive estimation does not include the crisis period.

${ }^{\mathrm{b}}$ The overall instability in the sample comes from the period after the crisis.

$*, *$ Denotes significance at $5 \%$ and $1 \%$, respectively.

Table 12: Summary Table for Price Equation Stability Tests

\begin{tabular}{|l|l|l|l|l|l|}
\hline Country & $\begin{array}{c}\text { Recursive Least } \\
\text { Squares } \\
\text { Chow Tests }\end{array}$ & \multicolumn{2}{c|}{ Hansen Test } & \multicolumn{2}{c|}{ F-Crisis } \\
& Variance & Joint & Statistic & p-value \\
\hline Chile & Stable & 0.298 & 5.674 & 0.963 & {$[0.565]$} \\
\hline Colombia & Stable & $1.035^{*}$ & 6.754 & 2.545 & {$[0.000]^{* *}$} \\
\hline Denmark & Stable & 0.259 & 4.813 & 0.754 & {$[0.888]$} \\
\hline Japan & Stable & $0.523^{*}$ & 7.961 & 0.855 & {$[0.779]$} \\
\hline Kenya & & & & & \\
\hline Entire Sample & Unstable & $0.491^{*}$ & 4.327 & 1.439 & {$[0.037]^{*}$} \\
\hline 1980s & & & & 0.748 & {$[0.884]$} \\
\hline 1990s & & & & 2.163 & {$[0.001]^{* *}$} \\
\hline Malaysia & Stable & 0.355 & 5.315 & 0.736 & {$[0.886]$} \\
\hline Uruguay & Stable & 0.21 & 5.568 & 2.142 & {$[0.001]^{* *}$} \\
\hline
\end{tabular}

${ }^{\mathrm{a}}$ The recursive estimation does not include the crisis period.

*, ** Denotes significance at $5 \%$ and $1 \%$, respectively. 
TABLE 13 - CHILE: Single Equation for Prices (Modeling $\Delta^{2} \mathbf{p}$ )

\begin{tabular}{|c|c|c|c|c|}
\hline Variable & Coefficient & Std. Error & t-value & Hansen Instability \\
\hline Constant & -0.077 & 0.072 & -1.076 & 0.23 \\
\hline$\Delta^{2} p_{t-2}$ & -0.175 & 0.058 & -2.996 & 0.03 \\
\hline$\Delta^{2} m_{t-2}$ & 0.027 & 0.013 & 2.124 & 0.36 \\
\hline$\Delta y_{t}$ & -0.016 & 0.012 & -1.331 & 0.1 \\
\hline$\Delta I_{t-5}^{O}$ & -0.000 & 0.000 & -2.438 & 0.1 \\
\hline$\Delta I_{t-6}^{O}$ & -0.000 & 0.000 & -2.346 & 0.09 \\
\hline$\Delta e_{i}$ & 0.085 & 0.028 & 3.044 & 0.17 \\
\hline$\Delta p_{i}^{*}$ & 0.799 & 0.247 & 3.238 & 0.11 \\
\hline$\Delta^{2} w_{l}$ & -0.020 & 0.014 & -1.427 & 0.05 \\
\hline$\Delta u_{t}$ & -0.019 & 0.008 & -2.383 & 0.06 \\
\hline$\Delta s p_{t}$ & 0.004 & 0.008 & 0.559 & 0.16 \\
\hline ChiECMrM2 $2_{t-1}$ & -0.000 & 0.005 & -0.068 & 0.27 \\
\hline ChiECMytrend $_{t-1}$ & 0.004 & 0.010 & 0.374 & 0.23 \\
\hline ChiECMIown $_{\mathrm{t}-1}$ & 0.000 & 0.000 & 1.978 & 0.25 \\
\hline ChiECMrPPP $_{t-1}$ & -0.009 & 0.003 & -2.724 & 0.15 \\
\hline ChiECMrwage $_{t-1}$ & 0.005 & 0.010 & 0.471 & 0.31 \\
\hline
\end{tabular}

Sample: 1978:3-1993:11

$R^{2}=0.724088 \quad F(32,149)=12.22[0.0000]$

AR 1- $7 \mathrm{~F}(7,142) \quad=1.9657[0.0638]$

$\mathrm{ARCH} 7 \mathrm{~F}(7,135)=0.72714[0.6492]$

Normality $\mathrm{Chi}^{2}(2) \quad=\quad 2.4586[0.2925]$

HETERO $F(47,101) \quad=0.63269[0.9591]$

Hansen Instability Tests: Variance: 0.297906 Joint (variance \& coefficients): 5.67416

F-CRISIS $(77,72)=0.96332[0.5648]$

\section{FIGURE 13 - CHILE: Recursive estimation for price equation}

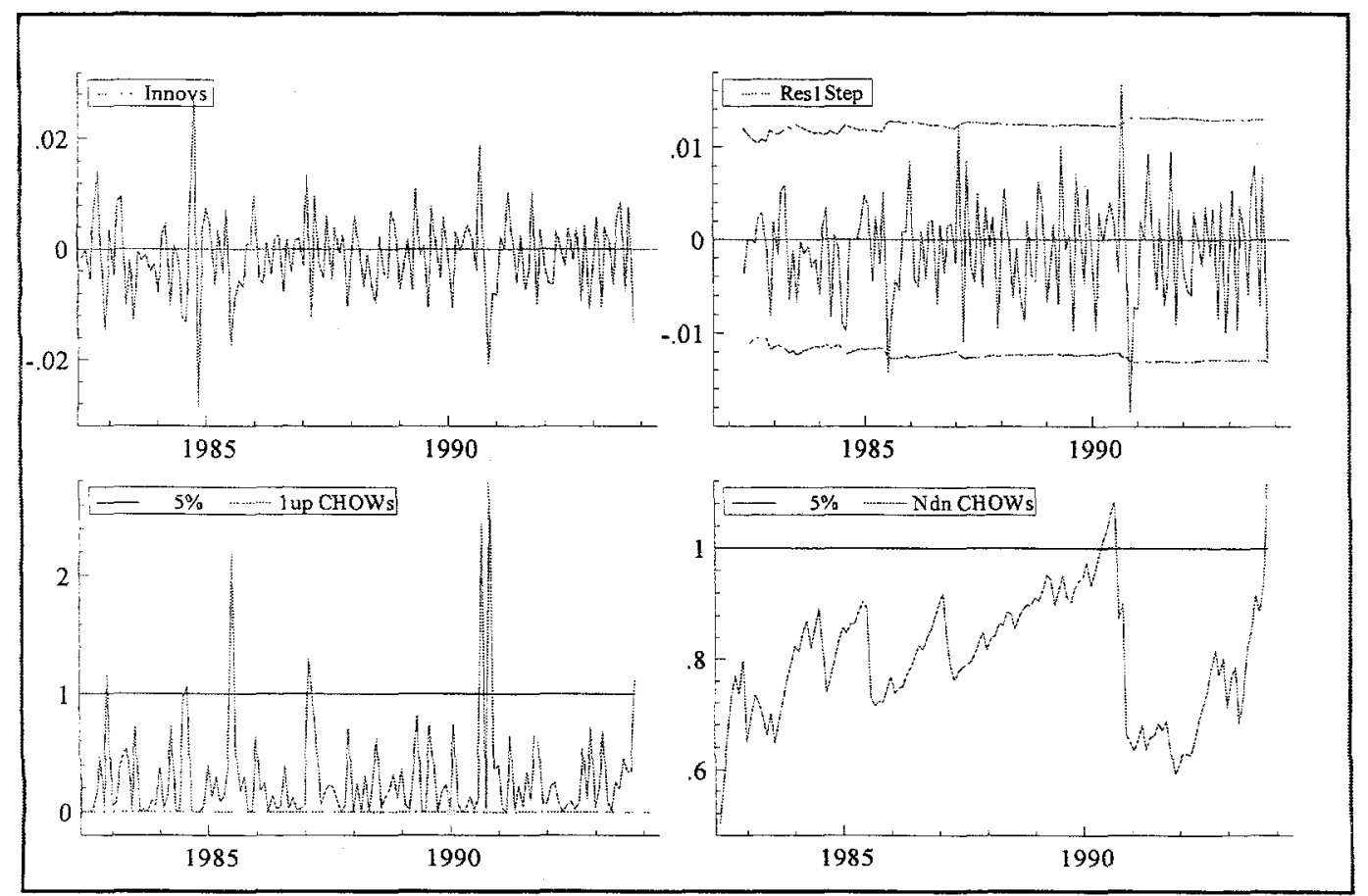

*For a list of and explanation for the dummies used in estimation, see Table A.5. 
TABLE 14 - COLOMBIA: Single Equation for Prices (Modeling $\Delta p$ )

\begin{tabular}{|c|c|c|c|c|}
\hline Variable & Coefficient & Std. Error & t-value & Hansen Instability \\
\hline Constant & -0.017 & 0.072 & -0.234 & 0.04 \\
\hline$\Delta p_{t-1}$ & 0.405 & 0.068 & 5.920 & 0.05 \\
\hline$\Delta p_{t-11}$ & 0.213 & 0.074 & 2.864 & 0.05 \\
\hline$\Delta p_{t-12}$ & -0.263 & 0.074 & -3.556 & 0.06 \\
\hline$\Delta m_{t-1}$ & 0.006 & 0.034 & 0.164 & 0.18 \\
\hline$\Delta y_{l}$ & -0.000 & 0.011 & -0.004 & 0.17 \\
\hline$\Delta I_{t}^{o}$ & 0.000 & 0.000 & 1.398 & 0.27 \\
\hline$\Delta V_{t}^{*}$ & -0.003 & 0.001 & -2.811 & 0.03 \\
\hline$\Delta I_{t-7}^{*}$ & -0.003 & 0.001 & -2.706 & 0.22 \\
\hline$\Delta p_{t-2}^{*}$ & $0 . \overline{389}$ & 0.247 & 1.572 & 0.12 \\
\hline$\Delta p_{t-3}^{*}$ & $0 . \overline{743}$ & 0.295 & 2.514 & 0.09 \\
\hline$\Delta p_{t-4}^{*}$ & -0.404 & 0.257 & -1.569 & 0.07 \\
\hline$\Delta e_{t}$ & 0.003 & 0.028 & 0.122 & 0.03 \\
\hline$\Delta w_{l}$ & 0.089 & 0.042 & 2.144 & 0.22 \\
\hline$\Delta u_{t}$ & -0.000 & 0.010 & -0.032 & 0.06 \\
\hline$\Delta s p_{t}$ & 0.007 & 0.006 & 1.215 & 0.25 \\
\hline ColECMnwage $_{t-1}$ & 0.034 & 0.020 & 1.737 & 0.04 \\
\hline ColECMnM2 $2_{t-1}$ & -0.002 & 0.009 & -0.216 & 0.04 \\
\hline ColECMIown $_{t-1}$ & 0.000 & 0.000 & 1.102 & 0.04 \\
\hline ColECMnPPP $_{t-3}$ & -0.006 & 0.003 & -1.797 & 0.04 \\
\hline ColECMIfor $_{t-1}$ & -0.000 & 0.000 & -0.685 & 0.04 \\
\hline $\begin{array}{l}\text { Sample: } 1982: 3-1998: 6 \\
R^{2}=0.762338 \\
F(42,153)=11.685[0.0000]\end{array}$ & $\begin{array}{l}\text { A } \\
\text { A } \\
N \\
\mathrm{~N} \\
\mathrm{H}\end{array}$ & $\begin{array}{l}146) \\
139) \\
i^{2}(2) \\
63,89)\end{array}$ & $\begin{array}{l}1.8252[0.0866] \\
1.7248[0.1079] \\
4.6588[0.0974] \\
1.3777[0.0816]\end{array}$ & \\
\hline
\end{tabular}

Hansen Instability Test Results: Variance: $1.0347^{* *}$ Joint (variance \& coefficients): 6.754

F-CRISIS $(70,83)=2.5448[0.0000]^{* *}$

FIGURE 14 - COLOMBIA: Recursive estimation for price equation

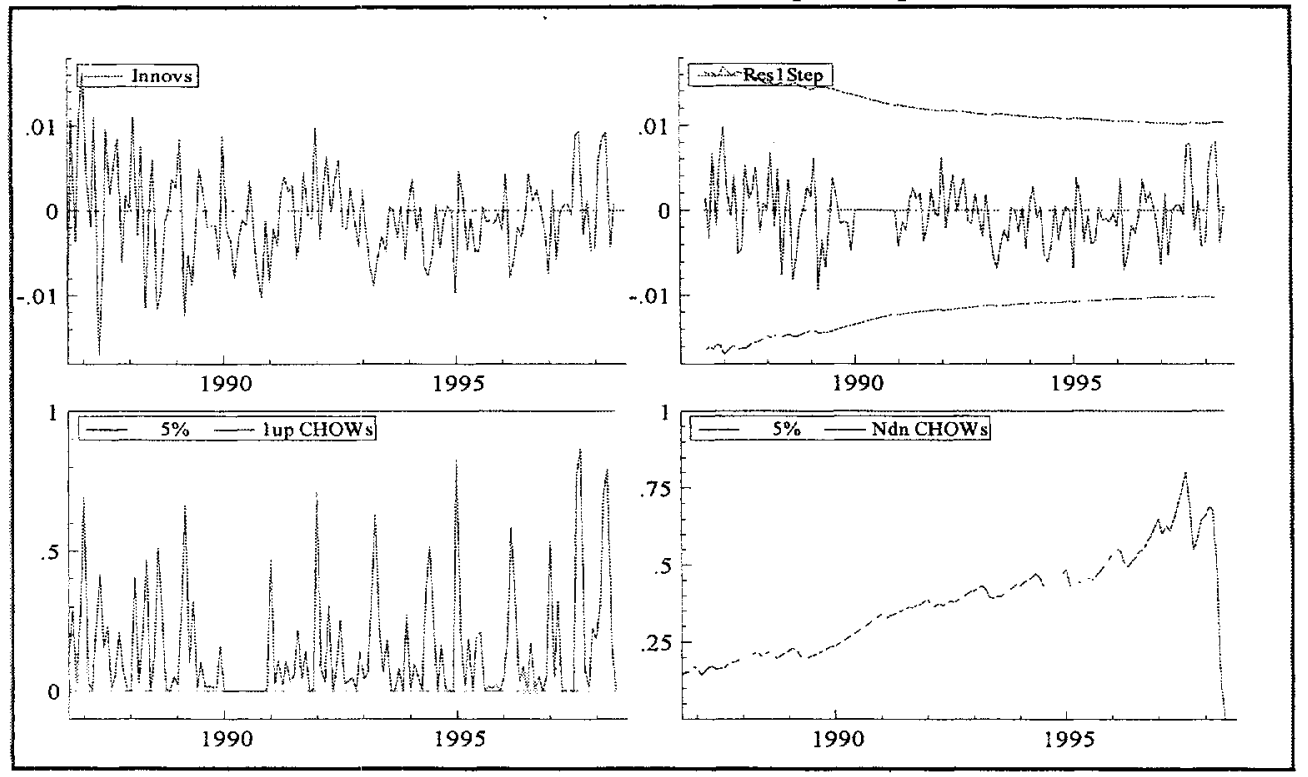

* For a list of and explanation for the dummies used in estimation, see Table A.5. ** Denotes significance at $1 \%$. 
TABLE 15 - DENMARK: Single Equation for Prices (Modeling $\Delta^{2} p$ )

\begin{tabular}{|c|c|c|c|c|}
\hline Variable & Coefficient & Std. Error & t-value & Hansen Instability \\
\hline Constant & 0.091 & 0.049 & 1.844 & 0.05 \\
\hline$\Delta^{2} p_{1-1}$ & 0.208 & 0.065 & 3.215 & 0.26 \\
\hline$\Delta^{2} m_{t-12}$ & 0.024 & 0.009 & 2.720 & $0.55^{*}$ \\
\hline$\Delta y_{t-5}$ & 0.014 & 0.007 & 1.949 & 0.19 \\
\hline$\Delta I_{t-1}^{O}$ & 0.003 & 0.001 & 3.678 & 0.4 \\
\hline$\Delta I_{t}^{A}$ & -0.000 & 0.001 & -0.524 & 0.14 \\
\hline$\Delta e_{t}$ & 0.008 & 0.035 & 0.218 & 0.1 \\
\hline$\Delta p_{1}^{*}$ & 0.330 & 0.088 & 3.738 & 0.26 \\
\hline$\Delta I_{t}^{*}$ & 0.002 & 0.001 & 1.596 & 0.08 \\
\hline$\Delta u_{t-5}$ & 0.023 & 0.006 & 3.742 & 0.05 \\
\hline$\Delta u_{t-6}$ & 0.022 & 0.006 & 3.468 & 0.38 \\
\hline$\Delta u_{t-12}$ & 0.025 & 0.006 & 3.889 & 0.09 \\
\hline$\Delta^{2} w_{i}$ & 0.035 & 0.020 & 1.718 & 0.07 \\
\hline denECMrM2 $2_{\mathrm{t}-1}$ & -0.007 & 0.003 & -2.505 & 0.05 \\
\hline denECMinfl $_{\mathrm{t}-1}$ & -0.004 & 0.002 & -2.408 & 0.06 \\
\hline denECMrwage ${ }_{t-1}$ & -0.005 & 0.001 & -3.187 & 0.05 \\
\hline denECMrPPP ${ }_{\mathrm{t}-1}$ & -0.025 & 0.008 & -3.258 & 0.04 \\
\hline denECMuip $_{t-1}$ & 0.000 & 0.000 & 2.998 & 0.06 \\
\hline
\end{tabular}

Sample:1977:3-1993:12

$\mathrm{R}^{2}=0.852827$

$F(45,156)=20.088[0.0000]$

AR $1-7 \mathrm{~F}(7,149)$

ARCH 7 F ( 7,142)

Normality $\mathrm{Chi}^{2}(2)$

HETERO $F(63,92)$
$=0.94918[0.4707]$

$=1.3522[0.2303]$

$=5.3779[0.0680]$

$=1.0987[0.3368]$

Hansen Instability Test Results: Variance: 0.258881 Joint (variance $\&$ coefficients): 4.81306

F-CRISIS $(68,88)=0.75377[0.8878]$

FIGURE 15 - DENMARK: Recursive estimation for price equation

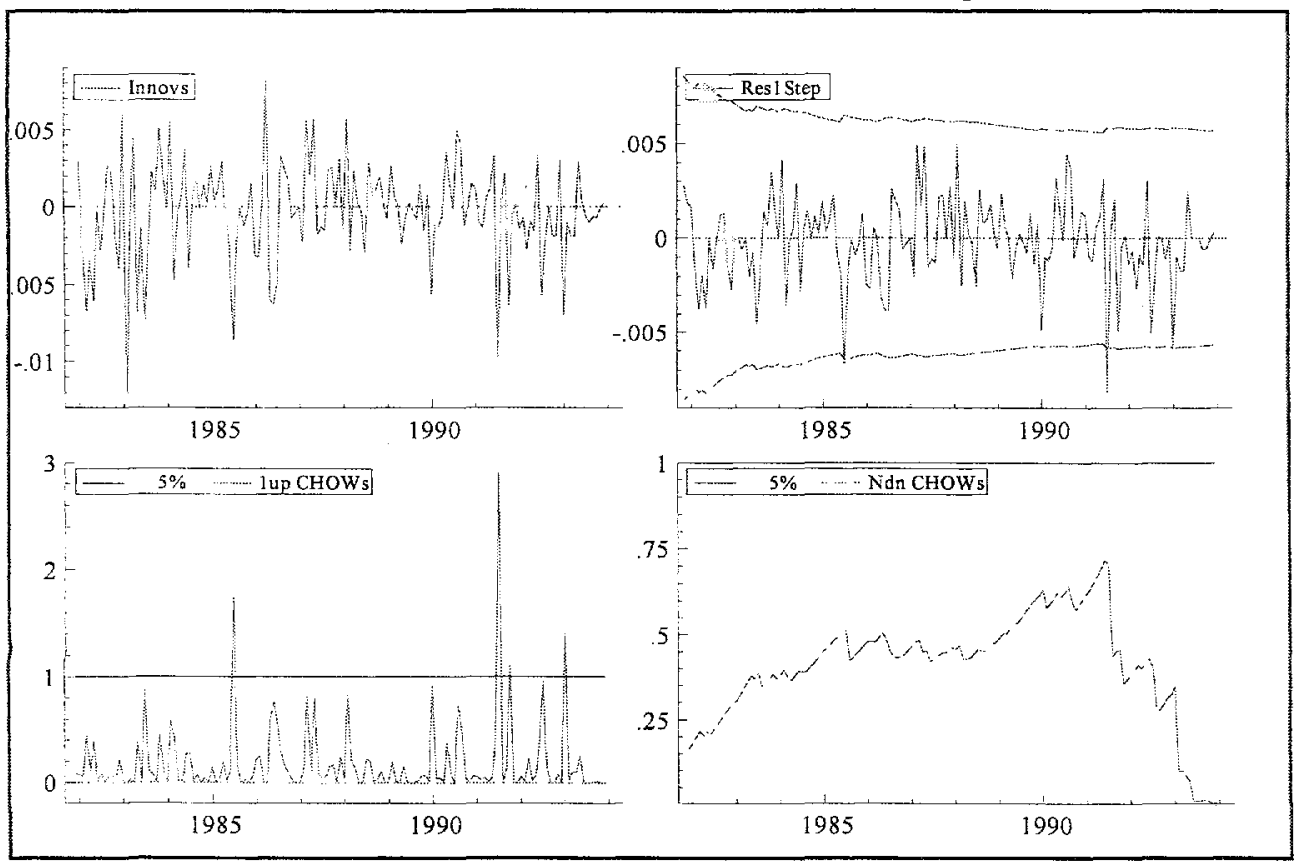

* For a list of and explanation for the dummies used in estimation, see Table A.5. * Denotes significance at $5 \%$. 
TABLE 16 - JAPAN: Single Equation for Prices (Modeling $\left.\Delta^{2} p\right)$

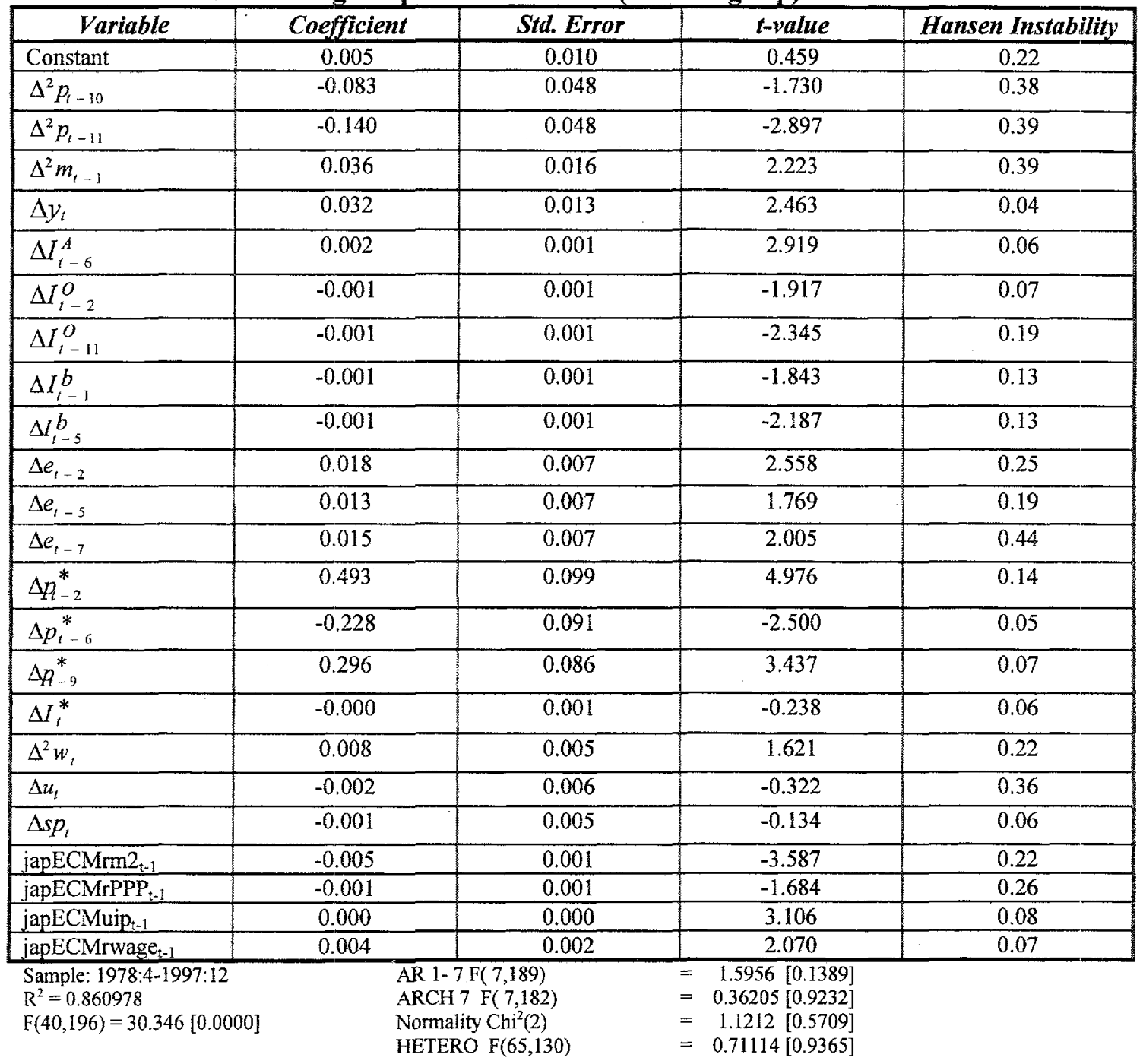

Hansen Instability Test Results: Variance: $0.523257^{*}$ Joint (variance \& coefficients): 7.96058

F-CRISIS $(93,103)=0.85501[0.7786]$

FIGURE 16 - JAPAN: Recursive estimation for price equation

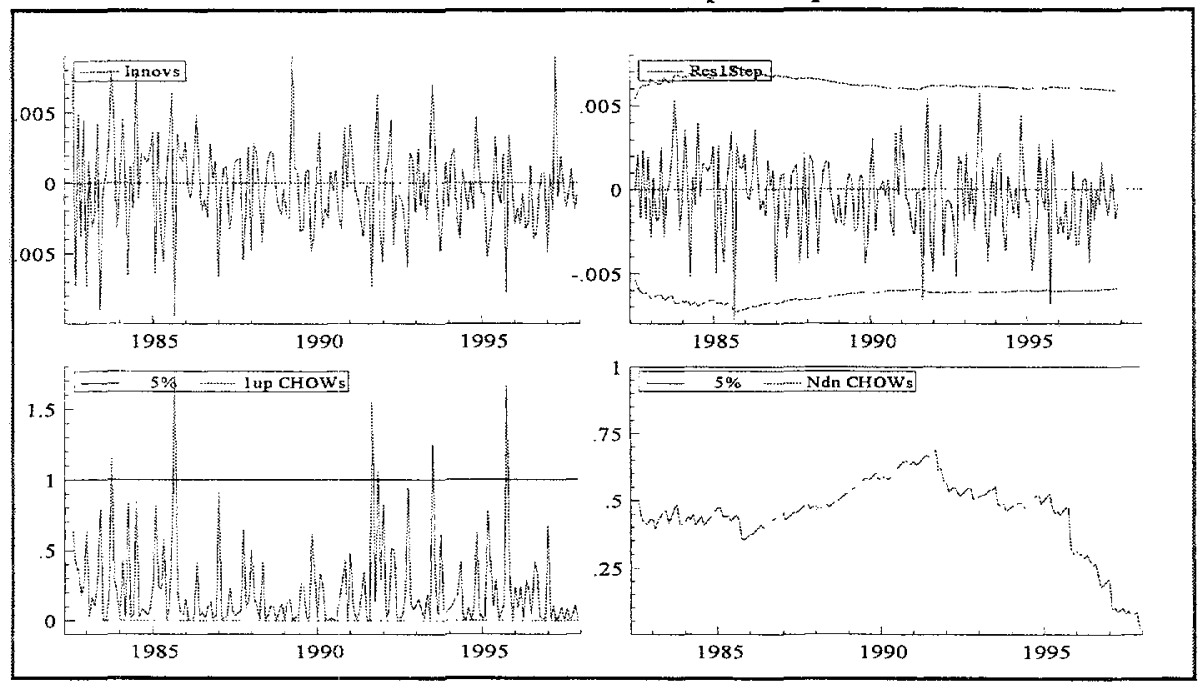


TABLE 17 - KENYA: Single Equation for Prices (Modeling $\Delta \mathrm{p}$ )*

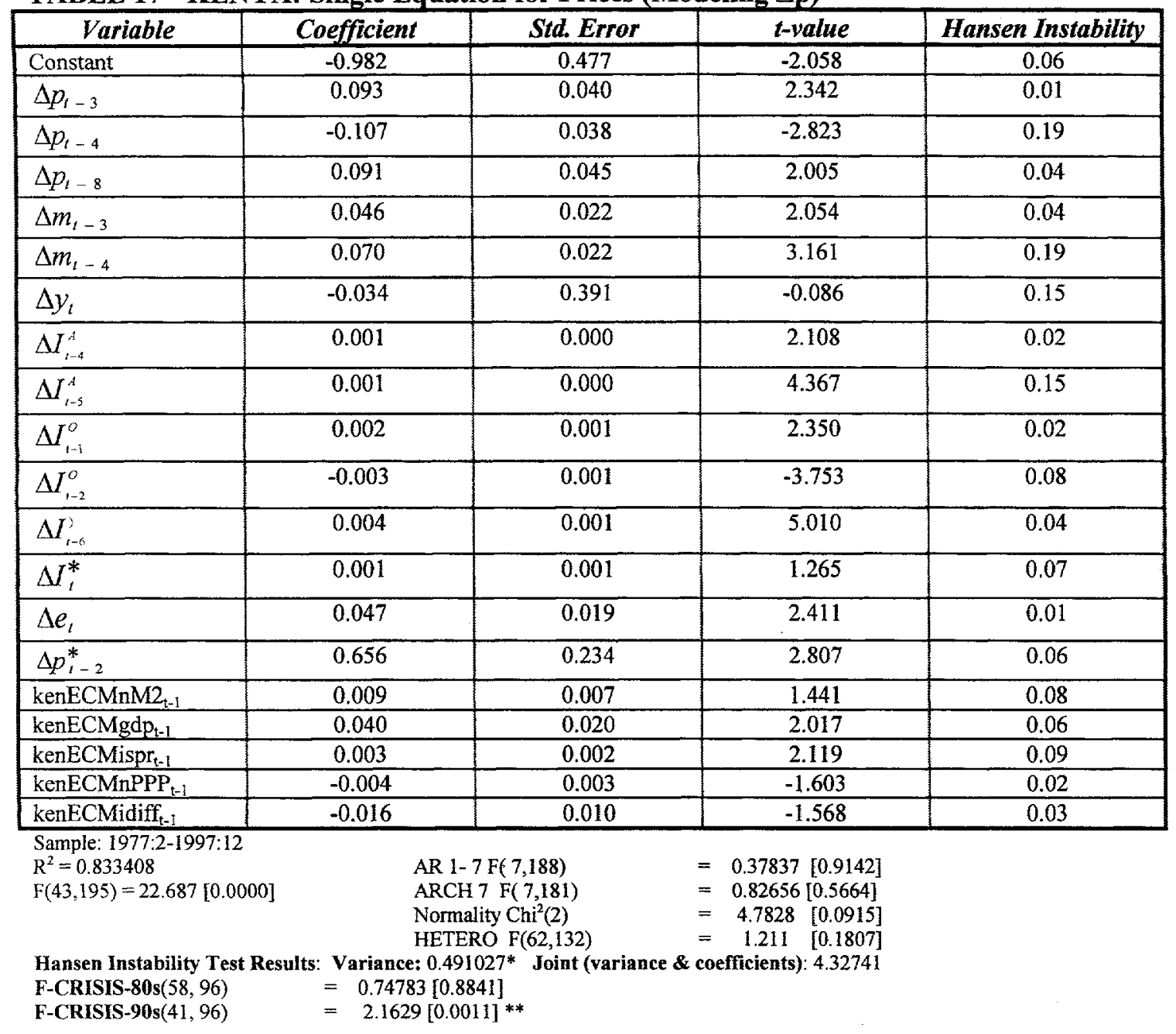

FIGURE 17 - KENYA: Recursive estimation for price equation

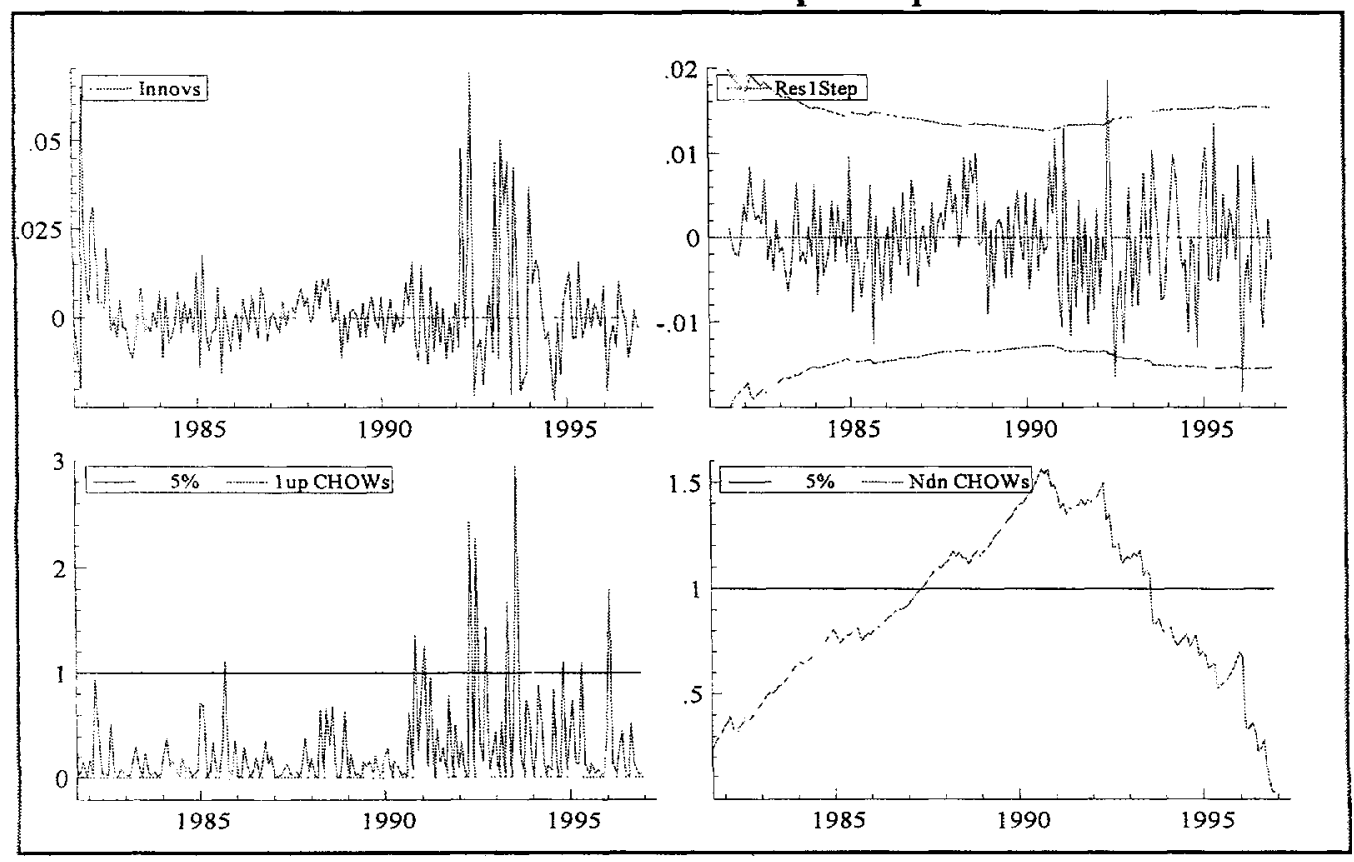


TABLE 18 - MALAYSIA: Single Equation for Prices (Modeling $\left.\Delta^{2} p\right)^{*}$

\begin{tabular}{|c|c|c|c|c|}
\hline Variable & Coefficient & Std. Error & t-value & Hansen Instability \\
\hline Constant & 0.009 & 0.027 & 0.337 & 0.27 \\
\hline$\Delta^{2} p_{t-1}$ & -0.164 & 0.063 & -2.596 & 0.04 \\
\hline$\Delta^{2} m_{t-1}$ & 0.008 & 0.011 & 0.762 & 0.45 \\
\hline$\Delta y_{t}$ & -0.007 & 0.005 & -1.378 & 0.04 \\
\hline$\Delta I_{i}^{O}$ & 0.000 & 0.001 & 0.256 & 0.07 \\
\hline$\Delta I_{t-2}^{A}$ & -0.001 & 0.001 & -2.679 & 0.06 \\
\hline$\Delta e_{t}$ & 0.050 & 0.022 & 2.283 & 0.21 \\
\hline$\Delta e_{t-3}$ & -0.058 & 0.021 & -2.841 & 0.3 \\
\hline$\Delta e_{t-5}$ & 0.065 & 0.020 & 3.302 & 0.31 \\
\hline$\Delta p_{t-1}^{*}$ & 0.399 & 0.108 & 3.704 & 0.16 \\
\hline MysECMrM2 $2_{t-1}$ & -0.002 & 0.001 & -1.213 & 0.23 \\
\hline MysECMytrend ${ }_{t-1}$ & 0.004 & 0.005 & 0.832 & 0.27 \\
\hline MysECMIalt $_{t-1}$ & 0.000 & 0.001 & 0.250 & 0.3 \\
\hline MysECMIown $_{t-1}$ & -0.000 & 0.001 & -0.004 & 0.31 \\
\hline $\mathrm{MysECMrPPP}_{\mathrm{t}-1}$ & 0.001 & 0.001 & 0.559 & 0.09 \\
\hline
\end{tabular}

Sample:1980:8-1996:12

$\mathrm{R}^{2}=0.703996 \quad \mathrm{~F}(26,170)=15.551[0.0000]$

\begin{tabular}{|c|c|}
\hline AR $1-7 F(7,163$ & $=0.80692[0.5827]$ \\
\hline $\mathrm{ARCH} 7 \mathrm{~F}(7,156)$ & $1.0472[0.4006]$ \\
\hline Normality $\mathrm{Chi}^{2}(2)$ & $4.9951[0.0823]$ \\
\hline HETERO $\quad F(40,129)$ & $1.4135[0.0761]$ \\
\hline
\end{tabular}

Hansen Instability Test Results: Variance: 0.354895 Joint (variance \& coefficients): 5.31541 F-CRISIS $(48,122)=0.7358[0.8858]$

FIGURE 18 - MALAYSIA: Recursive estimation for price equation

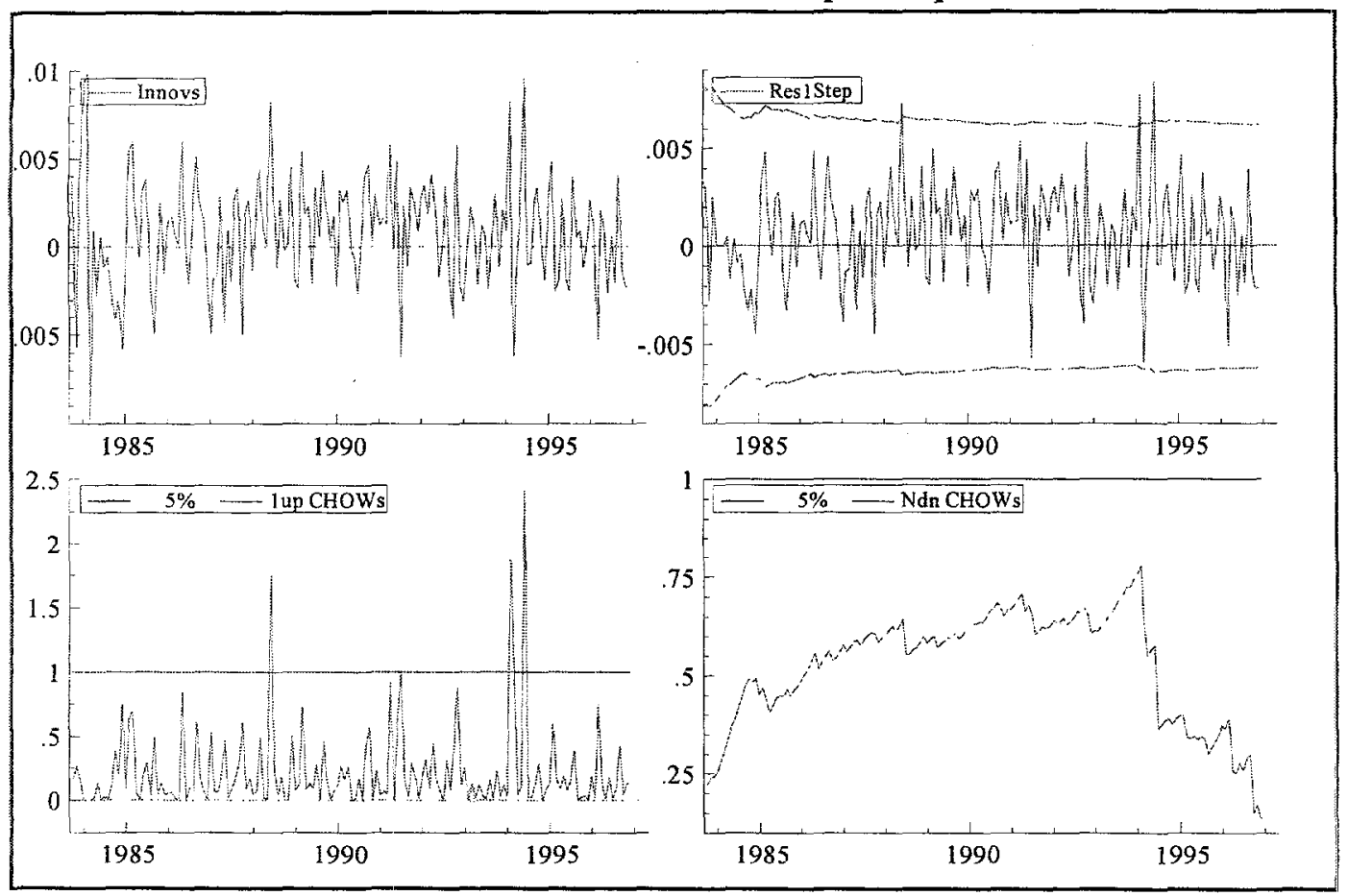

* For a list of and explanation for the dummies used in estimation, see Table A.5 
TABLE 19 - URUGUAY: Single Equation for Prices (Modeling $\Delta^{2} p$ ) *

\begin{tabular}{|c|c|c|c|c|}
\hline Variable & Coefficient & Std. Error & t-value & Hansen Instability \\
\hline Constant & 0.019 & 0.104 & 0.188 & 0.17 \\
\hline$\Delta^{2} p_{t-1}$ & -0.306 & 0.123 & -2.491 & 0.16 \\
\hline$\Delta^{2} p_{t-2}$ & -0.385 & 0.098 & -3.920 & 0.05 \\
\hline$\Delta^{2} p_{t-3}$ & -0.214 & 0.087 & -2.473 & 0.04 \\
\hline$\Delta^{2} p_{t-4}$ & -0.190 & 0.069 & -2.760 & 0.32 \\
\hline$\Delta^{2} p_{t-5}$ & -0.238 & 0.050 & -4.733 & 0.03 \\
\hline$\Delta^{2} p_{t-7}$ & -0.168 & 0.039 & -4.301 & 0.18 \\
\hline$\Delta^{2} m_{t-5}$ & 0.093 & 0.022 & 4.175 & 0.12 \\
\hline$\Delta^{2} m_{t-6}$ & 0.090 & 0.028 & 3.264 & 0.19 \\
\hline$\Delta^{2} m_{1-7}$ & 0.105 & 0.028 & 3.691 & 0.09 \\
\hline$\Delta^{2} m_{i-8}$ & 0.080 & 0.025 & 3.185 & 0.07 \\
\hline$\Delta^{2} m_{t-9}$ & 0.050 & 0.020 & 2.446 & 0.07 \\
\hline$\Delta y_{i-4}$ & 0.039 & 0.017 & 2.365 & $0.69 *$ \\
\hline$\Delta I_{t}^{O}$ & 0.001 & 0.000 & 2.877 & 0.05 \\
\hline$\Delta l_{t-3}^{O}$ & -0.001 & 0.000 & -3.516 & 0.03 \\
\hline$\Delta I_{t-8}^{O}$ & -0.001 & 0.000 & -2.880 & 0.13 \\
\hline$\Delta u_{t-1}$ & -0.051 & 0.012 & -4.158 & 0.1 \\
\hline$\Delta u_{t-2}$ & 0.053 & 0.013 & 4.125 & 0.1 \\
\hline$\Delta u_{t-3}$ & -0.066 & 0.015 & -4.430 & 0.08 \\
\hline$\Delta u_{t-6}$ & -0.039 & 0.014 & -2.775 & 0.15 \\
\hline$\Delta u_{1-7}$ & 0.031 & 0.012 & 2.568 & 0.09 \\
\hline$\Delta^{2} w_{t}$ & 0.151 & 0.022 & 6.965 & 0.23 \\
\hline$\Delta^{2} w_{t-1}$ & 0.110 & 0.020 & 5.578 & $0.56^{*}$ \\
\hline$\Delta e_{t}$ & -0.107 & 0.048 & -2.240 & 0.04 \\
\hline$\Delta e_{t-1}$ & 0.118 & 0.018 & 6.663 & 0.04 \\
\hline$\Delta p_{t}^{*}$ & 1.053 & 0.409 & 2.575 & 0.11 \\
\hline$\Delta I_{t-1}^{*}$ & 0.008 & 0.002 & 3.726 & 0.1 \\
\hline$\Delta I_{t-9}^{*}$ & 0.005 & 0.002 & 2.557 & 0.2 \\
\hline uruECMrPPP ${ }_{t-1}$ & -0.003 & 0.004 & -0.774 & 0.1 \\
\hline uruECMuip $p_{t-1}$ & 0.000 & 0.000 & 3.332 & 0.12 \\
\hline uruECMrM2 $2_{t-1}$ & 0.001 & 0.008 & 0.105 & 0.17 \\
\hline uruECMrwage $_{t-1}$ & 0.026 & 0.017 & 1.476 & 0.17 \\
\hline
\end{tabular}

Sample: 1982:9-1997:12

$\mathrm{R}^{2}=0.875851$

$F(39,144)=26.049[0.0000]$

AR 1- $7 F(7,137)=0.95472[0.4670]$

$\mathrm{ARCH} 7 \mathrm{~F}(7,130) \quad=0.75209[0.6284]$

Normality $\mathrm{Chi}^{2}(2) \quad=0.24055[0.8867]$

HETERO $\mathrm{F}(70,73) \quad=1.1522[0.2748]$

Hansen Instability Test Results: Variance: 0.210029 Joint (variance \& coefficients): 5.56761

F-CRISIS $(38,106)=2.1422[0.0012] * *$

\footnotetext{
*For a list of and explanation for the dummies used in estimation, see Table A.5.

*** Denotes significance at $5 \%$ and $1 \%$, respectively.
} 
FIGURE 19 - URUGUAY: Recursive estimation for price equation

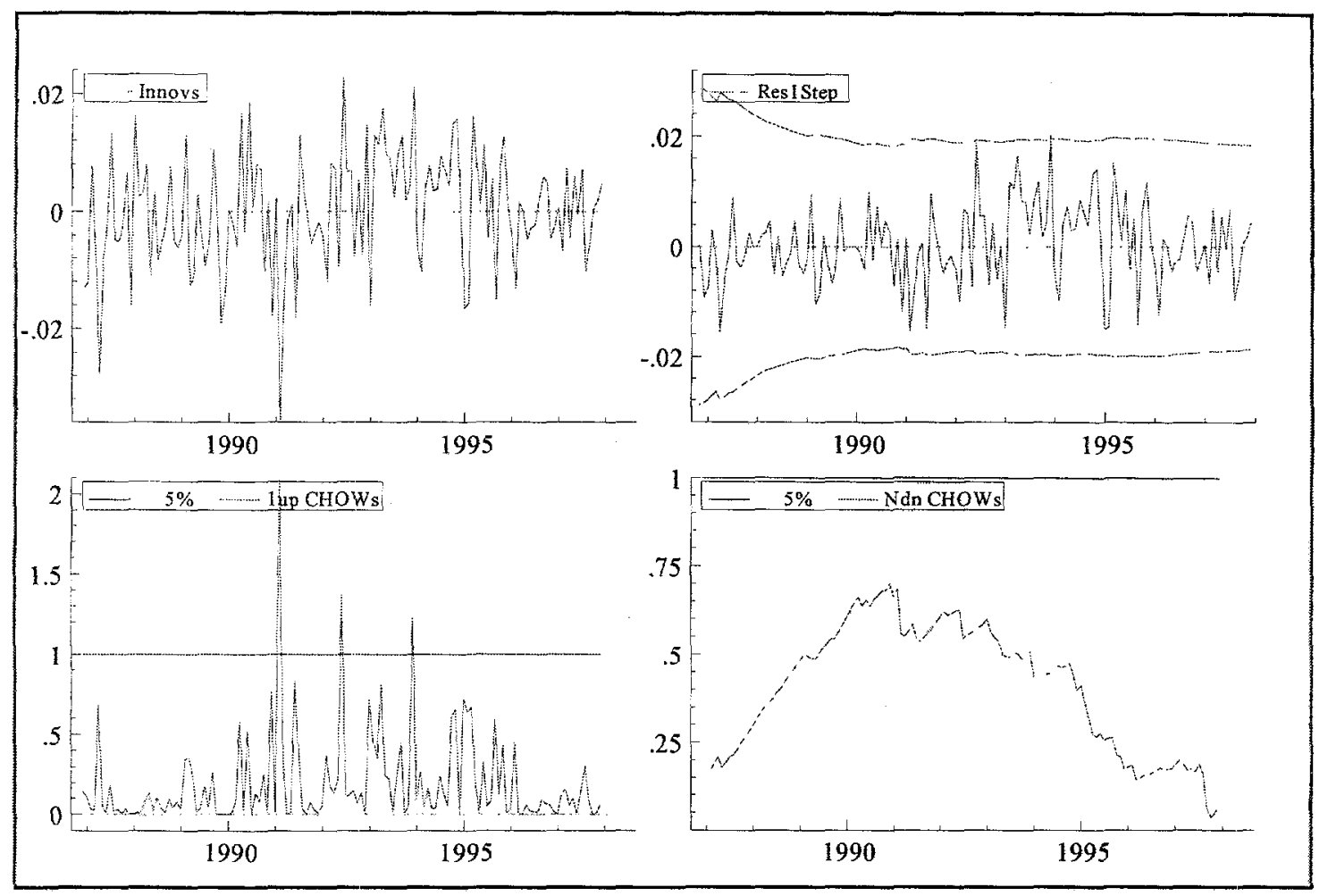


TABLE 20 - CHILE: Price equation with crisis interactions ${ }^{\dagger}$

\begin{tabular}{|c|c|c|c|c|c|}
\hline Variable & Coefficient & Std.Error & Interacted Variable & Coefficient & Std.Error \\
\hline Constant & -0.123 & 0.099 & & & \\
\hline$\Delta^{2} p_{t-2}$ & -0.105 & 0.095 & $\Delta^{2} p_{t-2}{ }^{*}$ crisis dummy & -0.062 & 0.111 \\
\hline$\Delta^{2} m_{t-2}$ & $0.036 *$ & 0.017 & $\Delta^{2} m_{t-2} *$ crisis dummy & -0.017 & 0.025 \\
\hline$\Delta y_{t}$ & -0.011 & 0.014 & $\Delta y_{i}^{*}$ crisis dummy & -0.016 & 0.013 \\
\hline$\Delta I_{t-5}^{O}$ & -0.0001 & 0.0001 & $\Delta I_{t-5}^{O}{ }^{*}$ crisis dummy & -0.0001 & 0.0001 \\
\hline$\Delta I_{t-6}^{O}$ & $-0.0002 *$ & 0.0001 & $\Delta I_{t-6}^{O}{ }^{*}$ crisis dummy & 0.0001 & 0.0001 \\
\hline$\Delta e_{i}$ & 0.09 & 0.057 & $\Delta e_{1}{ }^{*}$ crisis dummy & -0.026 & 0.068 \\
\hline$\Delta p_{i}^{*}$ & $0.978^{* *}$ & 0.316 & $\Delta p_{t}^{*}{ }^{*}$ crisis dummy & -0.167 & 0.413 \\
\hline$\Delta^{2} w_{t}$ & -0.032 & 0.018 & $\Delta^{2} w_{t} *$ crisis dummy & $0.0 \overline{3}$ & 0.032 \\
\hline$\Delta u_{f}$ & -0.019 & 0.012 & $\Delta u_{t}{ }^{*}$ crisis dummy & 0.002 & 0.015 \\
\hline$\Delta s p_{t}$ & -0.002 & 0.011 & $\Delta s p_{t}{ }^{*}$ crisis dummy & 0.009 & 0.017 \\
\hline chiECMrM2 $2_{t-1}$ & 0.001 & 0.008 & ChiECMrM2 $2_{t-1}{ }^{*}$ crisis dummy & 0.004 & 0.007 \\
\hline chiECMytrend $d_{t-1}$ & 0.015 & 0.014 & ChiECMytrend $d_{t-1}{ }^{*}$ crisis dummy & -0.016 & 0.009 \\
\hline chiECMIown $n_{t-1}$ & 0.00002 & 0.0001 & ChiECMlown $_{t-1}{ }^{*}$ crisis dummy & 0.0001 & 0.0001 \\
\hline chiECMrPPP ${ }_{t-1}$ & $-0.009 *$ & 0.004 & ChiECMrPPP $_{t-1}{ }^{*}$ crisis dummy & -0.005 & 0.003 \\
\hline chiECMrwage $e_{t-1}$ & -0.007 & 0.014 & ChiECMrwage $e_{1-1}{ }^{*}$ crisis dummy & 0.019 & 0.02 \\
\hline
\end{tabular}

tCrisis dummy equals one for the period 1981(1) - 1987(12) and it is zero otherwise.

TABLE 21 - COLOMBIA: Price equation with crisis interactions ${ }^{\dagger}$

\begin{tabular}{|c|c|c|c|c|c|}
\hline Variable & Coefficient & Std.Error & Interacted Variable & Coefficient & Std.Error \\
\hline Constant & $-0.303^{*}$ & 0.119 & & & \\
\hline$\Delta p_{i-1}$ & $0.388^{* *}$ & 0.099 & $\Delta p_{t-1}{ }^{*}$ crisis dummy & -0.023 & 0.121 \\
\hline$\Delta p_{t-11}$ & 0.143 & 0.109 & $\Delta p_{t-11}{ }^{*}$ crisis dummy & 0.092 & 0.119 \\
\hline$\Delta p_{t-12}$ & $-0.258^{*}$ & 0.11 & $\Delta p_{t-12}{ }^{*}$ crisis dummy & -0.029 & 0.118 \\
\hline$\Delta m_{t-1}$ & 0.004 & 0.039 & $\Delta m_{t-1}{ }^{*}$ crisis dummy & -0.116 & 0.088 \\
\hline$\Delta y_{i}$ & -0.013 & 0.013 & $\Delta y_{t}{ }^{*}$ crisis dummy & -0.004 & 0.017 \\
\hline$\Delta I_{t}^{O}$ & 0.001 & 0.0004 & $\Delta I_{t}^{O *}$ crisis dummy & -0.001 & 0.001 \\
\hline$\Delta I_{t}^{*}$ & -0.002 & 0.003 & $\Delta I_{t}^{*}{ }^{*}$ crisis dummy & -0.000 & 0.003 \\
\hline$\Delta I_{t-7}^{*}$ & -0.003 & 0.002 & $\Delta I_{t-7}^{*}{ }^{*}$ crisis dummy & -0.0004 & 0.002 \\
\hline$\Delta p_{t-2}^{*}$ & -0.304 & 0.383 & $\Delta p_{t-2}^{*}{ }^{*}$ crisis dummy & 0.967 & 0.519 \\
\hline$\Delta p_{t-3}^{*}$ & 0.588 & 0.399 & $\Delta p_{i-3}^{*}{ }^{*}$ crisis dummy & 0.138 & 0.571 \\
\hline$\Delta p_{t-4}^{*}$ & -0.341 & 0.37 & $\Delta p_{t-4}^{*} *$ crisis dummy & 0.107 & 0.483 \\
\hline$\Delta e_{i}$ & 0.036 & 0.031 & $\Delta e_{t}{ }^{*}$ crisis dummy & -0.043 & 0.119 \\
\hline$\Delta w_{i}$ & $0.117^{*}$ & 0.049 & $\Delta w_{t} *$ crisis dummy & -0.081 & 0.111 \\
\hline$\Delta u_{t}$ & -0.009 & 0.012 & $\Delta u_{t}{ }^{*}$ crisis dummy & 0.031 & 0.022 \\
\hline$\Delta s p_{t}$ & 0.013 & 0.007 & $\Delta s p_{t}{ }^{*}$ crisis dummy & -0.013 & 0.019 \\
\hline ColECMnwage $_{t-1}$ & 0.042 & 0.03 & ColECMnwage $_{t-1} *$ crisis dummy & -0.005 & -0.095 \\
\hline ColECMnM2 $_{t-1}$ & $0.026^{*}$ & 0.013 & ColECMnM2 ${ }_{\mathrm{t}-1}{ }^{*}$ crisis dummy & 0.006 & 0.010 \\
\hline ColECMIown $\mathrm{t}_{\mathrm{t}-1}$ & 0.0001 & 0.001 & ColECMIown $\mathrm{t}_{-1}{ }^{*}$ crisis dummy & 0.001 & 0.001 \\
\hline ColECMnPPP $_{\mathrm{t}-1}$ & $-0.025 * *$ & 0.009 & ColECMnPPP ${ }_{t-1}{ }^{*}$ crisis dummy & 0.010 & 0.011 \\
\hline ColECMIfor $_{t-1}$ & -0.000 & 0.001 & ColECMIfor $_{t-1}{ }^{*}$ crisis dummy & 0.001 & 0.001 \\
\hline
\end{tabular}

tCrisis dummy equals one for the period $1982(1)-1987(12)$ and it is zero otherwise. 
TABLE 22 - DENMARK: Price equation with crisis interactions

\begin{tabular}{|c|c|c|c|c|c|}
\hline Variable & Coefficient & Std.Error & Interacted Variable & Coefficient & Std.Error \\
\hline Constant & 0.108 & 0.056 & & & \\
\hline$\Delta^{2} p_{t-1}$ & $0.233^{* *}$ & $0.0 \overline{73}$ & $\Delta^{2} p_{t-1}{ }^{*}$ crisis dummy & -0.003 & 0.132 \\
\hline$\Delta^{2} m_{t-12}$ & 0.006 & 0.011 & $\Delta^{2} m_{t-12}{ }^{*}$ crisis dummy & 0.019 & 0.011 \\
\hline$\Delta y_{1-5}$ & 0.011 & 0.009 & $\Delta y_{t-5} *$ crisis dummy & 0.015 & 0.019 \\
\hline$\Delta I_{t-1}^{O}$ & $0.003 * *$ & 0.001 & $\Delta I_{t-1}^{O} *$ crisis dummy & -0.001 & 0.002 \\
\hline$\Delta I_{t}^{A}$ & -0.001 & 0.001 & $\Delta V_{t}^{A}{ }^{*}$ crisis dummy & 0.001 & $\overline{0.002}$ \\
\hline$\Delta e_{1}$ & 0.014 & 0.039 & $\Delta e_{t}^{*}$ crisis dummy & 0.033 & $\overline{0.124}$ \\
\hline$\Delta p_{i}^{*}$ & $0.345 * *$ & 0.11 & $\Delta p_{i}^{*}{ }^{*}$ crisis dummy & 0.060 & 0.173 \\
\hline$\Delta V_{t}^{*}$ & $0.002^{*}$ & 0.001 & $\Delta I_{t}^{*}{ }^{*}$ crisis dummy & -0.004 & 0.002 \\
\hline$\Delta u_{t-5}$ & $0.02^{* *}$ & 0.007 & $\Delta u_{t-5}{ }^{*}$ crisis dummy & -0.0002 & 0.009 \\
\hline$\Delta u_{t-6}$ & $0.022 * *$ & 0.007 & $\Delta u_{t-6}{ }^{*}$ crisis dummy & -0.008 & 0.009 \\
\hline$\Delta i_{-12}$ & $0.027^{* *}$ & 0.007 & $\Delta u_{t-12}{ }^{*}$ crisis dummy & -0.006 & 0.010 \\
\hline$\Delta^{2} w_{i}$ & $0.048^{*}$ & 0.022 & $\Delta^{2} w_{i}^{*}$ crisis dummy & 0.004 & 0.022 \\
\hline$\overline{\text { DenECMrM2 } 2_{t-1}}$ & $-0.009 * *$ & 0.003 & denECMrM $2_{1-1}{ }^{*}$ crisis dummy & 0.003 & 0.002 \\
\hline DenECMinfi $_{t-1}$ & $-0.005 *$ & 0.002 & denECMinfl $l_{t-1}{ }^{*}$ crisis dummy & -0.005 & $\overline{0.009}$ \\
\hline DenECMrwage $_{t-1}$ & -0.003 & 0.002 & denECMrwage $_{t-1}{ }^{*}$ crisis dummy & 0.001 & 0.005 \\
\hline DenECMrPPP $_{t-1}$ & $-0.041 * *$ & 0.011 & denECMrPPP ${ }_{1-1}{ }^{*}$ crisis dummy & 0.042 & 0.031 \\
\hline DenECMuip $_{t-1}$ & $0.0002 *$ & 0.0001 & denECMuip $p_{t-1}{ }^{*}$ crisis dummy & 0.001 & 0.0005 \\
\hline
\end{tabular}

${ }^{t}$ Crisis dummy equals one for the period $1987(1)-1992(12)$ and it is zero otherwise.

TABLE 23 - JAPAN: Price equation with crisis interactions ${ }^{\dagger}$

\begin{tabular}{|c|c|c|c|c|c|}
\hline Variable & Coefficient & Std.Error & Interacted Variable & Coefficient & Std.Error \\
\hline Constant & -0.005 & 0.012 & & & \\
\hline$\Delta^{2} p_{l-10}$ & $-0.100 *$ & 0.051 & $\Delta^{2} p_{t-10}{ }^{*}$ crisis dummy & $0.265 * *$ & 0.089 \\
\hline$\Delta^{2} p_{t-11}$ & $-0.171 * *$ & 0.052 & $\Delta^{2} p_{t-11}{ }^{*}$ crisis dummy & $0.261 * *$ & 0.091 \\
\hline$\overline{\Delta^{2} m_{t-1}}$ & $0.079 * *$ & 0.024 & $\Delta^{2} m_{s-1}{ }^{*}$ crisis dummy & $-0.089 * *$ & $\overline{0.033}$ \\
\hline$\Delta y_{t}$ & 0.018 & 0.019 & $\Delta y_{t}{ }^{*}$ crisis dummy & 0.013 & 0.026 \\
\hline$\Delta I_{i-6}^{A}$ & $0.002 *$ & 0.001 & $\Delta I_{t-6}^{A}{ }^{*}$ crisis dummy & 0.001 & 0.002 \\
\hline$\Delta I_{1-2}^{O}$ & $-0.001^{*}$ & 0.001 & $\Delta I_{t-2}^{O}{ }^{*}$ crisis dummy & -0.003 & 0.002 \\
\hline$\Delta T_{t-11}^{O}$ & $-0.001^{*}$ & 0.001 & $\Delta I_{t-11}^{O}{ }^{*}$ crisis dummy & -0.0001 & 0.002 \\
\hline$\Delta I_{i-1}^{b}$ & $-0.002^{*}$ & 0.001 & $\Delta I_{t-1}^{b}{ }^{*}$ crisis dummy & 0.002 & 0.001 \\
\hline$\Delta_{t-5}^{b}$ & $-0.002 * *$ & 0.001 & $\Delta V_{t-5}^{b}{ }^{*}$ crisis dummy & 0.002 & 0.001 \\
\hline$\Delta e_{i-2}$ & $0.024^{* *}$ & 0.009 & $\Delta e_{t-2}{ }^{*}$ crisis dummy & -0.019 & 0.016 \\
\hline$\Delta e_{t-5}$ & $0.022 *$ & 0.009 & $\Delta e_{t-5}{ }^{*}$ crisis dummy & -0.019 & 0.015 \\
\hline$\Delta e_{t-7}$ & 0.016 & 0.009 & $\Delta e_{t-7}{ }^{*}$ crisis dummy & -0.009 & 0.015 \\
\hline$\Delta p_{-2}^{*}$ & $0.516^{* *}$ & 0.109 & $\Delta p_{-2}^{*}{ }^{*}$ crisis dummy & -0.071 & 0.223 \\
\hline$\Delta p_{i-6}^{*}$ & $-0.279^{*}$ & 0.107 & $\Delta p_{t-6}^{*}{ }^{*}$ crisis dummy & 0.174 & 0.219 \\
\hline$\Delta p_{-9}^{*}$ & $0.305 * *$ & 0.094 & $\Delta q_{-9}^{*}{ }^{*}$ crisis dummy & -0.122 & 0.211 \\
\hline$\Delta I_{t}^{*}$ & -0.0001 & 0.001 & $\Delta I_{t}^{*}{ }^{*}$ crisis dummy & 0.001 & 0.002 \\
\hline$\Delta^{2} w_{t}$ & 0.008 & 0.005 & $\Delta^{2} w_{t}{ }^{*}$ crisis dummy & 0.0002 & $\overline{0.001}$ \\
\hline$\Delta u_{l}$ & -0.001 & 0.007 & $\Delta u_{t}{ }^{*}$ crisis dummy & -0.011 & 0.012 \\
\hline$\Delta s p_{1}$ & -0.011 & $0.00 \overline{9}$ & $\Delta s p_{t}{ }^{*}$ crisis dummy & 0.011 & $\overline{0.011}$ \\
\hline JapECMrm2 $2_{t-1}$ & -0.003 & 0.002 & japECMrm $2_{t-1}{ }^{*}$ crisis dummy & 0.001 & 0.002 \\
\hline JapECMrPPQ & $-0.002^{*}$ & $0 . \overline{001}$ & japECMrPPP ${ }_{t-1}{ }^{*}$ crisis dummy & 0.001 & 0.001 \\
\hline JapECMuip $_{\mathrm{i}-1}$ & $0.001^{* *}$ & 0.0002 & japECMuip ${ }_{t-1}{ }^{*}$ crisis dummy & 0.0001 & 0.0004 \\
\hline JapECMrwage $_{t-1}$ & 0.006 & 0.003 & japECMrwage ${ }_{1-1}{ }^{*}$ crisis dummy & -0.001 & 0.001 \\
\hline
\end{tabular}

${ }^{\dagger}$ Crisis dummy equals one for the period $1990(1)-1997(12)$ and it is zero otherwise. 
TABLE 24 - KENYA: Price equation with crisis interactions ${ }^{\dagger}$

\begin{tabular}{|c|c|c|c|c|c|}
\hline Variable & Coefficient & Std.Error & Interacted Variable & Coefficient & Std.Error \\
\hline Constant & -0.496 & 0.694 & & & \\
\hline$\Delta p_{i-3}$ & 0.039 & 0.061 & $\Delta p_{t-3}{ }^{*}$ crisis dummy & 0.081 & 0.082 \\
\hline$\Delta p_{t-4}$ & 0.012 & 0.063 & $\Delta p_{t-4}{ }^{*}$ crisis dummy & -0.114 & 0.083 \\
\hline$\Delta p_{i-8}$ & $0.144^{*}$ & 0.059 & $\Delta p_{t-8}{ }^{*}$ crisis dummy & -0.128 & 0.094 \\
\hline$\Delta m_{t-3}$ & 0.036 & 0.025 & $\Delta m_{l-3}{ }^{*}$ crisis dummy & -0.022 & 0.055 \\
\hline$\Delta m_{f-4}$ & 0.049 & 0.026 & $\Delta m_{t-4}{ }^{*}$ crisis dummy & 0.073 & 0.055 \\
\hline$\Delta y_{t}$ & 0.165 & 0.481 & $\Delta y_{t} *$ crisis dummy & $-5.081 * *$ & 1.791 \\
\hline$\Delta l_{t-4}^{A}$ & 0.001 & 0.001 & $\Delta U_{t-4}^{A} *$ crisis dummy & -0.001 & 0.001 \\
\hline$\Delta I_{i-5}^{A}$ & 0.0004 & 0.001 & $\Delta I_{t-5}^{A} *$ crisis dummy & 0.001 & 0.001 \\
\hline$\Delta I_{t-1}^{o}$ & 0.001 & 0.001 & $\Delta I_{1-1}^{0} *^{*}$ crisis dummy & 0.002 & 0.002 \\
\hline$\Delta I_{t-2}^{O}$ & -0.002 & 0.002 & $\Delta I_{t-2}^{0} *$ crisis dummy & -0.002 & 0.002 \\
\hline$\Delta I_{i-6}^{o}$ & $0.003^{*}$ & 0.001 & $\Delta V_{t-6}^{O}{ }^{*}$ crisis dummy & 0.002 & 0.002 \\
\hline$\Delta I_{i}^{*}$ & 0.001 & 0.001 & $\Delta_{i}^{*}{ }^{*}$ crisis dummy & $0.031 * *$ & 0.012 \\
\hline$\Delta e_{t}$ & 0.025 & 0.033 & $\Delta e_{t}{ }^{*}$ crisis dummy & 0.047 & 0.044 \\
\hline$\Delta p_{t-2}^{*}$ & $0.633^{*}$ & 0.254 & $\Delta p_{t-2}^{*}{ }^{*}$ crisis dummy & 0.379 & 1.098 \\
\hline kenECMnM2 $2_{t-1}$ & 0.005 & 0.009 & kenECMnM2 $2_{t-1}{ }^{*}$ crisis dummy & -0.018 & 0.019 \\
\hline kenECMgdp $_{t-1}$ & 0.020 & 0.029 & kenECMgdp $_{t-1}{ }^{*}$ crisis dummy & -0.012 & 0.007 \\
\hline kenECMispr $_{t-1}$ & 0.003 & 0.002 & kenECMispr $_{\mathrm{t}-1}{ }^{*}$ crisis dummy & -0.002 & 0.001 \\
\hline kenECMnPPP :- & -0.002 & 0.003 & kenECMnPPP $_{t-1}{ }^{*}$ crisis dummy & $-0.054 *$ & 0.022 \\
\hline kenECMidiff $_{\mathrm{t}-1}$ & -0.006 & 0.012 & kenECMidiff $_{t-1}{ }^{*}$ crisis dummy & $-0.214^{*}$ & 0.087 \\
\hline
\end{tabular}

${ }^{t}$ Crisis dummy equals one for the period 1992(1) - 1995(12) and it is zero otherwise

TABLE 25-MALAYSIA: Price equation with crisis interactions ${ }^{t}$

\begin{tabular}{|c|c|c|c|c|c|}
\hline Variable & Coefficient & Std. Error & Interacted Variable & Coefficient & Std. Error \\
\hline Constant & 0.016 & 0.028 & & & \\
\hline$\Delta^{2} p_{t-1}$ & $-0.153 *$ & 0.068 & $\Delta^{2} p_{t-1}{ }^{*}$ crisis dummy & 0.139 & 0.168 \\
\hline$\Delta^{2} m_{i-1}$ & 0.002 & 0.011 & $\Delta^{2} m_{t-1}{ }^{*}$ crisis dummy & 0.038 & 0.033 \\
\hline$\Delta y_{t}$ & -0.009 & 0.006 & $\Delta y_{t} *^{*}$ crisis dummy & -0.002 & 0.011 \\
\hline$\Delta I_{i}^{O}$ & -0.001 & 0.001 & $\Delta I_{t}^{O}{ }^{*}$ crisis dummy & 0.002 & 0.001 \\
\hline$\Delta I_{t-2}^{A}$ & $-0.002 * *$ & 0.001 & $\Delta I_{t-2}^{A} *^{*}$ crisis dummy & 0.001 & 0.001 \\
\hline$\Delta e_{\text {, }}$ & $0.061^{*}$ & 0.025 & $\Delta e_{t}^{*}$ crisis dummy & -0.029 & 0.053 \\
\hline$\Delta e_{1-3}$ & $-0.052 *$ & 0.023 & $\Delta e_{t-3} *$ crisis dummy & -0.007 & 0.056 \\
\hline$\Delta e_{t-5}$ & 0.038 & 0.022 & $\Delta e_{t-5}{ }^{*}$ crisis dummy & $0.127 *$ & 0.053 \\
\hline$\Delta p_{t-1}^{*}$ & $0.399 * *$ & 0.124 & $\Delta p_{t-1}^{*}{ }^{*}$ crisis dummy & -0.149 & 0.277 \\
\hline mysECMrM2 ${ }_{t-1}$ & -0.001 & 0.001 & mysECMrM2 $\mathrm{t}_{\mathrm{t}-1}{ }^{*}$ crisis dummy & 0.001 & 0.003 \\
\hline mysECMytrend $t_{-1}$ & 0.001 & 0.005 & mysECMytrend $_{t-1}{ }^{*}$ crisis dummy & -0.002 & 0.013 \\
\hline mysECMIalt $t_{t-1}$ & 0.001 & 0.001 & mysECMIalt $_{\mathrm{t}-1}{ }^{*}$ crisis dummy & -0.002 & 0.002 \\
\hline mysECMIown $_{\mathrm{t}-1}$ & -0.001 & 0.001 & mysECMIown $_{\mathrm{t}-1}{ }^{*}$ crisis dummy & 0.002 & 0.002 \\
\hline mysECMrPPP $_{t-1}$ & 0.001 & 0.001 & mysECMrPPP $_{t-1}{ }^{*}$ crisis dummy & 0.001 & 0.003 \\
\hline
\end{tabular}

${ }^{t}$ Crisis dummy equals one for the period 1985(1) - 1988(12) and it is zero otherwise

\footnotetext{
* Denotes significance at the $5 \%$ level.

** Denotes significance at the $1 \%$ level.
} 
TABLE 26-URUGUAY: Price equation with crisis interactions ${ }^{\dagger}$

\begin{tabular}{|c|c|c|c|c|c|}
\hline Variable & Coefficient & Std. Error & Interacted Variable & Coefficient & Std. Error \\
\hline Constant & -0.13 & 0.119 & & & \\
\hline$\Delta^{2} p_{t-1}$ & -0.213 & 0.185 & $\Delta^{2} p_{t-1}{ }^{*}$ crisis dummy & $-0.725 *$ & 0.327 \\
\hline$\Delta^{2} p_{t-2}$ & -0.246 & 0.167 & $\Delta^{2} p_{t-2}{ }^{*}$ crisis dummy & $-0.641 *$ & 0.271 \\
\hline$\Delta^{2} p_{t-3}$ & -0.056 & 0.145 & $\Delta^{2} p_{t-3}{ }^{*}$ crisis dummy & $-0.619 *$ & 0.245 \\
\hline$\Delta^{2} p_{i-4}$ & 0.038 & 0.115 & $\Delta^{2} p_{t-4}{ }^{*}$ crisis dummy & $-0.685^{* *}$ & 0.197 \\
\hline$\Delta^{2} p_{t-s}$ & -0.044 & 0.071 & $\Delta^{2} p_{t-5}{ }^{*}$ crisis dummy & $-0.521 * *$ & 0.155 \\
\hline$\overline{\Delta^{2} p_{t-7}}$ & $-0.159 * *$ & .0546 & $\Delta^{2} p_{t-7}{ }^{*}$ crisis dummy & -0.067 & 0.102 \\
\hline$\Delta^{2} m_{t-5}$ & $0.061^{*}$ & 0.029 & $\Delta^{2} m_{t-5}{ }^{*}$ crisis dummy & $0.155^{*}$ & 0.062 \\
\hline$\Delta^{2} m_{t-6}$ & $0.088 *$ & 0.036 & $\Delta^{2} m_{t-6}{ }^{*}$ crisis dummy & $0.169^{*}$ & 0.075 \\
\hline$\Delta^{2} m_{t-7}$ & 0.065 & 0.036 & $\Delta^{2} m_{t-7}{ }^{*}$ crisis dummy & $0.227^{* *}$ & 0.072 \\
\hline$\Delta^{2} m_{t-8}$ & 0.023 & 0.036 & $\Delta^{2} m_{t-8}{ }^{*}$ crisis dummy & $0.137^{*}$ & 0.06 \\
\hline$\Delta^{2} m_{t-9}$ & 0.021 & 0.028 & $\Delta^{2} m_{t-9}{ }^{*}$ crisis dummy & 0.053 & 0.05 \\
\hline$\Delta y_{t-4}$ & 0.025 & 0.018 & $\Delta y_{t-4}{ }^{*}$ crisis dummy & 0.049 & 0.059 \\
\hline$\Delta I_{i}^{O}$ & $0.001^{*}$ & 0.0003 & $\Delta J_{t}^{O}{ }^{*}$ crisis dummy & 0.001 & 0.001 \\
\hline$\Delta I_{t-3}^{O}$ & $-0.001 * *$ & 0.0003 & $\Delta I_{t-3}^{O} *$ crisis dummy & 0.0004 & 0.001 \\
\hline$\Delta V_{t-8}^{O}$ & -0.0002 & 0.0003 & $\Delta I_{t-8}^{O}{ }^{*}$ crisis dummy & -0.001 & 0.001 \\
\hline$\Delta u_{t-1}$ & $-0.04 * *$ & 0.013 & $\Delta u_{t-1}{ }^{*}$ crisis dummy & $-0.145 *$ & 0.063 \\
\hline$\Delta u_{t-2}$ & $0.052 * *$ & 0.014 & $\Delta u_{i-2}{ }^{*}$ crisis dummy & 0.114 & 0.065 \\
\hline$\Delta t_{t-3}$ & $0.041 *$ & 0.017 & $\Delta u_{t-3}{ }^{*}$ crisis dummy & -0.007 & 0.064 \\
\hline$\Delta u_{t-6}$ & -0.017 & 0.015 & $\Delta u_{t-6} *$ crisis dummy & $-0.125 *$ & 0.052 \\
\hline$\Delta u_{t-7}$ & $0.033 * *$ & 0.012 & $\Delta u_{t-7} *$ crisis dummy & 0.109 & 0.064 \\
\hline$\overline{\Delta^{2} w_{t}}$ & $0.131 * *$ & 0.032 & $\Delta^{2} w_{t}{ }^{*}$ crisis dummy & 0.049 & 0.055 \\
\hline$\Delta^{2} w_{l-1}$ & $0.069 *$ & 0.027 & $\Delta^{2} w_{t-1}{ }^{*}$ crisis dummy & $0.131^{*}$ & 0.051 \\
\hline$\Delta e_{t}$ & -0.184 & 0.094 & $\Delta e_{t}{ }^{*}$ crisis dummy & 0.205 & 0.127 \\
\hline$\Delta e_{t-1}$ & 0.002 & 0.099 & $\Delta e_{t-1}{ }^{*}$ crisis dummy & 0.090 & 0.108 \\
\hline$\Delta p_{i}^{*}$ & $1.555^{* *}$ & 0.449 & $\Delta p_{t}^{* *}$ crisis dummy & -0.997 & 1.857 \\
\hline$\Delta I_{t-1}^{*}$ & 0.006 & 0.003 & $\Delta I_{t-1}^{*}{ }^{*}$ crisis dummy & -0.0001 & 0.005 \\
\hline$\Delta V_{i-9}^{*}$ & -0.000 & 0.003 & $\Delta I_{t-9}^{*}{ }^{*}$ crisis dummy & 0.004 & 0.005 \\
\hline uruECMrPPP $_{t-1}$ & -0.001 & 0.009 & uruECMrPPP $\bar{t}_{t-1}{ }^{*}$ crisis dummy & -0.009 & 0.013 \\
\hline uruECMuip $_{t-1}$ & $0.001 * *$ & 0.0002 & uruECMuip $_{t-1}{ }^{*}$ crisis dummy & $-0.001 *$ & 0.0003 \\
\hline uruECMrM2 ${ }_{t-1}$ & 0.013 & 0.009 & uruECMrM2 $t-1$ *crisis dummy & 0.004 & 0.0053 \\
\hline uruECMrwage $_{t-1}$ & 0.022 & 0.029 & uruECMrwage $_{t-1}{ }^{*}$ crisis dummy & 0.036 & 0.041 \\
\hline
\end{tabular}

${ }^{t}$ Crisis dummy equals one for the period $1981(7)-1985(12)$ and it is zero otherwise.

* Denotes significance at the $5 \%$ level.

** Denotes significance at the $1 \%$ level. 


\section{Data appendix}

CHILE

Data Sample: August 1977- November 1993

List of variables:

$\mathrm{m}=\log$ of broad money $(\mathrm{M} 2)$

$\mathrm{p}=\log$ of CPI prices

$y=\log$ of industrial production

$\mathrm{I}^{\circ}=$ interest rate on deposits from 30 to 89 days

$\mathrm{p}^{*}=\log$ of US prices

$i^{*}=$ US 6 months CD rate

$\mathrm{e}=\mathrm{Pes} /$ Dollar exchange rate

$\mathrm{w}=\log$ of wage index

$\mathrm{u}=\log$ of unemployment rate

$\mathrm{sp}=$ share price index

Data frequency and data sources:

Monthly: -exchange rate (Pesos/US\$), M2, Chilean consumer price Index, US consumer price index, US 6 months CD rate, interest rate on deposits from 30 to 89 days, and share price index. Source: International Financial Statistics (IMF) . -unemployment rate. Source: UN Monthly Bulletin.

Quarterly: -industrial production and wage index. Source Central Bank of Chile.

\section{COLOMBIA}

Data sample: January 1981-June 1998

List of variables:

$\mathrm{m}=\log$ of broad money (M2)

$p=\log$ of CPI prices

$y=\log$ of industrial production

$\mathrm{I}^{\circ}=$ average interest rate for 90 day certificates of deposits

$\mathrm{p}^{*}=\log$ of US prices

$i^{*}=$ US 6 months CD rate

$\mathrm{e}=\mathrm{Pes} /$ /Dollar exchange rate

$w=\log$ of wage index

$u=\log$ of unemployment rate

$s p=$ share price index

Data frequency and data sources:

Monthly: -exchange rate (Pesos/US\$), Colombian consumer price index, US consumer prices index, US 6 months CD rate, and share price index. Source: International Financial Statistics (IMF).

- M2 and interest rate for 90 day certificates of deposit. Source: Central Bank Monthly Bulletin.

-industrial production and wage index. Source: Central Bank sources and DANE monthly bulletin.

Quarterly: -unemployment rate. Source: Central Bank and DANE monthly bulletin.

\section{DENMARK}

Data sample: January 1976-December 1993

List of variables:

$\mathrm{m}=\log$ of broad money (M2)

$\mathrm{p}=\log$ of CPI prices

$y=\log$ of industrial production

$\mathrm{I}^{\mathrm{O}}=$ average deposit rate

$\mathrm{I}^{\mathrm{a}}=$ bond rate

$p^{*=}=\log$ of German prices

$\mathrm{i}^{*}=$ German bond rate.

$\mathrm{e}=$ Krone/Deutsche Mark exchange rate

$w=\log$ of wage index

$\mathrm{u}=\log$ of unemployment rate

Data frequency and data sources:

Monthly: -exchange rate (Krone/Deutsche Mark), M2, industrial production, Danish consumer price index, German Consumer Prices Index, Danish deposit interest rate, Danish government bond yield, and German government bond yield. Source: International Financial Statistics (IMF). -unemployment rate and wage index. Source: OECD Main Economic Indicators.

\section{JAPAN}

Data sample: February 1977-December 1997

List of variables:

$\mathrm{m}=\log$ of broad money

$p=\log$ of CPI prices

$y=\log$ of industrial production

$\mathrm{I}^{\circ}=$ average $\mathrm{CD}$ rate

$\mathrm{I}^{\mathrm{a}}=$ gensaki rate

$\mathrm{I}=10$ year bond rate

$I^{*}=$ US bond rate

$\mathrm{p}^{*}=\log$ of US prices

$I^{*}=$ US bond rate.

$\mathrm{e}=$ Yen/Dollar exchange rate

$w=\log$ of wage index

$u=\log$ of unemployment rate 
$\mathrm{sp}=$ share price index

Data frequency and data sources:

Monthly: -exchange rate (Yen/US\$), Japanese consumer price index, US consumer price index, industrial production, US government bond yield, and share price index. Source: International Financial Statistics (IMF).

$-\mathrm{M} 2+\mathrm{CD}$, Gensaki rate, $\mathrm{CD}$ rate, 10-year government bond, and nominal wage. Source: OECD Main Economic Indicators.

\section{KENYA}

Data sample: December 1975-December 1997

List of variables

$\mathrm{m}=\log$ of broad money

$p=\log$ of CPI prices

$y=\log$ of annually interpolated GDP

$l^{\circ}=$ average rate on deposits from 2 to 6 months

$\mathrm{I}^{\mathrm{a}}=90$ day $\mathrm{t}$-bill rate

$I^{*}=$ US 6 months $C D$ rate

$\mathrm{p}^{*}=\log$ of US prices

$\mathrm{e}=$ Shilling/Dollar exchange rate

Data frequency and data sources:

Monthly: -exchange rate (Shillings/US\$), M2, Kenyan consumer price index, US consumer price index, interest rate on deposits from 2 to 6 months, and 90 -day treasury bill rate. Source: International Financial Statistics (IMF).

Annual: -GDP. Source: International Financial Statistic (IMF)

MALAYSIA

Data sample: June 1979-December 1996

List of variables:

$\mathrm{m}=\mathrm{log}$ of broad money

$p=\log$ of CPI prices

$y=\log$ of industrial production

$I^{\circ}=3$-month deposit interest rates for commercial banks

$I^{a}=3$-month deposit interest rates for financial institutions

$I^{*}=$ US 6 months $C D$ rate

$\mathrm{p}^{*}=\log$ of US prices

$\mathrm{e}=$ Ringgit/Dollar exchange rate

Data frequency and data sources:

Monthly: -exchange rate (Ringgit/US\$), M2, Malaysian consumer price index, US consumer price index, industrial production, and 3-month deposit interest rates for commercial banks. Source: International Financial Statistics (IMF)

- 3-month deposit interest rates for financial institutions. Source: Central Bank monthly bulletin.

\section{URUGUAY}

Data sample: August 1981-December 1997

List of variables:

$\mathrm{m}=\log$ of broad money

$p=\log$ of CPI prices

$y=\log$ of industrial production

$\mathrm{I}^{\circ}=$ interest rate on one to six months deposits:

$I^{*}=$ US 6 months $\mathrm{CD}$ rate

$p^{*}=\log$ of US prices

$\mathrm{e}=$ Peso/Dollar exchange rate

$\mathrm{w}=\log$ of wages

$\mathrm{u}=\log$ of the unemployment rate

Monthly: -exchange rate (Pesos/US\$), M2, Uruguayan consumer price index, and interest rate on 1 to 6 months deposits.Source: International Financial Statistics (IMF). -wage index. Source: Central bank bulletin.

Quarterly: -unemployment rate. Source: CEPAL "Economic Survey". -industrial production. Source: Central bank bulletin. 
TABLE A.1 - Description of the Causes and Consequences of Banking Crises

\begin{tabular}{|c|c|c|c|c|c|}
\hline Country & $\begin{array}{l}\text { Crisis } \\
\text { period }\end{array}$ & Causes & Scope of crisis & Total loss & Consequences for monetary policy \\
\hline Chile & $1981-87$ & $\begin{array}{l}\text { deep recession in } 1981 \\
\text { - } \quad \text { defichange rate crisis in } 1982 \\
\text { oligopolistic bankial organization of the } \\
\text { - unsustainable private financial deficits }\end{array}$ & $\begin{array}{l}\text { In period } 1981-83 \text {, the authorities } \\
\text { intervened in } 13 \text { banks and } 6 \\
\text { nonbank financial institutions (with } \\
78 \% \text { of outstanding loans). } 19 \% \text { of } \\
\text { loans were nonperforming at the end } \\
\text { of } 1983 \text {. }\end{array}$ & $\begin{array}{l}\text { Central bank's } \\
\text { operational losses } \\
\text { reached } 18 \% \text { of GDP } \\
\text { in } 1985 .\end{array}$ & $\begin{array}{l}\text { Significant rise in inflation (from } 9.5 \% \text { in } \\
1981 \text { to } 26.5 \% \text { in } 1985 \text { ), due to unsterilized } \\
\text { financing of massive support programs. } \\
\text { Inflation remained above } 10 \% \text { until } 1994 . \\
\text { Increase in level and volatility of money } \\
\text { multiplier at the beginning of crisis. } \\
\end{array}$ \\
\hline Colombia & 1982.88 & $\begin{array}{l}\text { banking system suffering from } \\
\text { structural weaknesses } \\
\text { strong deterioration in terms of trade in } \\
1981\end{array}$ & $\begin{array}{l}\text { The authorities intervened in } 6 \text { banks } \\
\text { and } 8 \text { finance companies. } 15 \% \text { of } \\
\text { loans were nonperforming in } 1984- \\
\text { 85. In } 1985-86 \text {, some insolvent } \\
\text { banks were nationalized. }\end{array}$ & $\begin{array}{l}\text { Estimated loss is } \\
\text { approximately } 5 \% \text { of } \\
\text { GDP }\end{array}$ & n.a. \\
\hline Denmark & $1987-92$ & $\begin{array}{l}\text { deep recession in the latter part of the } \\
1980 \mathrm{~s} \\
\text { rapid increase in monetary aggregates } \\
\text { due to financial liberalization. }\end{array}$ & $\begin{array}{l}\text { Loan losses over } 1990-92 \\
\text { represented } 9 \% \text { of loans. } 40 \text { of the } 60 \\
\text { problem banks were merged. }\end{array}$ & n.a. & n.a. \\
\hline Japan & $\begin{array}{l}\text { 1992- } \\
\text { present }\end{array}$ & $\begin{array}{l}\text { Uncontrolled financial liberalization } \\
\text { fostering sharp asset price inflation } \\
\text { Expansionary monetary policy reflected } \\
\text { in low interest rates, followed by } \\
\text { significant tightening in the proximity } \\
\text { of crisis } \\
\text { Sharp economic slowdown and falling } \\
\text { asset prices at the beginning of crisis }\end{array}$ & $\begin{array}{l}\text { Problem loans represented } 9 \% \text { of } \\
\text { GDP in } 1996 .\end{array}$ & $\begin{array}{l}\text { Rescue costs } \\
\text { probably higher than } \\
\text { US\$100bn. }\end{array}$ & $\begin{array}{l}\text { Rise in bank intermediation spreads } \\
\text { Easing of monetary policy prompted by the } \\
\text { necessity to foster economic growth }\end{array}$ \\
\hline
\end{tabular}

n.a. means that the information is not available 
TABLE A.1 - Description of the Causes and Consequences of Banking Crises, Continued

\begin{tabular}{|c|c|c|c|c|c|}
\hline Country & $\begin{array}{l}\text { Crisis } \\
\text { period }\end{array}$ & Causes & Scope of crisis & Total loss & Consequences for monetary policy \\
\hline Kenya & $\begin{array}{l}1985-89 \\
1993-95\end{array}$ & $\begin{array}{l}\text { Extremely high growth in the number } \\
\text { of financial institutions in the } 1980 \mathrm{~s}, \\
\text { with very low regulatory barriers to } \\
\text { entry and low minimum capital } \\
\text { requirements } \\
\text { Extensive insider lending, often to } \\
\text { politicians; gross mismatch between } \\
\text { maturities of assets and liabilities } \\
\text { Huge frauds in 1993, involving } 3 \\
\text { Kenyan banks } \\
\text { Heavy reliance on deposits from } \\
\text { parastatals } \\
\text { Reliance on deposits from construction } \\
\text { companies working on government } \\
\text { projects which receive their money all } \\
\text { at once after the budget is approved. }\end{array}$ & $\begin{array}{l}66 \% \text { of loans of one third of the } \\
\text { commercial banks were } \\
\text { nonperforming. } \\
\text { Between } 1984 \text { and } 1989,2 \text { local banks } \\
\text { and } 10 \text { non-bank financial institutions } \\
\text { (NBFIs) were closed or taken over. In } \\
1993 / 4 \text {, an additional } 5 \text { banks and } 10 \\
\text { NBFIs were taken over by the Central } \\
\text { Bank of Kenya, with } 2 \text { more local } \\
\text { banks in } 1996 \text {. }\end{array}$ & $\begin{array}{l}\text { Approximate losses of } \\
\text { failed local banks } \\
\text { estimated at Ksh } 9 \text { bln } \\
\text { or } \$ 158 \text { million. } \\
\\
\text { The } 1993 \text { frauds cost } \\
\text { the Central Bank of } \\
\text { Kenya total of Ksh } \\
10.2 \text { bn or } 3.2 \% \text { of } \\
1993 \text { GDP. }\end{array}$ & $\begin{array}{l}\text { Provision of large amounts of credit to distressed } \\
\text { banks was a major source of monetary expansion } \\
\text { and inflation, undermining macroeconomic } \\
\text { stability in Kenya in } 1992 / 3 \text {. } \\
\text { Depositors moved their money to more established } \\
\text { banks, which have had to lower their interest rates } \\
\text { to absorb the sudden excess liquidity. }\end{array}$ \\
\hline Malaysia & $1985-88$ & $\begin{array}{l}\text { Financial liberalization in the early } 80 \mathrm{~s}, \\
\text { spurring credit growth and price bubble } \\
\text { Terms of trade deterioration in } 1985- \\
86, \text { which induced the bubble burst } \\
\text { Annual growth plummeted from } 7 \% \text { to } \\
\text { negative } 1 \% \text { in } 1985 \text { and } 0 \% \text { in } 1986 ; \\
\text { collateral shrunk in value below the } \\
\text { loan amount it is meant to secure } \\
\text { Declining deposits, shrinking loan } \\
\text { demand, sporadic and chockingly-tight } \\
\text { liquidity } \\
\text { Almost all Malaysian banks } \\
\text { ovcrexposed to the country's weakest } \\
\text { sector: real estate }\end{array}$ & $\begin{array}{l}\text { Nonperforming loans represented } 32 \% \\
\text { of total loans in } 1988 \text {. } \\
\text { As of August } 1986,24 \text { deposit taking } \\
\text { cooperatives were suspended; } \\
\text { depositors have been able to recover } \\
\text { just } 1 / 5 \text { of their deposits. }\end{array}$ & $\begin{array}{l}\text { Reported losses } \\
\text { equivalent to } 4.7 \% \text { of } \\
\text { GNP. }\end{array}$ & $\begin{array}{l}\text { Re-imposition of controls on interest rates during } \\
1985-87 \text {. } \\
\text { Flight to quality and cash } \\
\text { Rise in money multiplier at the beginning of the } \\
\text { crisis } \\
\text { Decrease in reserve and liquidity requirements } \\
\text { with the purpose of reducing banks cost of funds }\end{array}$ \\
\hline Uruguay & $1981-87$ & $\begin{array}{l}\text { Deep world economy recession starting } \\
\text { in } 1980 \text { s } \\
\text { Collapse of the existing exchange rate } \\
\text { system, and sharp devaluation } \\
\text { High levels of debt in foreign currency } \\
\text { and soaring international interest rates }\end{array}$ & $\begin{array}{l}11 \% \text { of loans were nonperforming in } \\
1986 \text {. }\end{array}$ & $\begin{array}{l}\text { Estimated costs of } \\
\text { recapitalizing banks } \\
\text { estimated at US } \$ 350 \\
\text { million ( } 7 \% \text { of GNP). }\end{array}$ & n.a. \\
\hline
\end{tabular}

and soaring international interest rates

Sources: Brownbridge(1998), Caprio and Klingebiel (1996), Dominioni and Licandro (1989), Geraghty (1987), Hausmann and Rojas-Suarez. (1996), Koskenkyla (1994), Lindgren, Garcia, and Saal (1996), Machua (1986), Mbitiru (1986), Sheng, (1996), and Sundararajan and Balino (1991). 
TABLE A.2 - Review of Money Demand and Inflation Studies

\begin{tabular}{|c|c|}
\hline COUNTRY/AUTHORS & DESCRIPTION \\
\hline \multicolumn{2}{|l|}{ CHILE } \\
\hline Matte and Rojas (1989) & $\begin{array}{l}\text { This study estimates a reduced form money demand equation for a modified measure of M1 commonly used in Chile, } \\
\text { M1A, for the period 1978-86. The purpose of this exercise is to explain the sudden drop in money demand } \\
\text { experienced by Chile in 1984. This study does not use cointegration analysis. The demand for real M1A is modeled as } \\
\text { a function of prices, output, and the average deposit rate (the outside rate of money). Lags of money, output, and the } \\
\text { deposit rate are significant in explaining money demand. }\end{array}$ \\
\hline Apt and Quiroz (1992) & $\begin{array}{l}\text { Using cointegration analysis and error correction modeling, this paper estimates a monthly money demand function } \\
\text { for M1 A in Chile during 1983:1-1992:8. The demand for real M1A is modeled as a function of prices, output, and the } \\
\text { average deposit rate (the outside rate of money). The change in the exchange rate is also included as a determinant of } \\
\text { money demand. The final dynamic equation obtained is stable. }\end{array}$ \\
\hline Herrera and Vergara (1992) & $\begin{array}{l}\text { Using cointegration analysis and error correction modeling, this study finds a stable long-run money demand function } \\
\text { (M1A) for the period 1978:1-1991:1. }\end{array}$ \\
\hline Martner and Titleman (1993) & $\begin{array}{l}\text { This study analyzes the relationship between the real money demand (M1A), short-term interest rates (on deposits } \\
\text { from } 30 \text { to } 89 \text { days), the price level (CPI), and real income (GDP) for the period 1975-1991. The cointegration } \\
\text { analysis based on Johansen's method shows the existence of a stable long-run relationship for money (one } \\
\text { cointegrating vector). }\end{array}$ \\
\hline \multicolumn{2}{|l|}{ COLOMBIA } \\
\hline Kamas (1995) & $\begin{array}{l}\text { This paper investigates monetary policy effects under crawling peg in Colombia, during } 1975-89 \text {. A five variable } \\
\text { VAR is estimated. The variables included are: domestic credit, foreign reserves, exchange rate, prices, and income } \\
\text { (proxied by industrial production). The results reveal that neither domestic credit nor the exchange rate appear to have } \\
\text { played much of a role in determining inflation. Inflation seems to be largely inertial and the result of demand shocks. }\end{array}$ \\
\hline Rennhack and Mondino(1988) & $\begin{array}{l}\text { This paper estimates a money demand equation for the period } 1977-1985 \text {. The variables included in this study are: } \\
\text { narrow money, interest rate on } 90 \text { day certificate of deposit, exchange rate, CPI, and real GDP. }\end{array}$ \\
\hline Reinhart and Reinhart (1991) & $\begin{array}{l}\text { The authors estimate a VAR of output (real GDP), prices (cpi), monetary aggregates, interest rates on } 90 \text { day deposits, } \\
\text { the exchange rate, general and minimum wages for manufacturing employees, and export coffee prices. Results } \\
\text { indicate that money is exogenous, and past fluctuations in inflation, money growth, and exchange rate help predict the } \\
\text { exchange rate. In the end, authors settle for a } 6 \text { variable system using growth rates of narrow money, real income } \\
\text { (GDP), consumer prices (CPI), average wages in manufacturing, nominal exchange rate, and the level of nominal } \\
\text { interest rate. According to this model, monetary policy explains a large share of the variability in inflation, wages, and } \\
\text { the exchange rate. }\end{array}$ \\
\hline Herrero and Julio (1993) & $\begin{array}{l}\text { This study finds evidence of cointegration between M1, CPI, GDP, and interest rates during } 1955-91 \text { and } 1970-92 \text {. } \\
\text { The results show that money demand is stable. Tests are performed with annual and quarterly data, respectively. }\end{array}$ \\
\hline Fullerton (1993) & $\begin{array}{l}\text { This paper uses an ARMA process to study inflation in Colombia during 1967-1990. The variables used are: M1, } \\
\text { exchange rate, and CPI. The paper provides evidence that M1 and exchange rates can affect inflation. }\end{array}$ \\
\hline
\end{tabular}


TABLE A.2 - Review of Money Demand and Inflation Studies

\begin{tabular}{|c|c|}
\hline DENMARK & \\
\hline Juselius (1988) & $\begin{array}{l}\text { This paper finds one cointegrating vector reflecting a long-run money demand function for period the 1974:1 to 1985:4. } \\
\text { The variables used are real M2, domestic real demand for goods and services, bond rate, and the deposit rate. }\end{array}$ \\
\hline Juselius (1998) & $\begin{array}{l}\text { Using recently developed statistical tools for analyzing cointegrated I(2) data, this article models money (M2), income, } \\
\text { prices, and interest rates in Denmark. The final model describes the dynamic adjustment to short-run changes of the } \\
\text { process, to deviations from long-run steady states, and to several political interventions. } \\
\text { The error correction model obtained for real M2 is stable. }\end{array}$ \\
\hline \multicolumn{2}{|l|}{ JAPAN } \\
\hline Corker (1990) & $\begin{array}{l}\text { This paper estimates a demand function for broad money in Japan that explains secular trends in the income velocity of } \\
\text { broad money during the } 1970 \text { s and } 1980 \text { s and the acceleration in the decline of velocity during } 1986-1988 \text {. The paper } \\
\text { concludes that wealth effects and the opportunity cost of holding broad money can explain the developments in velocity. }\end{array}$ \\
\hline Frowen and Buscher (1990) & $\begin{array}{l}\text { This paper estimates money demand functions for three alternative monetary aggregates: M1, M2, and M2C (which } \\
\text { includes CDs in addition to M2). All monetary aggregates are deflated using CPI. The sample period is 1973:1 to 1987:4. } \\
\text { Other variables included are: Real GDP, call money rate, Gensaki rate, and Kokusai-rate. The authors implement both a } \\
\text { partial adjustment as well as a cointegration and error correction modeling framework. For M1 there is evidence of } \\
\text { cointegration, while for M2 the evidence is ambiguous. }\end{array}$ \\
\hline Hsiao and Fujiki (1998) & $\begin{array}{l}\text { This study compares results from a cointegration analysis with those from a structural modeling of money demand. The } \\
\text { data covers the period 1963:3-1993:1. The variables used are: M2+CDs, real GNP, and nominal call rate. The monetary } \\
\text { aggregate and income measure appear to be cointegrated. The error-correction model does not improve on the ADL } \\
\text { approach. }\end{array}$ \\
\hline Arize and Shwiff (1993) & $\begin{array}{l}\text { The authors estimate a money demand function for Japan for the period 1973:1-1988:4 using M2, real GNP, 3-month } \\
\text { Gensaki, weighted average of the interest rate on three-month certificates of deposits, the guideline three month deposit } \\
\text { rate, real wealth, and the real exchange rate. The variables are I(1) and the results show the existence of one cointegrating } \\
\text { vector. Money demand appears stable. }\end{array}$ \\
\hline Yoshida (1990) & $\begin{array}{l}\text { This paper estimates an error correction money demand function for the period: } 1968: 1-1989: 1 \text {. The variables used in this } \\
\text { study are: real M2+CDs, real GNP, the coupon rate on 5-year debentures, and the coefficient of variation of Nikkei stock } \\
\text { average. One cointegrating relation is found between money and real income. Money demand appears stable. }\end{array}$ \\
\hline Soejima (1996) & $\begin{array}{l}\text { Using data from the period 1957:3 to } 1994: 1 \text {, the author studies whether there is a long-run relationship between real } \\
\text { GDP, money supply (M1), and the price level. This study concludes that real and nominal GDP series can be seen as } \\
\text { stationary processes around a deterministic trend with structural change, while M1 is non-stationary. The study indicates } \\
\text { that the cointegration between the three variables, which previous studies found, arises from a mispecification of the time } \\
\text { series model, and that the instability in the demand function arises from the non-stationarity of M1. }\end{array}$ \\
\hline
\end{tabular}


TABLE A.2 - Review of Money Demand and Inflation Studies, Continued

\begin{tabular}{|c|c|}
\hline Arize (1990) & $\begin{array}{l}\text { This study estimates a money demand function for the periods 1973:2-1981:4 and 1973:2-1986:4 using OLS in a setup of } \\
\text { real adjustment analysis. The variables used are: real M1, domestic real income, bond yield rate, and a number of dummy } \\
\text { variables. The split in the sample is used to determine the stability of the model after the financial innovation period. No } \\
\text { evidence of structural change is found. }\end{array}$ \\
\hline $\begin{array}{l}\text { Hoffmaister and Schinasi } \\
\text { (1994) }\end{array}$ & $\begin{array}{l}\text { This paper estimates a VAR of call money rate, growth of M2, real output gap, land price inflation, and the CPI over the } \\
\text { period 1986-1993. The study finds monetary factors are the most important variables behind asset price inflation. With } \\
\text { respect to the CPI, it seems that the capacity of monetary factors to influence the consumer price level has decreased due } \\
\text { to structural changes. }\end{array}$ \\
\hline Sekine (1998) & $\begin{array}{l}\text { This paper examines the demand for broad money in Japan from } 1975 \text { to } 1994 \text {. In spite of the large shocks due to the } \\
\text { process of financial liberalization and the subsequent "bubble" economy of the } 1990 \text { s, the paper confirms that a stable } \\
\text { money demand function can be found by taking proper account of the financial liberalization and the wealth effects. }\end{array}$ \\
\hline \multicolumn{2}{|r|}{ (1) } \\
\hline Habibulla (1990) & $\begin{array}{l}\text { This study tests whether wealth is a better proxy for the scale variable than current income for the Malaysian money } \\
\text { demand. The sample period analyzed is: } 1960-1984 \text {. The variables employed in this study are: M1, M2, M3, GNP } \\
\text { deflated by CPI, 3-month T-bill rate, rate of return on the monetary aggregates of interest, and the growth rate of CPI. } \\
\text { After using a partial adjustment mechanism to specify the models, the authors conclude that the scale variable should be } \\
\text { defined in terms of permanent income rather than current income. }\end{array}$ \\
\hline Dhakal and Kandil (1993) & $\begin{array}{l}\text { This paper tests the hypothesis that inflation is a monetary phenomenon for a group of Asian countries. The model } \\
\text { includes the following variables: CPI, M1, industrial production index, money market interest rates, unit value of imports, } \\
\text { and foreign nominal interest rates. The results of OLS estimations for Malaysia show that changes in money supply are } \\
\text { important and significant in predicting prices. }\end{array}$ \\
\hline Abdullah and Yusop (1996) & $\begin{array}{l}\text { This paper investigates the causal relationship between money supply and inflation during the period } 1970-92 \text {. The } \\
\text { variables used are: } \mathrm{M} 1, \mathrm{M} 2 \text { and the inflation rate(CPI). After applying Granger methodology, results reveal that money } \\
\text { supply causes inflation independently of the monetary aggregate used. }\end{array}$ \\
\hline Yusoff (1988) & $\begin{array}{l}\text { This paper estimates six behavioral equations with the purpose of analyzing the effects of monetary policy on inflation, } \\
\text { balance of payments (BOP), and real output. The sample covers the period 1960-1981. The method of estimation is 2SLS } \\
\text { and non-linear 3SLS. The equation for inflation posits that inflation is a function of changes in money and changes in } \\
\text { foreign prices. Both factors appear to be significant in the model. }\end{array}$ \\
\hline Chye and Semudram & $\begin{array}{l}\text { The objective of this study is to appraise the monetarist and neo-keynesian hypotheses in their ability to predict inflation } \\
\text { in Malaysia. The paper covers the period: 1960-1986. The models employed were estimated by OLS and showed support } \\
\text { for the monetarist view of inflation. }\end{array}$ \\
\hline \multicolumn{2}{|l|}{ KENȲA } \\
\hline Page (1993) & $\begin{array}{l}\text { This study estimates an equation relating inflation to income and money supply (M2) and an equation representing money } \\
\text { demand as a function of past income, expected inflation, and the T-bill rate. The money demand function for M1 appears } \\
\text { to be stable. }\end{array}$ \\
\hline
\end{tabular}


TABLE A.2 - Review of Money Demand and Inflation Studies, Continued

\begin{tabular}{|c|c|}
\hline Ndung'u (1997) & $\begin{array}{l}\text { This paper estimates a VAR with money, the domestic price level, the exchange rate index, foreign price index, real } \\
\text { output, and the interest rate. The period analyzed is } 1970-1993 \text {. One cointegration relationship is found among the } \\
\text { exchange rate, CPI, and foreign prices. Causality tests indicate that exchange rate changes and domestic rate of inflation } \\
\text { changes predict each other. The world rate of inflation does not predict the domestic rate of inflation. Tests for inflation } \\
\text { show a structural break in 1982, when the crawling peg exchange rate was adopted. }\end{array}$ \\
\hline Chakrabarti (1992) & $\begin{array}{l}\text { This study aims at investigating the influence of various factors on inflation in Kenya. The sample period is: } 1972-1989 \text {, } \\
\text { and the variables employed are: CPI, World Bank's manufacturing unit value index (as a proxy for world price), } \\
\text { exchange rate, money per unit of output, nominal interest rate on savings deposits, wage variables, lagged CPI, oil price, } \\
\text { and the government budget deficit. The empirical framework is OLS. The monetary aggregate used is M2. Aside from } \\
\text { other results, this study verifies that both the stock of money and exchange rate changes influence prices. }\end{array}$ \\
\hline Adam (1992) & $\begin{array}{l}\text { This paper studies money demand in the period 1973-1990. The variables included are: GNP adjusted for changes in } \\
\text { terms of trade, GNP adjusted for changes in total final expenditures, CPI, T-bill rate, official exchange rate vis a vis the } \\
\text { US dollar, and narrow money. Using a general to specific modeling approach with the ECM term included, the study } \\
\text { finds one cointegrating vector between income and money. }\end{array}$ \\
\hline Adam (1992) & $\begin{array}{l}\text { This study covers the period: } 1972-1990 \text {. VAR is estimated for each of } 5 \text { monetary aggregates, plus income, inflation, T- } \\
\text { bill interest, and exchange rate depreciation. The results indicate the existence of two cointegration vectors, one } \\
\text { representing a money demand function and the other a relationship between interest rates and inflation. Using recursive } \\
\text { estimation, the author confirms money demand stability. }\end{array}$ \\
\hline Ndung'u (1993) & $\begin{array}{l}\text { This paper investigates the determinants of inflation in the period 1970-91. The variables used are: monetary base, real } \\
\text { gross national income, and the annualized treasury discount rate. Two cointegrating vectors are found and the estimation } \\
\text { of an ECM model shows that money supply affects inflation, but not money demand. In the second stage, the model } \\
\text { employed allows for an open economy. The variables added are the nominal exchange rate and the foreign price index. } \\
\text { Three cointegrating relationships are found: a money demand function, a purchasing power parity function, and a third } \\
\text { vector, which is not identifiable. }\end{array}$ \\
\hline Mwega and Killick (1990) & $\begin{array}{l}\text { This study performs OLS regressions of changes in the CPI on the growth of real income, changes in money supply (M2), } \\
\text { changes in import prices, and changes in previous year's inflation rate. The estimation periods are 1971-82 and 1971-88, } \\
\text { respectively. The authors also estimate a short-run money demand function for 1973:3-1988:4, using M1, M2 and M3 as } \\
\text { monetary aggregates. The results show that the government may be able to influence demand for money by shifting } \\
\text { interest rates. Money demand functions were found to be stable, but more so for narrow money that for broader } \\
\text { aggregates. }\end{array}$ \\
\hline Darrat (1985) & $\begin{array}{l}\text { This paper estimates money demand equations for M1 and M2 during 1969-78 using as variables: real GNP, CPI, and an } \\
\text { average of quarterly short-term interest rates in major OECD countries. Money demand functions are found to be stable. }\end{array}$ \\
\hline \multicolumn{2}{|l|}{ URUGUAY } \\
\hline Graziani (1988) & $\begin{array}{l}\text { This paper tests an inflation model where inflation is modeled as a function of lagged money, output, interest rates, } \\
\text { export, and import prices. The sample period considered is } 1952-1981 \text { and the method of estimation is OLS. Money and } \\
\text { import prices seem to have the largest effect on inflation. }\end{array}$ \\
\hline
\end{tabular}


Table A.3: Unit Root Tests

\begin{tabular}{|c|c|c|c|c|c|c|c|}
\hline Country & Variable & $\overline{t-a d f}$ & befa & sigma & lag & $t$-prob & $F-p r o b$ \\
\hline \multirow[t]{22}{*}{ Chile } & $\mathrm{m}$ & -2.724 & 0.966 & 0.029 & 3.000 & 0.001 & 0.079 \\
\hline & $\mathrm{p}$ & -2.061 & 0.976 & 0.008 & 1.000 & 0.000 & 0.386 \\
\hline & $\mathrm{y}$ & -2.071 & 0.919 & 0.039 & 12.000 & 0.063 & 0.081 \\
\hline & $\mathrm{w}$ & $-4.374^{* *}$ & 0.899 & 0.022 & 10.000 & 0.001 & 0.1189 \\
\hline & $\mathrm{u}$ & -1.557 & 0.975 & 0.070 & 0.000 & - & 0.5223 \\
\hline & e & -0.889 & 0.993 & 0.022 & 1.000 & 0.000 & 0.3969 \\
\hline & $i^{\circ}$ & $-5.495^{* *}$ & 0.705 & 8.805 & 0.000 & - & 0.3034 \\
\hline & $m-p$ & -2.109 & 0.974 & 0.029 & 3.000 & 0.000 & 0.194 \\
\hline & $w-p$ & -2.532 & 0.928 & 0.026 & 1.000 & 0.006 & 0.187 \\
\hline & $\mathrm{p}-\mathrm{e}$ & -1.223 & 0.990 & 0.021 & 1.000 & 0.000 & 0.577 \\
\hline & $\mathrm{dm}$ & $-5.288^{* *}$ & 0.392 & 0.029 & 2.000 & 0.001 & 0.223 \\
\hline & $\mathrm{dp}$ & $-7.596^{* *}$ & 0.488 & 0.008 & 0.000 & - & 0.465 \\
\hline & dy & -2.918 & -0.423 & 0.038 & 13.000 & 0.002 & - \\
\hline & $\mathrm{dw}$ & -2.508 & 0.387 & 0.022 & 9.000 & 0.028 & 0.140 \\
\hline & du & $-12.982 * *$ & -0.003 & 0.071 & 0.000 & - & 0.666 \\
\hline & de & $-7.037^{* *}$ & 0.543 & 0.022 & 0.000 & - & 0.507 \\
\hline & $d i^{\circ}$ & $-12.680^{* *}$ & -0.365 & 9.175 & 1.000 & 0.000 & 0.199 \\
\hline & $d(m-p)$ & $-9.953^{* *}$ & -0.180 & 0.027 & 1.000 & 0.781 & 0.056 \\
\hline & $d(w-p)$ & $-17.310^{* *}$ & -0.223 & 0.024 & 0.000 & - & 0.346 \\
\hline & $d(p-e)$ & $-7.467 * *$ & 0.499 & 0.021 & 0.000 & - & 0.764 \\
\hline & $\mathrm{d}^{2} \mathrm{~m}$ & $-8.735^{* *}$ & -3.821 & 0.029 & 6.000 & 0.012 & 0.317 \\
\hline & $d^{2} p$ & $-8.589 * *$ & -1.801 & 0.009 & 5.000 & 0.012 & 0.727 \\
\hline \multirow[t]{20}{*}{ Colombia } & $\mathrm{m}$ & -2.103 & 0.971 & 0.013 & 12.000 & 0.007 & 0.198 \\
\hline & $\mathrm{p}$ & -2.100 & 0.983 & 0.006 & 11.000 & 0.017 & 0.213 \\
\hline & $y$ & -2.336 & 0.869 & 0.033 & 2.000 & 0.001 & 0.389 \\
\hline & e & -0.426 & 0.998 & 0.014 & 1.000 & 0.000 & 0.204 \\
\hline & $\mathrm{i}^{\circ}$ & -3.423 & 0.913 & 1.119 & 3.000 & 0.002 & 0.181 \\
\hline & $w$ & -1.437 & 0.961 & 0.014 & 13.000 & 0.001 & - \\
\hline & $\mathrm{u}$ & -1.456 & 0.917 & 0.074 & 0.000 & - & 0.569 \\
\hline & $m-p$ & -1.751 & 0.975 & 0.015 & 1.000 & 0.001 & 0.252 \\
\hline & $w-p$ & -2.223 & 0.919 & 0.016 & 12.000 & 0.000 & 0.139 \\
\hline & $\mathrm{p}-\mathrm{e}$ & -1.062 & 0.995 & 0.014 & 1.000 & 0.000 & 0.578 \\
\hline & $\mathrm{dm}$ & $-3.848^{*}$ & 0.281 & 0.013 & 11.000 & 0.014 & 0.155 \\
\hline & $\mathrm{dp}$ & -3.005 & 0.578 & 0.006 & 9.000 & 0.079 & 0.082 \\
\hline & dy & $-15.794^{* *}$ & -0.942 & 0.033 & 1.000 & 0.000 & 0.157 \\
\hline & de & $-9.59 * *$ & 0.326 & 0.014 & 0.000 & - & 0.259 \\
\hline & $\mathrm{di}^{\circ}$ & $-9.769 * *$ & 0.274 & 1.161 & 0.000 & - & 0.140 \\
\hline & $d w$ & -2.580 & -0.306 & 0.014 & 12.000 & 0.001 & 0.053 \\
\hline & $\mathrm{du}$ & $-8.539^{* *}$ & -0.078 & 0.073 & 0.000 & - & 0.827 \\
\hline & $d(m-p)$ & $-10.519 * *$ & 0.230 & 0.015 & 0.000 & - & 0.356 \\
\hline & $d(w-p)$ & $-3.452^{*}$ & -0.518 & 0.016 & 11.000 & 0.000 & 0.410 \\
\hline & $d(p-e)$ & $-9.221^{* *}$ & 0.360 & 0.015 & 0.000 & - & 0.656 \\
\hline
\end{tabular}

For each variable the columms report the augmented Dickey Fuller (ADF) statistic on the final equation (t-adf), the estimated coefficient on the lagged level that is being tested for a unit value (beta), the estimated equation standard error (sigma), the lag length of the ADF regression (lag), the tail probability on the longest lag of the final regression (t-prob), and the tail probability of the F-statistic for the lags dropped (F-prob).

Rejection of the null hypothesis of a unit root is denoted by * and ** for the $5 \%$ and $1 \%$ levels. Definition of variables: $m$ is a measure of broad money, $p$ refers to the CPI, $y$ is a measure of output, $w$ is a measure of wages, $u$ is a measure of the unemployment rate, $\mathrm{e}$ is the exchange rate (usually in terms of domestic currency per US\$), $i^{a}$ represents the own rate of $m 2, i^{A}$ represents the alternative (outside) rate, $i{ }^{*}$ represents the foreign interest rate. All variables except interest rates are in logs. Notation: $d$ refers to the change in the variable. $d^{2}$ refers to the second difference of a variable. 
Table A.3: Unit Root Tests, continued

\begin{tabular}{|c|c|c|c|c|c|c|c|}
\hline Country & Variable & t-adf & beta & sigma & $\operatorname{lag}$ & $t-p r o b$ & $F-p r o b$ \\
\hline \multirow[t]{28}{*}{ Denmark } & $m$ & -1.739 & 0.981 & 0.013 & 12.000 & 0.005 & 0.198 \\
\hline & $\mathrm{p}$ & -1.304 & 0.995 & 0.004 & 0.000 & - & 0.644 \\
\hline & $y$ & -2.787 & 0.881 & 0.028 & 1.000 & 0.000 & 0.127 \\
\hline & $e(\mathrm{kr} / \mathrm{dm})$ & -2.076 & 0.980 & 0.007 & 1.000 & 0.001 & 0.2445 \\
\hline & $\mathrm{p}^{*}$ (german) & -1.284 & 0.993 & 0.003 & 1.000 & 0.000 & 0.0576 \\
\hline & $i^{\circ}$ & -1.484 & 0.978 & 0.327 & 0.000 & - & 0.082 \\
\hline & $i^{A}$ & -2.770 & 0.951 & 0.543 & 12.000 & 0.005 & 0.489 \\
\hline & $i^{*}\left(\right.$ german ib $\left.i^{b}\right)$ & -2.773 & 0.963 & 0.231 & 11.000 & 0.008 & 0.395 \\
\hline & $\mathrm{w}$ & -1.294 & 0.988 & 0.007 & 12.000 & 0.008 & 0.894 \\
\hline & $\mathrm{u}$ & $-3.749^{*}$ & 0.935 & 0.030 & 12.000 & 0.000 & 0.066 \\
\hline & $\mathrm{m}-\mathrm{p}$ & -2.357 & 0.971 & 0.014 & 12.000 & 0.005 & 0.469 \\
\hline & $w-p$ & -0.855 & 0.983 & 0.008 & 11.000 & 0.033 & 0.162 \\
\hline & p-e & -1.527 & 0.969 & 0.009 & 0.000 & - & 0.591 \\
\hline & $\mathrm{dm}$ & -2.378 & 0.450 & 0.013 & 11.000 & 0.010 & 0.545 \\
\hline & $\mathrm{dp}$ & $-12.090^{* *}$ & 0.123 & 0.004 & 0.000 & - & 0.842 \\
\hline & dy & $-13.628 * *$ & -0.618 & 0.028 & 1.000 & 0.005 & 0.153 \\
\hline & $\mathrm{de}(\mathrm{kr} / \mathrm{dm})$ & $-10.710^{* *}$ & 0.232 & 0.008 & 0.000 & - & 0.274 \\
\hline & $\mathrm{dp}^{*}$ (german) & $-9.408^{* *}$ & 0.358 & 0.003 & 0.000 & - & 0.180 \\
\hline & $\mathrm{di}^{\circ}$ & $-11.774 * *$ & 0.195 & 0.317 & 0.000 & - & 0.687 \\
\hline & $\mathrm{di}^{\mathrm{A}}$ & $-4.408^{* *}$ & 0.112 & 0.553 & 11.000 & 0.002 & 0.227 \\
\hline & $\mathrm{di}^{*}($ german$)$ & $-9.314 * *$ & 0.392 & 0.236 & 0.000 & - & 0.286 \\
\hline & $d w$ & $-3.787^{*}$ & -0.336 & 0.007 & 11.000 & 0.005 & 0.347 \\
\hline & $\mathrm{du}$ & -2.688 & 0.479 & 0.030 & 12.000 & 0.003 & 0.796 \\
\hline & $d(m-p)$ & -2.350 & 0.484 & 0.014 & 11.000 & 0.005 & 0.777 \\
\hline & $d(w-p)$ & $-5.675^{* *}$ & -1.110 & 0.008 & 10.000 & 0.026 & 0.196 \\
\hline & $d(p-e)$ & $-11.974 * *$ & 0.125 & 0.009 & 0.000 & - & 0.709 \\
\hline & $d^{2} m 2$ & $-6.669 * *$ & -6.516 & 0.014 & 10.000 & 0.000 & 0.466 \\
\hline & $d^{2} p$ & $-8.265^{* *}$ & -5.683 & 0.004 & 10.000 & 0.003 & 0.651 \\
\hline
\end{tabular}


Table A.3: Unit Root Tests, continued

\begin{tabular}{|c|c|c|c|c|c|c|c|}
\hline Country & Variable & $t$-adf & beta & sigma & $\operatorname{lag}$ & $t$-prob & F-prob \\
\hline \multirow[t]{28}{*}{ Japan } & $\mathrm{m}$ & -0.593 & 0.997 & 0.006 & 13.000 & 0.001 & - \\
\hline & $\mathrm{p}$ & -2.611 & 0.980 & 0.004 & 12.000 & 0.008 & 0.720 \\
\hline & $\mathrm{y}$ & -1.904 & 0.973 & 0.013 & 9.000 & 0.000 & 0.597 \\
\hline & e & -2.466 & 0.964 & 0.029 & 11.000 & 0.035 & 0.856 \\
\hline & $\mathrm{sp}$ & -0.656 & 0.995 & 0.039 & 9.000 & 0.027 & 0.348 \\
\hline & $\mathrm{i}^{\mathrm{A}}$ & -2.882 & 0.968 & 0.286 & 3.000 & 0.000 & 0.109 \\
\hline & $i^{0}$ & -2.518 & 0.969 & 0.315 & 2.000 & 0.064 & 0.068 \\
\hline & $\mathrm{i}^{\mathrm{b}}(10 \mathrm{yrOECD})$ & -3.150 & 0.925 & 0.373 & 0.000 & - & 0.164 \\
\hline & $w$ & -2.127 & 0.917 & 0.018 & 13.000 & 0.004 & - \\
\hline & $\mathrm{u}$ & -0.852 & 0.986 & 0.033 & 2.000 & 0.000 & 0.434 \\
\hline & $\mathrm{m}-\mathrm{p}$ & -0.934 & 0.993 & 0.007 & 13.000 & 0.020 & - \\
\hline & $w-p$ & -1.855 & 0.838 & 0.019 & 13.000 & 0.005 & - \\
\hline & $\mathrm{p}-\mathrm{e}$ & -2.279 & 0.962 & 0.029 & 11.000 & 0.037 & 0.839 \\
\hline & $\mathrm{dm}$ & -2.474 & 0.508 & 0.006 & 13.000 & 0.009 & - \\
\hline & $d p$ & -2.525 & 0.514 & 0.004 & 11.000 & 0.014 & 0.370 \\
\hline & dy & -3.209 & 0.276 & 0.013 & 8.000 & 0.001 & 0.320 \\
\hline & de & $-10.513 * *$ & 0.336 & 0.029 & 0.000 & - & 0.377 \\
\hline & dsp & $-4.279 * *$ & 0.293 & 0.039 & 11.000 & 0.048 & 0.624 \\
\hline & $\mathrm{di}^{\mathrm{A}}$ & $-4.815 * *$ & 0.560 & 0.288 & 4.000 & 0.020 & 0.108 \\
\hline & $\mathrm{di}^{\circ}$ & $-9.341 * *$ & 0.452 & 0.324 & 0.000 & - & 0.062 \\
\hline & $\mathrm{di}^{\mathrm{b}}(10 \mathrm{yrOECD})$ & $-14.481^{* *}$ & 0.053 & 0.382 & 0.000 & - & 0.130 \\
\hline & $d w$ & $-3.997^{*}$ & -2.657 & 0.018 & 13.000 & 0.009 & - \\
\hline & $d u$ & $-15.957 * *$ & -0.527 & 0.033 & 1.000 & 0.000 & 0.422 \\
\hline & $d(m-p)$ & -2.489 & 0.551 & 0.007 & 13.000 & 0.004 & - \\
\hline & $d(w-p)$ & $-4.214^{* *}$ & -3.212 & 0.018 & 13.000 & 0.022 & - \\
\hline & $d(p-e)$ & $-10.679^{* *}$ & 0.322 & 0.029 & 0.000 & - & 0.330 \\
\hline & $d^{2} m$ & $-5.893 * *$ & -7.453 & 0.006 & 12.000 & 0.002 & 0.961 \\
\hline & $d^{2} p$ & $-8.242 * *$ & -7.059 & 0.004 & 10.000 & 0.002 & 0.722 \\
\hline \multirow[t]{18}{*}{ Kenya } & $\mathrm{m}$ & -0.694 & 0.992 & 0.024 & 12.000 & 0.007 & 0.860 \\
\hline & $\mathrm{p}$ & -1.462 & 0.990 & 0.015 & 3.000 & 0.000 & 0.619 \\
\hline & $y$ & -2.015 & 0.980 & 0.007 & 0.000 & - & 0.937 \\
\hline & e & -3.276 & 0.965 & 0.028 & 5.000 & 0.005 & 0.238 \\
\hline & $i^{o}$ & -3.420 & 0.947 & 0.783 & 2.000 & 0.000 & 0.211 \\
\hline & $i^{A}$ & $-4.334 * *$ & 0.893 & 2.093 & 11.000 & 0.003 & 0.871 \\
\hline & $\mathrm{i}^{*}$ (US) & -2.838 & 0.954 & 0.552 & 13.000 & 0.004 & - \\
\hline & $m-p$ & -2.502 & 0.945 & 0.027 & 12.000 & 0.004 & 0.365 \\
\hline & p-e & -2.567 & 0.917 & 0.034 & 12.000 & 0.007 & 0.449 \\
\hline & $\mathrm{dm}$ & $-3.796^{*}$ & 0.162 & 0.024 & 11.000 & 0.011 & 0.411 \\
\hline & $\mathrm{dp}$ & -3.208 & 0.545 & 0.016 & 13.000 & 0.047 & - \\
\hline & dy & $-16.378^{* *}$ & -0.023 & 0.007 & 0.000 & - & 0.876 \\
\hline & de & $-4.525 * *$ & 0.574 & 0.029 & 4.000 & 0.019 & 0.131 \\
\hline & $\mathrm{di}^{\circ}$ & $-4.647 * *$ & 0.259 & 0.794 & 13.000 & 0.028 & - \\
\hline & $\mathrm{di}^{\mathrm{A}}$ & $-5.719 * *$ & 0.274 & 2.195 & 8.000 & 0.002 & 0.090 \\
\hline & $\mathrm{di}^{*}(\mathrm{US})$ & $-4.160 * *$ & 0.100 & 0.561 & 12.000 & 0.009 & 0.297 \\
\hline & $d(m-p)$ & $-7.026 * *$ & 0.200 & 0.028 & 2.000 & 0.001 & 0.066 \\
\hline & $d(p-e)$ & $-6.466 * *$ & -0.618 & 0.034 & 13.000 & 0.028 & - \\
\hline
\end{tabular}


Table A.3: Unit Root Tests, continued

\begin{tabular}{|c|c|c|c|c|c|c|c|}
\hline Country & Variable & $t-a d f$ & beta & sigma & $\operatorname{lag}$ & t-prob & $F-p r o b$ \\
\hline \multirow[t]{20}{*}{ Malaysia } & $\mathrm{m}$ & 0.424 & 1.004 & 0.014 & 0.000 & - & 0.733 \\
\hline & $\mathrm{p}$ & -1.909 & 0.982 & 0.004 & 4.000 & 0.011 & 0.087 \\
\hline & $\mathrm{y}$ & $-4.253 * *$ & 0.748 & 0.045 & 1.000 & 0.000 & 0.265 \\
\hline & $\mathrm{e}$ & -1.463 & 0.974 & 0.010 & 13.000 & 0.011 & - \\
\hline & $i^{0}$ & -2.197 & 0.969 & 0.386 & 2.000 & 0.016 & 0.123 \\
\hline & $\mathrm{i}^{\mathrm{A}}$ & -2.825 & 0.944 & 0.481 & 10.000 & 0.001 & 0.401 \\
\hline & $i^{*}(\mathrm{US} 6 \mathrm{~m} \mathrm{~cd})$ & -2.920 & 0.934 & 0.496 & 13.000 & 0.000 & - \\
\hline & $\mathrm{m}-\mathrm{p}$ & -0.231 & 0.997 & 0.015 & 0.000 & - & 0.828 \\
\hline & $\mathrm{p}-\mathrm{e}$ & -0.858 & 0.989 & 0.010 & 13.000 & 0.004 & - \\
\hline & $\mathrm{dm}$ & $-15.361^{* *}$ & -0.129 & 0.014 & 0.000 & - & 0.891 \\
\hline & $\mathrm{dp}$ & -2.187 & 0.674 & 0.004 & 13.000 & 0.018 & - \\
\hline & dy & $-23.614^{* *}$ & -0.510 & 0.047 & 0.000 & - & 0.078 \\
\hline & $\mathrm{de}$ & $-4.378^{* *}$ & -0.116 & 0.010 & 12.000 & 0.010 & 0.378 \\
\hline & $\mathrm{di}^{\circ}$ & $-11.584 * *$ & 0.184 & 0.392 & 0.000 & - & 0.142 \\
\hline & $\mathrm{di}^{\mathrm{A}}$ & $-3.679^{*}$ & 0.300 & 0.491 & 9.000 & 0.005 & 0.435 \\
\hline & $\mathrm{di}^{*}(\mathrm{US} 6 \mathrm{~m} \mathrm{~cd})$ & $-3.802^{*}$ & 0.263 & 0.501 & 12.000 & 0.001 & 0.947 \\
\hline & $d(m-p)$ & $-15.631 * *$ & -0.145 & 0.015 & 0.000 & - & 0.966 \\
\hline & $d(p-e)$ & $-3.731^{*}$ & 0.211 & 0.010 & 12.000 & 0.003 & 0.151 \\
\hline & $d^{2} m$ & $-7.824 * *$ & -4.958 & 0.015 & 8.000 & 0.046 & 0.560 \\
\hline & $d^{2} p$ & $-6.601 * *$ & -5.783 & 0.004 & 12.000 & 0.009 & 0.178 \\
\hline \multirow{24}{*}{ Uruguay } & $\mathrm{m}$ & -0.533 & 0.995 & 0.031 & 6.000 & 0.013 & 0.100 \\
\hline & $\mathrm{p}$ & 0.066 & 1.000 & 0.016 & 8.000 & 0.000 & 0.572 \\
\hline & $\mathrm{y}$ & -2.938 & 0.758 & 0.045 & 0.000 & - & 0.326 \\
\hline & $\mathrm{e}$ & -1.439 & 0.979 & 0.057 & 0.000 & - & 0.948 \\
\hline & $i^{0}$ & -2.162 & 0.971 & 2.958 & 4.000 & 0.021 & 0.086 \\
\hline & $i^{*}($ US cd rate) & -2.491 & 0.958 & 0.328 & 5.000 & 0.034 & 0.128 \\
\hline & w & -0.668 & 0.994 & 0.028 & 8.000 & 0.000 & 0.735 \\
\hline & $u$ & -2.814 & 0.648 & 0.099 & 0.000 & - & 0.071 \\
\hline & $m-p$ & -2.634 & 0.926 & 0.038 & 0.000 & - & 0.315 \\
\hline & $w-p$ & $-3.747^{*}$ & 0.894 & 0.024 & 4.000 & 0.000 & 0.389 \\
\hline & $\mathrm{p}-\mathrm{e}$ & $-5.666^{* *}$ & 0.853 & 0.053 & 0.000 & - & 0.627 \\
\hline & $\mathrm{dm}$ & $-3.657^{*}$ & 0.463 & 0.032 & 4.000 & 0.016 & 0.079 \\
\hline & $d p$ & -2.608 & 0.752 & 0.016 & 7.000 & 0.000 & 0.653 \\
\hline & dy & $-10.690 * *$ & -0.352 & 0.045 & 0.000 & - & 0.979 \\
\hline & de & $-13.792^{* *}$ & -0.059 & 0.058 & 0.000 & - & 0.819 \\
\hline & $d i^{o}$ & $-7.063 * *$ & 0.260 & 2.981 & 3.000 & 0.012 & 0.102 \\
\hline & $\mathrm{di}^{*}(\mathrm{US} \mathrm{cd})$ & $-8.905 * *$ & 0.388 & 0.332 & 0.000 & - & 0.202 \\
\hline & $\mathrm{dw}$ & -2.586 & 0.678 & 0.027 & 7.000 & 0.000 & 0.797 \\
\hline & $\mathrm{du}$ & $-9.967 * *$ & -0.452 & 0.098 & 0.000 & - & 0.136 \\
\hline & $\mathrm{d}(\mathrm{m}-\mathrm{p})$ & $-13.846^{* *}$ & -0.062 & 0.039 & 0.000 & - & 0.236 \\
\hline & $\mathrm{d}(\mathrm{w}-\mathrm{p})$ & $-4.842^{* *}$ & 0.172 & 0.025 & 3.000 & 0.000 & 0.304 \\
\hline & $d(p-e)$ & $-14.772^{* *}$ & -0.128 & 0.057 & 0.000 & - & 0.982 \\
\hline & $\mathrm{d}^{2} \mathrm{~m} 2$ & $-6.717^{* *}$ & -7.383 & 0.031 & 10.000 & 0.043 & 0.900 \\
\hline & $\mathrm{d}^{2} \mathrm{p}$ & $-10.483^{* *}$ & -3.628 & 0.016 & 6.000 & 0.000 & 0.483 \\
\hline
\end{tabular}


Table A.4- Cointegration Results: Lag Length Selection and Eigenvalue Statistics - MONETARY SECTOR

\begin{tabular}{|c|c|c|c|c|c|c|c|c|}
\hline & \multirow[b]{2}{*}{$\begin{array}{c}\text { Selected System } \\
\text { Lag Length }\end{array}$} & \multirow[b]{2}{*}{$\begin{array}{c}\text { Ho: } \\
\text { Rank=p }\end{array}$} & \multicolumn{3}{|c|}{ Maximal Eigenvalue } & \multicolumn{3}{|c|}{ Eigenvalue Trace } \\
\hline & & & Statistic & $\begin{array}{l}\text { Statistic, } \\
\text { adjusted for } \\
\text { degrees of } \\
\text { freedom }\end{array}$ & $\begin{array}{l}95 \% \text { crifical } \\
\text { value }\end{array}$ & Statistic & $\begin{array}{l}\text { Statistic, } \\
\text { adjusted for } \\
\text { degrees of } \\
\text { freedom } \\
\end{array}$ & $\begin{array}{l}95 \% \text { critical } \\
\text { value }\end{array}$ \\
\hline \multirow[t]{4}{*}{ Chile } & \multirow[t]{4}{*}{3} & $p=0$ & $70.46^{* *}$ & $65.81^{* *}$ & 31.5 & $125.6^{* *}$ & $117.3^{* *}$ & 63.0 \\
\hline & & $p<=1$ & $27.95^{*}$ & $26.11^{*}$ & 25.5 & $55.12^{* *}$ & $51.48 * *$ & 42.4 \\
\hline & & $p<=2$ & 16.46 & 15.37 & 19.0 & $27.16^{*}$ & $25.37^{*}$ & 25.3 \\
\hline & & $p<=3$ & 10.71 & 10.00 & 12.3 & 10.71 & 10.00 & 12.3 \\
\hline \multirow[t]{4}{*}{ Colombia } & \multirow[t]{4}{*}{13} & $p=0$ & 29.66 & 21.79 & 31.5 & $74.98 * *$ & 55.09 & 63.0 \\
\hline & & $p<=1$ & $26.04^{*}$ & 19.13 & 25.5 & $45.32 *$ & 33.3 & 42.4 \\
\hline & & $p<=2$ & 13.52 & 9.93 & 19.0 & 19.29 & 14.17 & 25.3 \\
\hline & & $p<=3$ & 5.771 & 4.24 & 12.3 & 5.771 & 4.24 & 12.3 \\
\hline \multirow[t]{5}{*}{ Denmark } & \multirow[t]{5}{*}{12} & $p=0$ & $96 * *$ & $67.49 * *$ & 37.5 & $191 * *$ & $134.3^{* *}$ & 87.3 \\
\hline & & $\mathrm{p}<=1$ & $61.35^{* *}$ & $43.13^{* *}$ & 31.5 & $94.98 * *$ & $66.77^{*}$ & 63.0 \\
\hline & & $p<=2$ & 20.09 & 14.212 & 25.5 & 33.63 & 23.64 & 42.4 \\
\hline & & $p<=3$ & 10.84 & 7.622 & 19.0 & 13.54 & 9.515 & 25.3 \\
\hline & & $p<=4$ & 2.692 & 1.893 & 12.3 & 2.692 & 1.893 & 12.3 \\
\hline \multirow[t]{5}{*}{ Japan } & \multirow[t]{5}{*}{7} & $p=0$ & $54.74 * *$ & $46.66^{* *}$ & 37.5 & $119.9 * *$ & $102.2^{* *}$ & 87.3 \\
\hline & & $p<=1$ & 30.65 & 26.13 & 31.5 & $65.21^{*}$ & 55.58 & 63.0 \\
\hline & & $p<=2$ & 22.39 & 19.09 & 25.5 & 34.56 & 29.45 & 42.4 \\
\hline & & $p<=3$ & 9.67 & 8.242 & 19 & 12.16 & 10.37 & 25.3 \\
\hline & & $p<=4$ & 2.493 & 2.125 & 12.3 & 2.493 & 2.125 & 12.3 \\
\hline \multirow[t]{5}{*}{ Kenya } & \multirow[t]{5}{*}{11} & $\mathrm{p}=0$ & $41.12^{*}$ & 32.42 & 37.5 & $117.2^{* *}$ & $92.41^{*}$ & 87.3 \\
\hline & & $p<=1$ & $32.79 *$ & 25.85 & 31.5 & $76.08^{* *}$ & 59.98 & 63 \\
\hline & & $p<=2$ & $27.11^{*}$ & 21.38 & 25.5 & $43.29^{*}$ & 34.13 & 42.4 \\
\hline & & $p<=3$ & 12.43 & 9.798 & 19 & 16.18 & 12.75 & 25.3 \\
\hline & & $p<=4$ & 3.749 & 2.956 & 12.3 & 3.749 & 2.956 & 12.3 \\
\hline \multirow[t]{5}{*}{ Malaysia } & \multirow[t]{5}{*}{3} & $p=0$ & $56.78^{* *}$ & $52.46^{* *}$ & 37.5 & $163^{* *}$ & $150.6 * *$ & 87.3 \\
\hline & & $p<=1$ & $46.42 * *$ & $42.88^{* *}$ & 31.5 & $106.3^{* *}$ & $98.16^{* *}$ & 63.0 \\
\hline & & $p<=2$ & $31.84^{* *}$ & $29.41^{*}$ & 25.5 & $59.83^{* *}$ & $55.28 * *$ & 42.4 \\
\hline & & $p<=3$ & $21.92^{*}$ & $20.25 *$ & 19.0 & $28^{*}$ & $25.86^{*}$ & 25.3 \\
\hline & & $p<=4$ & 6.074 & 5.611 & 12.3 & 6.074 & 5.611 & 12.3 \\
\hline \multirow[t]{4}{*}{ Uruguay } & \multirow[t]{4}{*}{4} & $p=0$ & $43.22 * *$ & $39.46 * *$ & 31.5 & $76.18^{* *}$ & $69.56^{*}$ & 63 \\
\hline & & $p<=1$ & 20.19 & 18.44 & 25.5 & 32.96 & 30.09 & 42.4 \\
\hline & & $p<=2$ & 10.75 & 9.818 & 19 & 12.77 & 11.66 & 25.3 \\
\hline & & $p<=3$ & 2.016 & 1.84 & 12.3 & 2.016 & 1.84 & 12.3 \\
\hline
\end{tabular}


Table A.4 - Cointegration Results: Lag Length Selection and Eigenvalue Statistics - EXTERNAL SECTOR

\begin{tabular}{|c|c|c|c|c|c|c|c|c|}
\hline & \multirow[b]{2}{*}{$\mid \begin{array}{c}\text { Selected System } \\
\text { Lag Length }\end{array}$} & \multirow[b]{2}{*}{$\begin{array}{c}\text { Ho: } \\
\text { Rank=p }\end{array}$} & \multicolumn{3}{|c|}{ Maximal Eigenvalue } & \multicolumn{3}{|c|}{ Eigenvalue Trace } \\
\hline & & & Statistic & $\begin{array}{l}\text { Statistic, } \\
\text { adjusted for } \\
\text { degrees of } \\
\text { freedom }\end{array}$ & $\begin{array}{l}95 \% \text { critical } \\
\text { value }\end{array}$ & Statistic & $\begin{array}{l}\text { Statistic, } \\
\text { adjusted for } \\
\text { degrees of } \\
\text { freedom }\end{array}$ & $\begin{array}{l}95 \% \text { critical } \\
\text { value }\end{array}$ \\
\hline \multirow[t]{3}{*}{ Chile } & \multirow[t]{3}{*}{5} & $\mathrm{p}=0$ & $43.49 * *$ & $39.9^{* *}$ & 25.5 & $68.51^{* *}$ & $62.86^{* *}$ & 42.4 \\
\hline & & $p<=1$ & $23.12^{*}$ & $21.21^{*}$ & 19 & 25.02 & 22.96 & 25.3 \\
\hline & & $p<=2$ & 1.905 & 1.748 & 12.3 & 1.905 & 1.748 & 12.3 \\
\hline \multirow[t]{5}{*}{ Colombia } & \multirow[t]{5}{*}{5} & $p=0$ & $57.93^{* *}$ & $50.54^{* *}$ & 37.5 & $129.9^{* *}$ & $113.3^{* *}$ & 87.3 \\
\hline & & $p<=1$ & 27.35 & 23.86 & 31.5 & $71.98 * *$ & 62.8 & 63 \\
\hline & & $p<=2$ & 21.24 & 18.53 & 25.5 & 44.63 & 38.94 & 42.4 \\
\hline & & $\mathrm{p}<=3$ & 17.03 & 14.86 & 19.0 & 23.38 & 20.4 & 25.3 \\
\hline & & $p<=4$ & 6.355 & 5.545 & 12.3 & 6.355 & 5.545 & 12.3 \\
\hline \multirow[t]{5}{*}{ Denmark } & \multirow[t]{5}{*}{12} & $p=0$ & $58.94^{* *}$ & $41.43^{*}$ & 37.5 & $140.5 * *$ & $98.74 * *$ & 87.3 \\
\hline & & $p<=1$ & $32.74^{*}$ & 23.01 & 31.5 & $81.52 * *$ & 57.31 & 63.0 \\
\hline & & $p<=2$ & $29.03^{*}$ & 20.4 & 25.5 & $48.78^{*}$ & 34.29 & 42.4 \\
\hline & & $p<=3$ & 17.83 & 12.54 & 19 & 19.76 & 13.89 & 25.3 \\
\hline & & $p<=4$ & 1.923 & 1.352 & 12.3 & 1.923 & 1.352 & 12.3 \\
\hline \multirow[t]{5}{*}{ Japan } & \multirow[t]{5}{*}{6} & $p=0$ & $79.87^{* *}$ & $69.76^{* *}$ & 37.5 & $167 * *$ & $145.9^{* *}$ & 87.3 \\
\hline & & $p<=1$ & $51.43^{* *}$ & $44.92^{* *}$ & 31.5 & $87.17 * *$ & $76.13^{* *}$ & 63.0 \\
\hline & & $p<=2$ & 22.23 & 19.41 & 25.5 & 35.74 & 31.21 & 42.4 \\
\hline & & $p<=3$ & 9.764 & 8.528 & 19.0 & 13.51 & 11.8 & 25.3 \\
\hline & & $p<=4$ & 3.747 & 3.273 & 12.3 & 3.747 & 3.273 & 12.3 \\
\hline \multirow[t]{5}{*}{ Kenya } & \multirow[t]{5}{*}{12} & $p=0$ & $46.41 * *$ & 35.7 & 37.5 & $123.8^{* *}$ & $95.22^{*}$ & 87.3 \\
\hline & & $\mathrm{p}<=1$ & $36.45^{*}$ & 28.04 & 31.5 & $77.38^{* *}$ & 59.52 & 63.0 \\
\hline & & $p<=2$ & 22.31 & 17.16 & 25.5 & 40.93 & 31.48 & 42.4 \\
\hline & & $p<=3$ & 13.46 & 10.36 & 19.0 & 18.62 & 14.32 & 25.3 \\
\hline & & $p<=4$ & 5.161 & 3.97 & 12.3 & 5.161 & 3.97 & 12.3 \\
\hline \multirow[t]{3}{*}{ Malaysia } & \multirow[t]{3}{*}{6} & $p=0$ & $42.77 * *$ & $39.19^{* *}$ & 25.5 & $64.94 * *$ & $59.51^{* *}$ & 42.4 \\
\hline & & $p<=1$ & 18.58 & 17.02 & 19 & 22.17 & 20.32 & 25.3 \\
\hline & & $p<=2$ & 3.592 & 3.291 & 12.3 & 3.592 & 3.291 & 12.3 \\
\hline
\end{tabular}


Table A.4 - Cointegration Results: Lag Length Selection and Eigenvalue Statistics - WAGES

\begin{tabular}{|c|c|c|c|c|c|c|c|c|}
\hline & & & & aximal Eigen & alue & & Eigenvalue $T r$ & race \\
\hline & $\begin{array}{c}\text { Selected System } \\
\text { Lag Length }\end{array}$ & $\begin{array}{c}\text { Ho: } \\
\text { Rank=p }\end{array}$ & Statistic & $\begin{array}{l}\text { Statistic, } \\
\text { adjusted for } \\
\text { dof }\end{array}$ & $\begin{array}{l}95 \% \text { critical } \\
\text { value }\end{array}$ & Statistic & $\begin{array}{l}\text { Statistic, } \\
\text { adjusted for } \\
\text { dof }\end{array}$ & $\begin{array}{l}95 \% \text { critical } \\
\text { value }\end{array}$ \\
\hline Chile & 4 & $\begin{array}{l}\mathrm{p}=0 \\
\mathrm{p}<=1 \\
\mathrm{p}<=2\end{array}$ & $\begin{array}{l}46.82^{* *} \\
15.15 \\
6.457\end{array}$ & $\begin{array}{l}43.73 * * \\
14.15 \\
6.032\end{array}$ & $\begin{array}{l}25.5 \\
19 \\
12.3\end{array}$ & $\begin{array}{l}68.42 * * \\
21.6 \\
6.457\end{array}$ & $\begin{array}{l}63.91 * * \\
20.18 \\
6.032\end{array}$ & $\begin{array}{l}42.4 \\
25.3 \\
12.3\end{array}$ \\
\hline Colombia & 2 & $\begin{array}{l}\mathrm{p}=0 \\
\mathrm{p}<=1 \\
\mathrm{p}<=2\end{array}$ & $\begin{array}{l}29.18^{*} \\
11.12 \\
4.939\end{array}$ & $\begin{array}{l}28.29 * \\
10.78 \\
4.787\end{array}$ & $\begin{array}{l}25.5 \\
19 \\
12.3\end{array}$ & $\begin{array}{l}45.24^{*} \\
16.05 \\
4.939\end{array}$ & $\begin{array}{l}43.85^{*} \\
15.56 \\
4.787\end{array}$ & $\begin{array}{l}42.4 \\
25.3 \\
12.3\end{array}$ \\
\hline Denmark & 13 & $\begin{array}{l}p=0 \\
p<=1 \\
p<=2\end{array}$ & $\begin{array}{l}26.88^{*} \\
23.31^{*} \\
0.392\end{array}$ & $\begin{array}{l}21.69 \\
18.81 \\
0.3163\end{array}$ & $\begin{array}{l}25.5 \\
19 \\
12.3\end{array}$ & $\begin{array}{l}50.59 * * \\
23.71 \\
0.392\end{array}$ & $\begin{array}{l}40.82 \\
19.13 \\
0.3163\end{array}$ & $\begin{array}{l}42.4 \\
25.3 \\
12.3\end{array}$ \\
\hline Japan & 13 & $\begin{array}{l}p=0 \\
p<=1 \\
p<=2\end{array}$ & $\begin{array}{l}94.87^{* *} \\
19.45^{*} \\
6.441\end{array}$ & $\begin{array}{l}79.26^{* *} \\
16.25 \\
5.381\end{array}$ & $\begin{array}{l}25.5 \\
19 \\
12.3\end{array}$ & $\begin{array}{l}120.8^{* *} \\
25.89^{*} \\
6.441\end{array}$ & $\begin{array}{l}100.9^{* *} \\
21.63 \\
5.381\end{array}$ & $\begin{array}{l}42.4 \\
25.3 \\
12.3\end{array}$ \\
\hline
\end{tabular}


TABLE A.5 - Dummy Variables Used in the Cointegration Analysis and Single Equation Estimations

\begin{tabular}{|c|c|c|c|}
\hline Country & Dummy Variable & Explanation for including the dummy & ummy is included in... \\
\hline Chile & $\begin{array}{l}\text { June- } 82 \\
\text { July-82 } \\
\text { September- } 84 \\
\text { October-84 } \\
\text { November-84 }\end{array}$ & $\begin{array}{l}\text { Dummy controls for exchange rate depreciation. } \\
\text { Dummy controls for exchange rate depreciation. } \\
\text { Dummy controls for exchange rate depreciation. } \\
\text { Dummy controls for exchange rate depreciation. } \\
\text { Following the September } 1984 \text { devaluation, the Central Bank } \\
\text { transferred significant amount of resources to commercial } \\
\text { banks. }\end{array}$ & $\begin{array}{l}\text { Monetary sector (MCI), labor } \\
\text { sector (WCI), and external } \\
\text { sector }(\mathrm{ECI}) \text { cointegration } \\
\text { analysis and the money }(\mathrm{M}) \\
\text { and price }(\mathrm{P}) \text { equations (eqn.) } \\
\mathrm{MCI}, \mathrm{WCI}, \mathrm{ECI}, \mathrm{M} \text {, and P eqn. } \\
\mathrm{MCI}, \mathrm{WCI}, \mathrm{ECI}, \mathrm{M} \text {, and } \mathrm{P} \text { eqn. } \\
\mathrm{MCI}, \mathrm{WCI}, \mathrm{ECI}, \mathrm{M} \text {, and } \mathrm{P} \text { eqn. } \\
\mathrm{MCI}, \mathrm{WCI}, \mathrm{ECI}, \mathrm{M} \text {, and } \mathrm{P} \text { eqn. } \\
\mathrm{P} \text { eqn. }\end{array}$ \\
\hline Colombia & $\begin{array}{l}\text { Centered Seasonals } \\
\text { Interacted Centered } \\
\text { Seasonals }\end{array}$ & $\begin{array}{l}\text { Needed to control for changes in wage seasonality occuring } \\
\text { after } 1990 \text {. } \\
\text { Needed to control for changes in wage seasonality occuring } \\
\text { after } 1990 \text {. }\end{array}$ & WCI and $\mathrm{P}$ eqn. \\
\hline Denmark & $\begin{array}{l}\text { DCOTAX } \\
\text { DUMCAPCON } \\
\text { Oct-77 } \\
\text { April-78 } \\
\text { May-78 } \\
\text { October-78 } \\
\text { August-80 } \\
\text { January-83 } \\
1983 \text { Q1 } \\
1983 \text { Q2 } \\
\text { April-86 } \\
\\
\text { 1992Q4 } \\
\text { December-92 } \\
\text { June-93 } \\
\text { July-93 } \\
\text { August-93 }\end{array}$ & $\begin{array}{l}\text { DVAT=3 for } 1977 \mathrm{Q} 4,2.25 \text { for } 1978 \mathrm{Q} 4 \text {, and } 1.75 \text { for } 1980 \mathrm{Q} 3 \\
\text { This dummy controls for three increases in the value-added tax } \\
\text { rate. } \\
\text { DPRSTOP= } 1 \text { for } 1978 \mathrm{Q} 4 \text {, for } 1979 \mathrm{Q} 1 \text {, for } 1979 \mathrm{Q} 4 \text {, and for } \\
1980 \mathrm{Q} 1 \text {. This dummy controls for } 4 \text { periods of price controls. } \\
\text { DCOTAX }=1 \text { for } 1979 \mathrm{Q} 3 \text {, and for } 1986 \mathrm{Q} 2 \text {. This dummy } \\
\text { controls for two cases of special commodity taxes. } \\
\text { DUMCAPCON=1 for } 1983(1) \text { through } 1998(2) \text {; zero } \\
\text { otherwise; it controls for the removal of capital controls. } \\
\text { Controls for unidentified data outlier. } \\
\text { Controls for unidentified data outlier. } \\
\text { Controls for unidentified data outlier. } \\
\text { Controls for unidentified data outlier. } \\
\text { Controls for unidentified data outlier. } \\
\text { Controls for unidentified data outlier. } \\
\text { Controls for the time it takes for country to adjust to lifting of } \\
\text { capital controls. } \\
\text { Controls for the time it takes for country to adjust to lifting of } \\
\text { capital controls. } \\
\text { Controls for pressures in the foreign exchange market which } \\
\text { led to a rise in long- and medium-term interest rates, starting in } \\
\text { the second quarter of } 1986 \text {. } \\
\text { Controls for speculative attacks in the last quarter of ' } 92 \text {. } \\
\text { Controls for speculative attacks. } \\
\text { Controls for speculative attacks. } \\
\text { Controls for speculative attacks. } \\
\text { Controls for speculative attacks. }\end{array}$ & $\begin{array}{l}\mathrm{MCI}, \mathrm{WCI}, \mathrm{ECI}, \mathrm{M} \text {, and } \mathrm{P} \text { eqn. } \\
\mathrm{MCI}, \mathrm{WCI}, \mathrm{ECI}, \mathrm{M} \text {, and } \mathrm{P} \text { eqn. } \\
\mathrm{MCI}, \mathrm{WCI}, \mathrm{ECI}, \mathrm{M} \text {, and } \mathrm{P} \text { eqn. } \\
\mathrm{MCI} \text { and } \mathrm{ECI} \\
\mathrm{P} \text { eqn. } \\
\mathrm{P} \text { eqn. } \\
\mathrm{P} \text { eqn. } \\
\mathrm{P} \text { eqn. } \\
\mathrm{P} \text { eqn. } \\
\mathrm{P} \text { eqn. } \\
\mathrm{MCI}, \mathrm{ECl}, \mathrm{M} \text {, and } \mathrm{P} \text { eqn. } \\
\mathrm{MCI}, \mathrm{ECl}, \mathrm{M} \text {, and } \mathrm{P} \text { eqn. } \\
\mathrm{P} \text { eqn. }\end{array}$ \\
\hline Japan & $\begin{array}{l}\text { Dmay } \\
\text { Dapril } \\
\text { April-89 } \\
\text { April-97 } \\
\text { DjulyT } \\
\text { DJuneT }\end{array}$ & $\begin{array}{l}\text { Dummy for May 1990, controlling for a shift from postal } \\
\text { savings into M2. } \\
\text { Dummy for April 1990, controlling for a shift from postal } \\
\text { savings into M2. } \\
\text { Dummy controls for VAT increase. } \\
\text { Dummy controls for VAT increase. } \\
\text { Dummy controls for bonus payments. } \\
\text { Dummy controls for bonus payments. }\end{array}$ & $\begin{array}{l}\mathrm{MCI}, \mathrm{M} \text {, and } \mathrm{P} \text { eqn. } \\
\mathrm{MCI}, \mathrm{M} \text {, and } \mathrm{P} \text { eqn. } \\
\mathrm{MCI}, \mathrm{WCI}, \mathrm{ECI}, \mathrm{M} \text {, ard } \mathrm{P} \text { eqn. } \\
\mathrm{MCI}, \mathrm{WCI}, \mathrm{ECI}, \mathrm{M} \text {, and } \mathrm{P} \text { eqn. } \\
\mathrm{WCI} \text { and } \mathrm{P} \text { eqn. } \\
\mathrm{WCI} \text { and } \mathrm{P} \text { eqn. }\end{array}$ \\
\hline
\end{tabular}

Notation: $\mathrm{MCI}, \mathrm{WCI}$, and ECI indicate that the corresponding dummy was allowed to enter unrestrictedly in the money, labor, and external sectors cointegration analysis, respectively. $\mathrm{M}$ and $\mathrm{P}$ indicate that the dummy entered the money and price equations, respectively. 
TABLE A.5 - Dummy Variables Used in the Cointegration Analysis and Single Equation Estimations

\begin{tabular}{|c|c|c|c|}
\hline Country & Dummy Variable & Explanation & Dummy is included in... \\
\hline Malaysia & $\begin{array}{l}\text { February-77 } \\
\text { March-77 } \\
\text { February-80 } \\
\text { July-81 } \\
\text { December-81 } \\
\text { March-85 } \\
\text { March-88 } \\
\text { May-91 } \\
\text { March-92 } \\
\text { June-92 } \\
\text { February-93 } \\
\text { March-93 } \\
\text { April-93 } \\
\text { June-93 } \\
\text { October-93 } \\
\text { January-94 } \\
\text { September-94 } \\
\text { January-84 } \\
\text { February-84 } \\
\text { March- } 84 \\
\text { November-82 } \\
\text { December-82 } \\
\text { January-90 } \\
\text { December-92 }\end{array}$ & $\begin{array}{l}\text { Controls for peak of } \mathrm{M} 2 \text { growth. } \\
\text { Controls for peak of } \mathrm{M} 2 \text { growth. } \\
\text { Controls for unidentified data outlier. } \\
\text { Dummy controls for drought. } \\
\text { Controls for sharp increases in prices due both to the drought } \\
\text { and to the upward adjustment in various administered prices. } \\
\text { Controls for first in a series of four adjustments in the central } \\
\text { exchange rate. } \\
\text { Dummy controls for tight monetary policy; Central Bank } \\
\text { launches an aggressive treasury bond sale program. } \\
\text { Controls for unidentified data outlier. } \\
\text { Controls for unidentified data outlier. } \\
\text { Controls for unidentified data outlier. } \\
\text { Controls for unidentified data outlier. } \\
\text { Dummy controls for devaluation. } \\
\text { Controls for sharp devaluation in the exchange rate as part of } \\
\text { macroeconomic policy adopted in April } 93 . \\
\text { Controls for unidentified data outlier. } \\
\text { Controls for strong foreign exchange inflows around October } \\
\text { 1993; also, exchange rate was unified on October } 17,1993 . \\
\text { Controls for accelerating inflation due to surge in monetary } \\
\text { aggregates, drought, and price liberalization. } \\
\text { Controls for unidentified data outlier. } \\
\text { Dummy controls for withdrawal of subsidies for fuel. } \\
\text { Dummy controls for withdrawal of subsidies for fuel. } \\
\text { Dummy controls for withdrawal of subsidies for fuel. } \\
\text { Dummy controls for peso float in late November 1982. } \\
\text { Dummy controls for sharp fall in peso value; as a result of the } \\
\text { float, the banking system experienced massive withdrawals of } \\
\text { foreign currency deposits. } \\
\text { Controls for debt-to-debt conversion scheme. } \\
\text { Controls for debt-to-debt conversion scheme. } \\
\text { Controls for unidentified data outlier. } \\
\text { Controls for unidentified data outlier. } \\
\text { Controls for unidentified data outlier. } \\
\text { Controls for unidentified data outlier. }\end{array}$ & 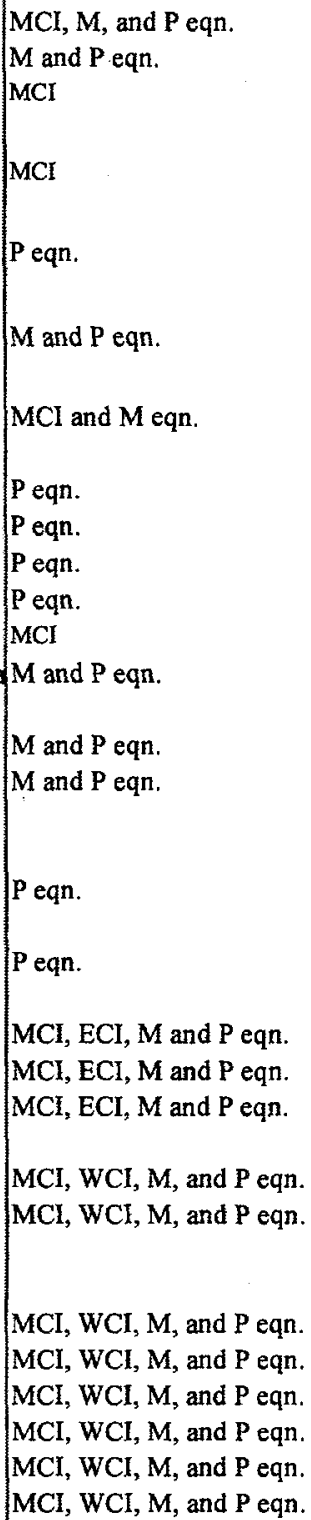 \\
\hline
\end{tabular}

Notation: $\mathrm{MCI}, \mathrm{WCI}$, and $\mathrm{ECI}$ indicate that the corresponding dummy was allowed to enter unrestrictedly in the money, labor, and external sectors cointegration analysis, respectively. $M$ and $P$ indicate that the dummy entered the money and price equations, respectively. 


\section{Policy Research Working Paper Series}

Title

$\begin{aligned} & \text { WPS2289 Exchange Rate Overvaluation and } \\ & \text { and Trade Protection: Lessons } \\ & \text { from Experience }\end{aligned}$
WPS2290 Decentralization and Corruption:
Evidence across Countries

WPS2292 Dividing the Spoils: Pensions, Privatization, and Reform

in Russia's Transition

WPS2293 Should Capital Flows be Regulated? A Look at the Issues and Policies

WPS2294 Reforming the Urban Water System in Santiago, Chile

WPS2295 Resolving Bank Failures in Argentina: Augusto de la Torre Recent Developments and Issues

WPS2296 An Ecological and Historical Perspective on Agricultural Development in Southeast Asia

WPS2297 Sources of Ethnic Inequality in Vietnam

Yujiro Hayami

WPS2298 Fiscal Deficits, Monetary Reform, and Inflation Stabilization in Romania

WPS2299 Household Savings in Transition Economies

WPS2300 Single Mothers in Russia: Household Strategies for Coping with Poverty

WPS2301 Identifying Welfare Effects from Subjective Questions
Author

Howard J. Shatz

David G. Tarr

Raymond Fisman

Roberta Gatti

Jérôme Foulon

Paul Lanoie

Benoît Laplante

Ethan B. Kapstein

Branko Milanovic

Roumeen Islam

Mary M. Shirley

L. Colin Xu

Ana Maria Zuluaga

Dominique van de Walle Dileni Gunewardena

Nina Budina

Sweder van Wijnbergen

Cevdet Denizer Holger C. Wolf

Yvonne Ying

Michael Lokshin

Kathleen Mullan Harris

Barry Popkin

Martin Ravallion

Michael Lokshin
Date

February 2000

February 2000

E. Khine 37471

February 2000

March 2000

P. Sader 33902

March 2000

March 2000

March 2000

March 2000

Contact for paper

L. Tabada 36896

Y. D'Souza 31449

R. Islam 32628

P. Sintim-Aboagye 38526

M. De Loayza 38902

P. Kokila 33716

March 2000

H. Sladovich 37698

March 2000

N. Budina 82045

March 2000

March 2000

P. Sader 33902

March 2000

P. Sader 33902
A. Cubukcu 38449 
Policy Research Working Paper Series

Title

WPS2302 Why Liberalization Alone Has Not Improved Agricultural Productivity

in Zambia: The Role of Asset

Ownership and Working Capital

Constraints

WPS2303 Malaria and Growth

WPS2304 Disinflation and the Supply Side
Author

Klaus Deininger

Pedro Olinto

F. Desmond McCarthy Holger Wolf

YiWu

Pierre-Richard Agénor Lodovico Pizzati
Date

March 2000

March 2000

March 2000
Contact for paper

M. Fernandez 33766

H. Sladovich 37698

T. Loftus 36317 